UNIVERSIDAD POLITÉCNICA DE MADRID

ESCUELA TÉCNICA SUPERIOR DE INGENIERÍA AGRONÓMICA, ALIMENTARIA Y DE BIOSISTEMAS

\title{
EFFECTS OF THE RESTRICTION OF
}

ACCESS TO FEED ON GROWTH PERFORMANCE AND THE

DEVELOPMENT OF THE PROXIMAL

PART OF THE GASTROINTESTINAL

TRACT IN YOUNG BROILERS

PhD THESIS

Guillermo Fondevila Lobera

Agricultural Engineer

2020 

DEPARTAMENTO DE PRODUCCIÓN AGRARIA ESCUELA TÉCNICA SUPERIOR DE INGENIERÍA AGRONÓMICA, ALIMENTARIA Y DE BIOSISTEMAS UNIVERSIDAD POLITÉCNICA DE MADRID

\title{
EFFECTS OF THE RESTRICTION OF ACCESS TO FEED ON GROWTH PERFORMANCE AND THE DEVELOPMENT OF THE PROXIMAL PART OF THE GASTROINTESTINAL TRACT IN YOUNG BROILERS
}

\author{
GUILLERMO FONDEVILA LOBERA
}

Agricultural Engineer

Supervised by

Gonzalo González Mateos (PhD, in Agricultural Engineering and Veterinary Sciences)

Escuela Técnica Superior de Ingeniería Agronómica, Alimentaria y de Biosistemas

Madrid, 2020 



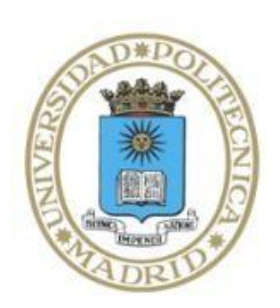

\section{UNIVERSIDAD POLITÉCNICA DE MADRID}

Tribunal nombrado por el Magfco. y Excmo. Sr. Rector de la Universidad Politécnica de Madrid, el día. de de 2020.

Presidente:

Vocal:

Vocal:

Vocal:

Secretario:

Suplente:

Suplente:

Suplente:

Realizado el acto de defensa y lectura de la Tesis el día de de 2020 en

la E. T. S. I. Agronómica, Alimentaria y de Biosistemas.

EL PRESIDENTE

LOS VOCALES

EL SECRETARIO 



\section{AGRADECIMIENTOS}

La finalización de esta Tesis Doctoral es el resultado del apoyo de muchas personas. En primer lugar, quiero agradecer y ensalzar la figura de mi tutor, Gonzalo G. Mateos. Su ayuda no se ha limitado a darme la oportunidad de realizar la Tesis, sino que durante estos años no he dejado de aprender de él y de su manera de trabajar y entender la investigación. Quiero agradecer a Gonzalo todo el apoyo y la confianza que ha depositado en mí desde el primer momento. Ha reforzado mi convencimiento de la importancia del esfuerzo y del trabajo en equipo. Gracias a él, estos cinco años no se han limitado a la consecución del objetivo de la Tesis, sino que han estado llenos de cursos, proyectos, colaboraciones con empresas y mucho aprendizaje. Me siento privilegiado.

Dar por terminada mi etapa como estudiante de Doctorado supone muchas cosas. Ha sido un camino largo pero, sobre todo, cargado de lecciones que me han hecho madurar, aprender y crecer. Cinco años han dado para mucho, y sería casi imposible intentar recordar a todas las personas con las que he compartido este camino. Año 2015, vuelvo a "la sala" con muchas ganas pero echando de menos todavía a mis compañeros de Casarrubios. Vuelvo tranquilo porque mis “jefas” Bea y Pilar siguen ahí, eso ayuda. De repente, la gran evasión. Se van ellas, se va Husham, se va Vahid. Quedamos Lourdes y yo. Llega Joan y pasa Baher. Llegan a la vez Jihed, Álvaro y Lewis, aunque no recuerdo el orden. Pasa mucha gente del Máster y también de R\&D (Nereida, David y Pepe). Cuando digo mucha gente, es mucha gente. Si a todo este pelotón le añadimos a Bernardo y a Rocco, que no están pero como si estuvieran, y los meses en Urbana-Champaign y Purdue... Y eso que únicamente hablo del "curro", he venido a hablar de mi libro. Agradezco a todos aquellos que me han ayudado y apoyado durante esta etapa que, más que un final, es otro comienzo. 
No puedo dejar de dedicar una parte muy especial de este apartado de agradecimientos a mis compañeros con los que más tiempo, del que denominan de hombro con hombro, he compartido. Dentro de esta lista destaca Lourdes, de quien he aprendido muchísimo. Ella me ha dado calma cuando más lo necesitaba y su ayuda no ha podido ser más importante. Por otro lado está Joan Lluís, con el que he compartido muchísimas horas al pie del cañón. Estoy seguro de que el apoyo mutuo que tanto nos ha dado, va a seguir aportándonos mucho en el futuro, tanto a nivel laboral como personal. Por último, quiero acordarme de Lewis y Álvaro, que llegaron como "panas” y que son unos trabajadores increíbles. Me han ayudado mucho, especialmente en estos últimos meses, y tienen un gran futuro por delante.

Dentro de unos años me preguntarán sobre cómo viví la crisis del Covid-19. Redacté mi Tesis Doctoral en unas circunstancias impensables y surrealistas que nos pusieron a prueba a todos. Un colapso general demasiado difícil de entender para aquellos que no lo vivieron. Tanto en estos momentos como en el pasado, el apoyo incondicional de mi familia, el más importante, ha sido fundamental. Desde que vine a Madrid, ellos siempre han apoyado cada decisión que he tomado y, posiblemente, no he sido capaz de agradecérselo lo suficiente. De Begoña, mi madre, he recibido siempre el cariño que necesitaba a pesar de la distancia. Ella me ayuda a restarle importancia a muchos problemas que, en realidad, no son tan importantes. Es la persona más fuerte que he conocido. De Manolo, mi padre, me quedo con su carácter y con el hecho de que, consciente o inconscientemente (no lo tengo claro), soy un reflejo de su forma de ser y es la razón por la que he seguido este camino. Él me dedicó su Tesis Doctoral en el año 1991, y yo le dedico la mía en 2020. Por último, la joya de la Corona, mi abuela Angelina. Me divierto tanto con ella que le considero un pilar fundamental. Sé que le hace muy feliz que haya otro Dr. Fondevila y lo celebraremos por todo lo alto cuando las circunstancias lo permitan. 


\section{INDEX OF CONTENTS}





\section{INDEX OF CONTENTS}

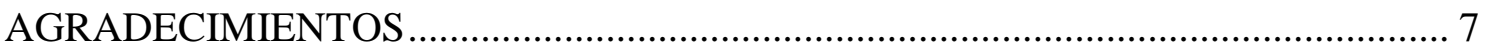

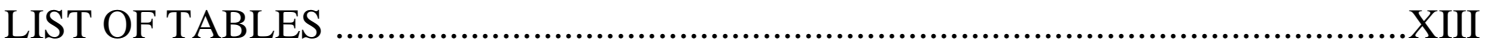

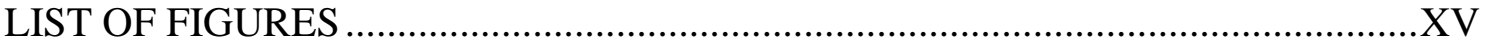

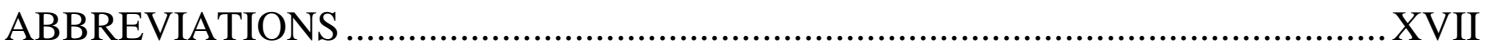

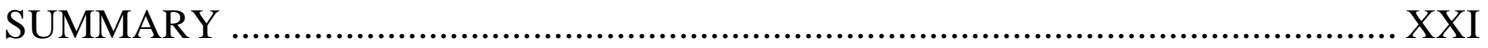

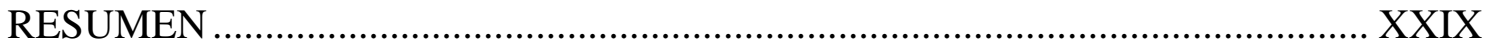

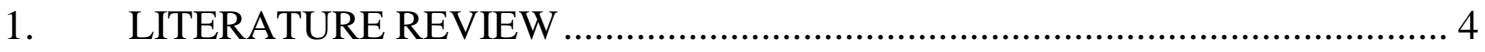

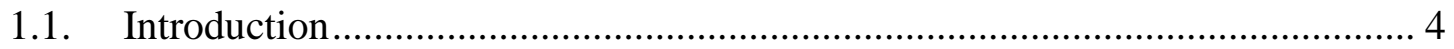

1.2. Modern broilers: genetic selection and bird health and welfare ....................... 5

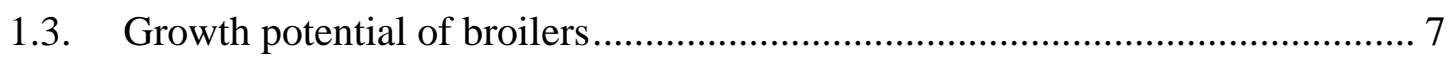

1.3.1. Early management practices after hatch ............................................... 7

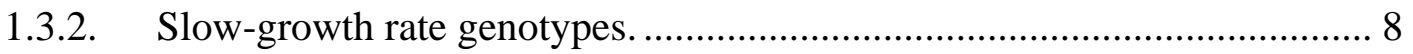

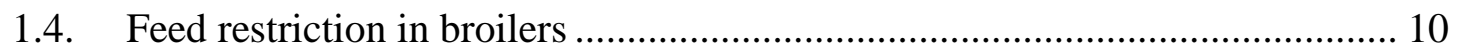

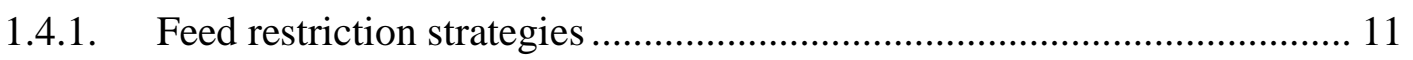

1.4.2. Effects of feed restriction on growth performance ............................... 12

1.4.3. Effects of feed restriction on broiler mortality and metabolic diseases ... 18

1.4.4. Effects of feed restriction on feeding behavior and gastrointestinal tract

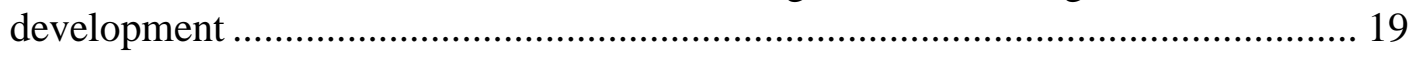

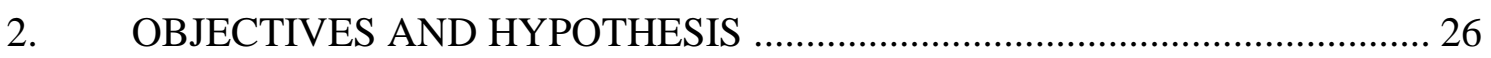

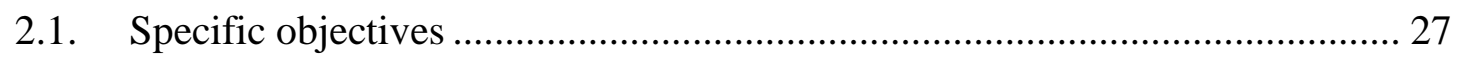

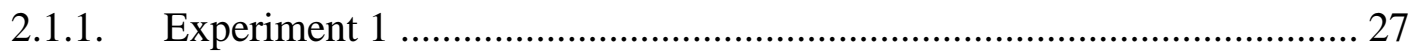

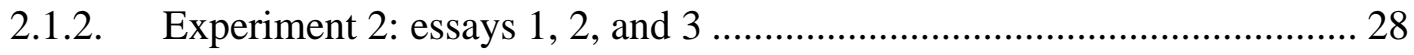

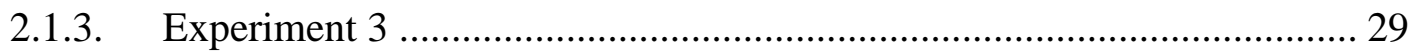

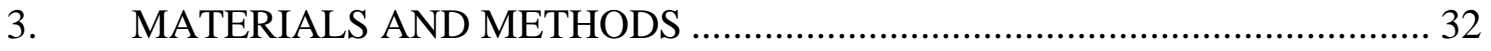

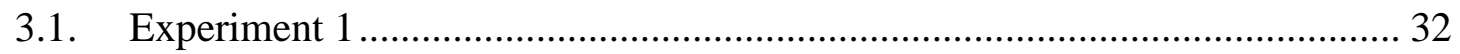

3.1.1. Bird husbandry, experimental design, and diet ................................. 32

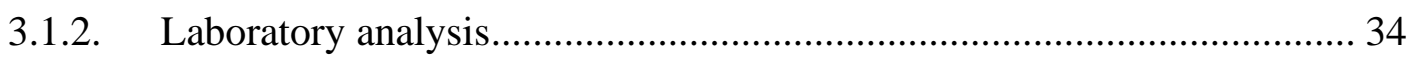

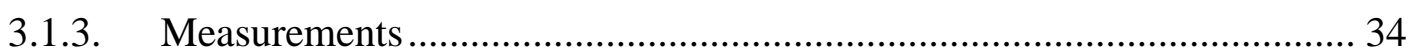

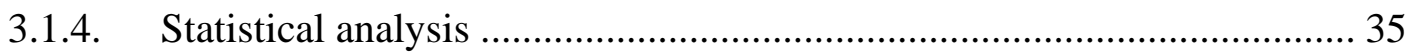

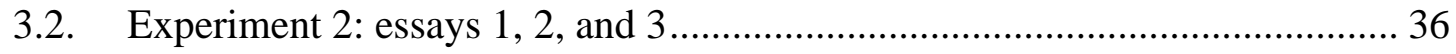

3.2.1. Bird husbandry, experimental design, and diet .................................. 36 


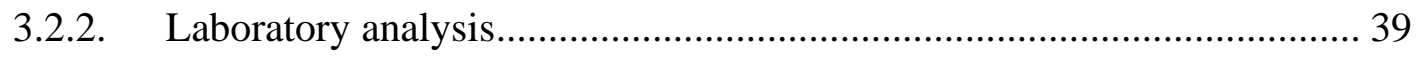

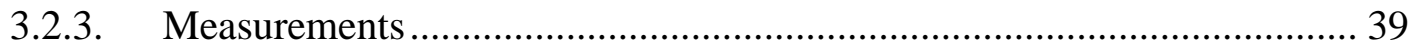

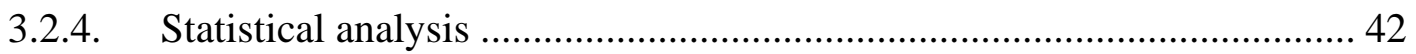

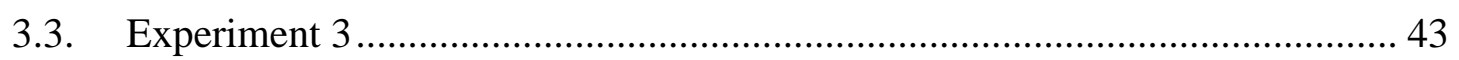

3.3.1. Bird husbandry, experimental design, and diet ................................. 43

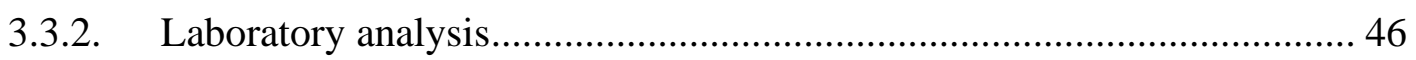

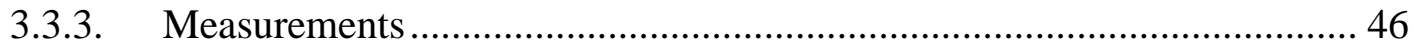

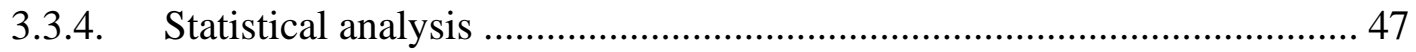

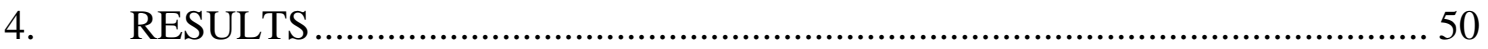

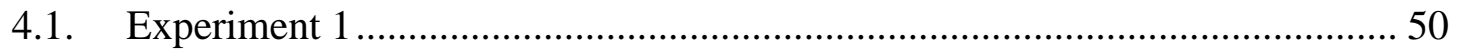

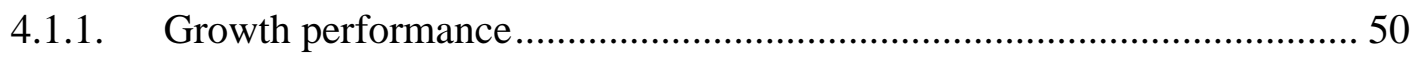

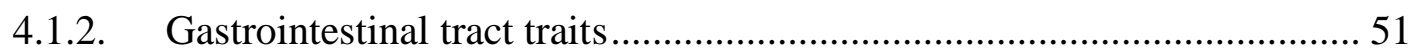

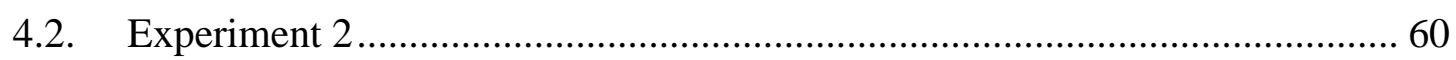

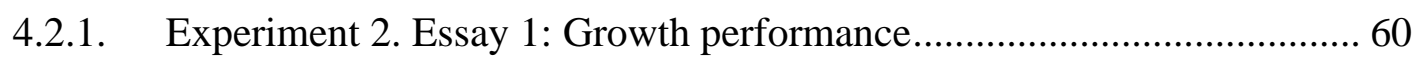

4.2.2. Experiment 2. Essay 2: Gastrointestinal tract traits............................... 60

4.2.3. Experiment 2. Essay 3: Digesta retention in crop and gizzard ................. 63

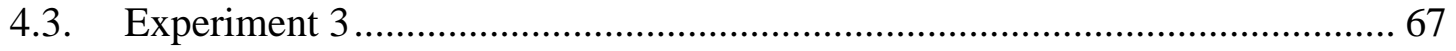

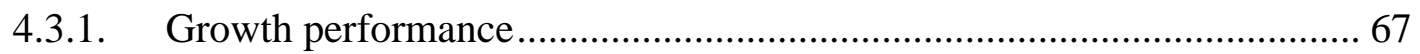

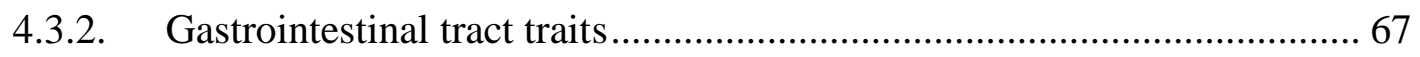

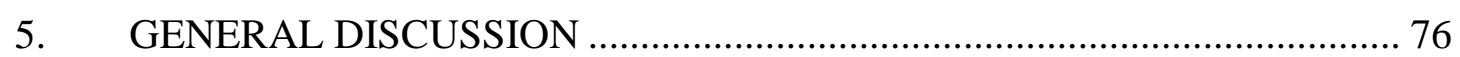

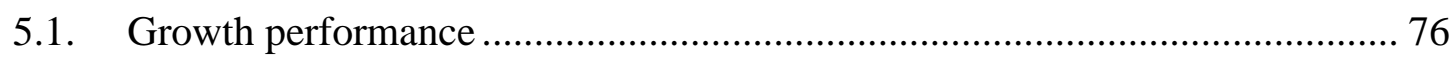

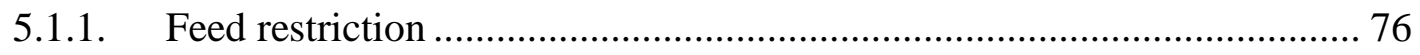

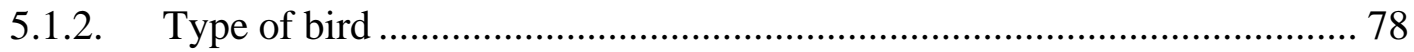

5.2. Feeding behavior and gastrointestinal tract traits .......................................... 79

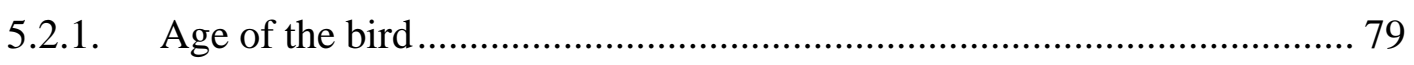

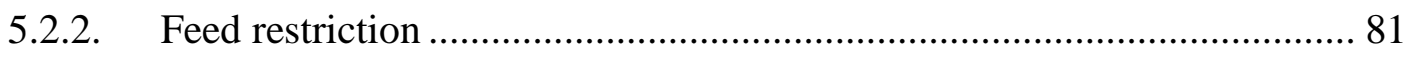

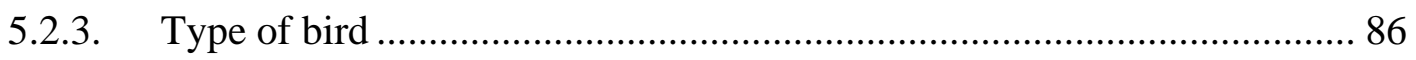

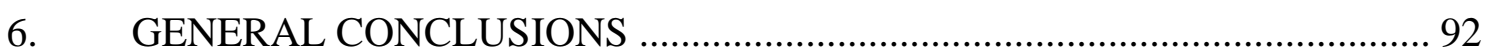

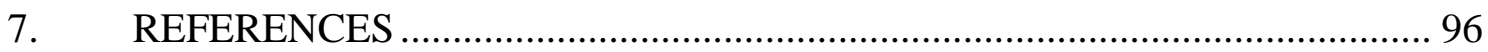




\section{LIST OF TABLES}

Table 1. Effects of the length of the feed restriction applied by the manipulation of the lighting program on broiler performance.

Table 2. Effects of the length of the feed restriction applied by the physical restriction of the access to feed on broiler performance compared to ad libitum feeding.

Table 3. Ingredient composition and chemical analysis of the experimental diet (\%). Experiments 1 and 2.

Table 4. Ingredient composition and chemical analysis of the experimental diet (\%). Experiment 3.

Table 5. Effects of the length of the fasting period on growth performance of broilers from 7 to $19 \mathrm{~d}$ of age ${ }^{1}$. Experiment 1. 50

Table 6. Effects of the length of the fasting period on selected crop traits. Experiment 1.

Table 7. Effects of the length of the fasting period on selected crop traits. Experiment 1.

Table 8. Effects of the length of the fasting period on selected gizzard traits. Experiment 1. 58

Table 9. Effects of the length of the fasting period on crop and gizzard $\mathrm{pH}^{1}$. Experiment 1 .

Table 10. Effects of the length of the fasting period on Lactobacillus spp. count (log cfu/g of digesta) in the crop content at 19 days of age. Experiment 1

Table 11. Effects of the length of the feed restriction period on broiler performance from 6 to $14 \mathrm{~d}$ of age $\mathrm{e}^{1,2}$. Experiment 2. Essay 1.

Table 12. Effects of training and length of the fasting period on selected crop and gizzard traits measured at $14 \mathrm{~d}$ of age, after $60 \mathrm{~min}$ of free access to feed ${ }^{1}$. Experiment 2 . Essay 2. 
Table 13. Effects of type of broiler and length of the feed restriction period ${ }^{1}(\mathrm{FR})$ on growth performance of broilers from 7 to 21 days of age ${ }^{2}$. Experiment 3 . 69

Table 14. Effects of type of broiler and length of the feed restriction period ${ }^{1}$ (FR) on the absolute (g) and relative (\% BW) weight of selected organs of the gastrointestinal tract at $21 \mathrm{~d}$ of age. Experiment 3 70

Table 15. Effects of type of broiler and length of the feed restriction period ${ }^{1}$ (FR) on the digesta content of the crop and the gizzard at $21 \mathrm{~d}$ of age. Experiment 3 71

Table 16. Effects of type of broiler and length of the feed restriction period ${ }^{1}$ (FR) on the Lactobacillus spp. count (log cfu/g of digesta), lactic acid concentration ( $\mu \mathrm{mol} / \mathrm{g}$ of digesta), and $\mathrm{pH}$ of the crop, and on gizzard $\mathrm{pH}$. Experiment 3. 72 


\section{LIST OF FIGURES}

Figure 1. Differences in body weight related to age of unselected strains since 1957 and 1978 compared to Ross 308 broilers (2005)

Figure 2. Growth performance observed in broilers from an unselected strain (1957) and Ross 308 (2001) fed either a representative 1957 or 2001 diet.

Figure 3. Effect of broiler strain on BW according to Cobb 500 (2018a), Hubbard JA757 (2016a), and Hubbard Redbro (2016b) performance objectives. Data correspond to expected values for as-hatched broilers fed a standard diet. 10

Figure 4. Description of the experimental treatments according to the fasting strategy used from 6 to $14 \mathrm{~d}$ of age ${ }^{1}$. Experiment 2. Essays 2 and 3. 38

Figure 5. Time schedule used for the measurements performed at $14 \mathrm{~d}$ of age to evaluate the effects of feed restriction on the digesta retention in crop and gizzard according to the fasting strategy used. Experiment 2. Essay 3.

Figure 6. Influence of age (means \pm SEM) on the weight of the empty crop and its content in absolute (a) and relative (b) terms. Mean values per age correspond to 48 observations (average of 4 treatments, corresponding to fasting periods of $0,4,6$, and $8 \mathrm{~h} / \mathrm{d}$, and 12 chicks per treatment and age). P-values in brackets correspond to data from the regression analysis $\left(\mathrm{L}=\right.$ Lineal; $\mathrm{Q}=$ Quadratic). Experiment $1^{1}$.

Figure 7. Influence of age (means \pm SEM) on the moisture $(\%)$ and dried $(\mathrm{g})$ content of the crop. Mean values per age correspond to 48 observations (average of 4 treatments, corresponding to fasting periods of $0,4,6$, and $8 \mathrm{~h} / \mathrm{d}$, and 12 chicks per treatment and age). $\mathrm{P}$-values in brackets correspond to data from the regression analysis ( $\mathrm{L}=$ Lineal; NS $=$ Not significant). Experiment $1^{1}$

Figure 8. Influence of age (means \pm SEM) on the weight of the empty gizzard and its content in absolute (a) and relative (b) terms. Mean values per age correspond to 48 observations (average of 4 treatments, corresponding to fasting periods of $0,4,6$, and 8 $\mathrm{h} / \mathrm{d}$, and 12 chicks per treatment and age). P-values in brackets correspond to data from the regression analysis $(\mathrm{L}=\mathrm{Lineal} ; \mathrm{Q}=\mathrm{Quadratic})$. Experiment $1^{1}$. 54 
Figure 9. Influence of age (means \pm SEM) on crop and gizzard $\mathrm{pH}$. Mean values per age correspond to 48 observations (average of 4 treatments, corresponding to fasting periods of $0,4,6$, and $8 \mathrm{~h} / \mathrm{d}$, and 12 chicks per treatment and age). P-values in brackets correspond to data from the regression analysis ( $\mathrm{L}=$ Lineal; $\mathrm{Q}=$ Quadratic; NS = Not significant $)$. Experiment $1^{1}$.

Figure 10. Influence of the length of the fasting period on the fresh content of the crop $(\% \mathrm{BW})$ in trained $(\mathrm{A})$ and non-trained $(\mathrm{B})$ birds at $14 \mathrm{~d}$ of age $(\mathrm{n}=6)$. Data measured 60 min after the start of the feeding period. P-values ( $\mathrm{L}=$ Linear; $\mathrm{Q}=\mathrm{Quadratic})$ correspond to data from the regression analysis. Experiment 2. Essay 2.

Figure 11. Influence of training (a) and length of the fasting period (b) on the fresh and dried content of the crop from 0 to $4 \mathrm{~h}$ after feed removal at $14 \mathrm{~d}$ of age. Data presented as mean values \pm SD per treatment. Experiment 2. Essay 3. 64

Figure 12. Influence of training (a) and length of the fasting period (b) on crop $\mathrm{pH}$ from 0 to $4 \mathrm{~h}$ after feed removal at $14 \mathrm{~d}$ of age. Data presented as mean values \pm SD per treatment. Experiment 2. Essay 3.

Figure 13. Influence of training (a) and length of the fasting period (b) on the fresh content of the gizzard (\% BW) from 0 to $4 \mathrm{~h}$ after feed removal at $14 \mathrm{~d}$ of age. Data presented as mean values \pm SD per treatment. Experiment 2. Essay 3 . 66

Figure 14. Influence of training (a) and length of the fasting period (b) on gizzard $\mathrm{pH}$ from 0 to $4 \mathrm{~h}$ after feed removal at $14 \mathrm{~d}$ of age. Data presented as mean values \pm SD per treatment. Experiment 2. Essay 3. 66 


\section{ABBREVIATIONS}

AL Ad libitum

AMEn Apparent metabolizable energy corrected for nitrogen

BW Body weight

EU-27 European Union

FCR Feed conversion ratio

FI Feed intake

FR Feed restriction

GIT Gastrointestinal tract

HPLC High-performance liquid chromatography

HW Hatching window

L Linear effect

NS Not significant

NTR Not trained to feed restriction

Q Quadratic effect

RW Relative weight

SD Standard deviation

SI Small intestine

TR Trained to feed restriction 
SUMMARY 


\section{SUMMARY}

Three experiments were conducted to evaluate the capacity of young broilers to adapt gastrointestinal tract (GIT) development to feed restriction (FR) programs, based on the physical restriction to the access to feed, and the effects on feeding behavior and growth performance. In experiment 1 , we studied the effects of the age of the birds and the length of the fasting period on growth performance, anticipatory feeding behavior, and the development of the proximal part of the GIT. In experiment 2, we evaluated the effects of the length of the FR period in the response of broilers with or without a previous training to fasting in terms of growth performance (essay 1), GIT development (essay 2), and the retention of the digesta in the proximal part of the GIT during the fasting period (essay 3). In experiment 3, we studied the effects of the length of the FR period on the development of the GIT and growth performance in broilers varying in growth potential.

In experiment 1, broilers were fed ad libitum (AL) from 1 to $6 \mathrm{~d}$ of age and then, fasted for $0,4,6$, or $8 \mathrm{~h}$ per day from 7 to $19 \mathrm{~d}$ of age. At 10,13,16, and $19 \mathrm{~d}$ of age, immediately before the start of the FR period, the development of the crop and gizzard were evaluated. The experimental design was completely randomized and the linear (L) and quadratic $(\mathbf{Q})$ effects of the length of the fasting period on feed intake (FI), body weight (BW) gain, feed conversion ratio (FCR), and GIT traits were determined. In addition, the effects of broiler age and the interactions with FR on GIT development were studied. From 7 to $19 \mathrm{~d}$ of age, FI (L, Q; $P<0.05)$ and BW gain $(\mathrm{L} ; P<0.01)$ decreased as the length of the FR period increased, with most of the differences observed from 7 to $13 \mathrm{~d}$ of age and with 6 or more hours of fasting. However, FCR was not affected by FR length. The relative weight of the crop $(\% \mathrm{BW})$ and its fresh content increased $(\mathrm{L} ; P<$ $0.001)$ and the moisture of the digesta $(\%)$ decreased $(\mathrm{L} ; P<0.001)$ as the fasting period increased. The dried content $(\mathrm{g})$ of the crop increased with FR, with most of the 
differences observed with 6 or more hours of fasting (L, Q; $P<0.001)$. At $19 \mathrm{~d}$ of age, the Lactobacillus spp. count in the crop increased (L; $P<0.05)$ with increases in the length of the FR period. Fasting did not affect any gizzard trait at any age. Physical restriction of the access to feed for $6 \mathrm{~h}$ or more reduced BW gain but did not affect FCR in broilers from 7 to $19 \mathrm{~d}$ of age. Feed restriction for 4 to $8 \mathrm{~h}$ stimulated FI in anticipation to the fasting conditions and increased crop development in broilers.

In experiment 2, three essays were conducted to evaluate the effects of FR on growth performance, GIT development, and the retention of the digesta in the proximal part of the GIT in broilers from 6 to $14 \mathrm{~d}$ of age. In essay 1, broilers were fed AL from 1 to $5 \mathrm{~d}$ of age and then, assigned at random to 4 treatments that consisted in applying a FR period of $0,4,6$, or $8 \mathrm{~h} / \mathrm{d}$ from 6 to $14 \mathrm{~d}$ of age. Fasting impaired FCR (L; $P<0.001)$ and reduced FI and BW gain (L, Q; $P<0.001)$. Most of the differences observed occurred in birds fasted for $6 \mathrm{~h}$ or more. In essay 2, 7 treatments were tested: a positive control group with birds fed AL throughout the experiment, and 6 extra groups organized as a $3 \times 2$ factorial with birds fasted for 4, 6, or $8 \mathrm{~h}$ under trained (TR, restricted access to feed daily from 6 to $14 \mathrm{~d}$ of age) or non-trained (NTR, restricted access to feed only on d 14) conditions. On d 14, after the end of the fasting period, all birds had free access to feed for $60 \mathrm{~min}$ and then, the crop and gizzard were examined. In relative terms (\% BW), the empty crop was heavier $(P<0.01)$ in the TR than in the NTR birds. The fresh digesta content of the crop increased with the length of the FR period $(\mathrm{L} ; P<0.001)$ with the greatest differences between the TR and the NTR groups being observed in birds under 4 h of fasting $(P<0.05$ for the interaction). Gizzard traits studied were not affected by treatment. In essay 3, the experimental design and all management conditions were similar to those indicated for essay 2. On d 14, immediately after the end of the fasting period, all birds were fed for $60 \mathrm{~min}$ and then the feed was removed. After feed removal, 
the empty weight, digesta content $(\% \mathrm{BW})$, and $\mathrm{pH}$ of the crop and gizzard were determined at one hour interval for the next $4 \mathrm{~h}$. The crop content increased with training $(P<0.05)$ and with the length of the fasting period $(P<0.001)$. However, independent of treatment, the effects of FR on crop content decreased with time and in fact, crop contents of all birds were negligible $3 \mathrm{~h}$ after feed removal $(P<0.001$ for the interaction with time). Gizzard content was greater $(P<0.05)$ in TR than in NTR birds for the first $2 \mathrm{~h}$ after feed removal but not thereafter $(P<0.05$ for the interaction with time). Crop $(P$ $<0.001)$ and gizzard $(P<0.05) \mathrm{pH}$ decreased with time after feed removal. In summary, fasting periods of $6 \mathrm{~h} / \mathrm{d}$ or more impaired broiler performance from 6 to $14 \mathrm{~d}$ of age. Crop content, measured $1 \mathrm{~h}$ after the end of the fasting period, increased with training and with the length of the FR. In addition, fasting increased the storage capacity of the crop and the retention time of the digesta in the proximal part of the GIT, effects that were more pronounced in trained birds and that increased with the length of the fasting period.

In experiment 3, the effects of the length of the FR on growth performance and on the development of the GIT were studied in broilers with high (Cobb 500) or medium (Hubbard JA757) growth potential, hatched over a hatching window (HW) of $24 \mathrm{~h}$ (Cobb24 and Hubbard-24, respectively). A third group of broilers from the same batch of Cobb 500 birds was used but the HW was of $48 \mathrm{~h}(\mathrm{Cobb}-48)$. Six treatments were organized as a $3 \times 2$ factorial with the 3 types of broilers and 2 fasting period lengths $(4$ vs. 8 h/d) applied from 7 to $21 \mathrm{~d}$ of age. All birds received a mash diet designed for slow-growth rate chickens. At $21 \mathrm{~d}$ of age, immediately after the end of their respective FR period, all birds had free access to feed for $60 \mathrm{~min}$ and the GIT was examined. No interactions between FR and broiler type were detected for any trait. From 7 to $21 \mathrm{~d}$ of age, the Cobb24 birds grew faster than the Cobb-48 birds and both faster than the Hubbard-24 birds ( $P$ $<0.001)$. The FCR weas similar for the Cobb-24 and the Cobb-48 birds and better for 
Cobb than for Hubbard birds $(P<0.001)$. Broilers fasted for $4 \mathrm{~h} / \mathrm{d}$ grew faster $(P<0.001)$ and had better FCR $(P=0.054)$ than broilers fasted for $8 \mathrm{~h} / \mathrm{d}$. The development of the organs of the GIT was not affected by broiler type, except for gizzard $\mathrm{pH}$ that was lower for the Cobb than for the Hubbard birds $(P<0.05)$. An increase in the FR period from 4 to $8 \mathrm{~h} / \mathrm{d}$ increased the weight and the contents of the crop $(P<0.001)$ and the number of Lactobacillus spp. colonies $(P<0.01)$. In summary, prolonged HW reduced the BW of the Cobb broilers but did not affect GIT development at $21 \mathrm{~d}$ of age. An increase in the fasting period from 4 to $8 \mathrm{~h} / \mathrm{d}$ reduced growth performance and increased the digesta content and Lactobacillus spp. counts of the crop of all birds, independently of their growth potential.

In summary, the physical restriction of the access to feed for $6 \mathrm{~h} / \mathrm{d}$ or more decreased FI in broilers for the first days after the implementation of the fasting strategy. The negative effects on growth performance observed during the period of adaptation to the FR strategy decreased with age and were not affected by broiler potential for growth. Fasting conditions changed broiler feeding behavior quickly with an increase in FI immediately before and after the absence of feed availability. In fact, birds anticipated their feeding behavior prior to the fasting period as soon as $3 \mathrm{~d}$ after the start of the FR strategy. The increase in the length of the FR period (from 0 to $8 \mathrm{~h} / \mathrm{d}$ ) stimulated the storage capacity of the crop and the retention time of the digesta in the proximal part of the GIT, an effect that was more intense in broilers with a previous training to fasting. Also, the number of colonies of Lactobacillus spp. in the crop increased with the length of the FR period. Fasting, however, had limited effects on gizzard development. In conclusion, fasting broilers for moderate periods of time (i.e., $6 \mathrm{~h}$ of darkness per day after $7 \mathrm{~d}$ of age), as proposed by the European Union, had limited influence on growth performance in young broilers, an effect that is expected to decrease or even disappear 
with age. The data confirm that independent of their growth potential, broilers are able to adapt rapidly their feeding behavior to the fasting conditions by stimulating the storage function of the crop before and after the FR period to compensate for the reduction in feed availability. 


\section{RESUMEN}




\section{RESUMEN}

La presente Tesis Doctoral está compuesta por tres experimentos cuyo objetivo principal es el estudio de los efectos de la adaptación de los pollos broiler a programas de restricción alimenticia (RA), basados en la restricción física del acceso al pienso, sobre el crecimiento, la conducta alimenticia y el desarrollo del tracto gastrointestinal (TGI) anterior. En el experimento 1, se estudiaron los efectos de la edad de los pollos y la duración del periodo de ayuno sobre el crecimiento, el consumo de pienso previo al ayuno y el desarrollo del TGI. En el experimento 2, se evaluó la influencia de un periodo de entrenamiento previo sobre la respuesta de los broilers a diferentes duraciones de ayuno sobre el crecimiento (ensayo 1), el desarrollo del TGI (ensayo 2) y el tiempo de retención de la digesta en el TGI anterior (ensayo 3). En el experimento 3, se estudiaron los efectos de la duración del periodo de RA sobre el crecimiento y el desarrollo del TGI en broilers con diferente potencial de crecimiento.

En el experimento 1, los pollos fueron alimentados ad libitum (AL) de 1 a $7 \mathrm{~d}$ de edad. De 7 a 19 d de edad, las aves fueron sometidas a 0, 4, 6 u 8 h diarias de RA. A los 10, 13, 16 y 19 d de edad, inmediatamente antes del periodo de ayuno, se evaluó el desarrollo y contenido del buche y la molleja. El diseño experimental fue completamente al azar y se estudió el efecto lineal $(\mathbf{L})$ y cuadrático $(\mathbf{Q})$ de la duración del periodo de ayuno y su interacción con la edad del ave sobre el consumo medio diario de pienso (CMD), la ganancia media diaria de penso (GMD), el índice de conversión (IC) y el desarrollo de los órganos. No se detectaron interacciones entre la edad y la duración del periodo de RA para ninguno de los parámetros estudiados. De 7 a 19 d de edad, el aumento en la duración del periodo de ayuno de 0 a 8 h/d disminuyó el CMD (L, Q; $P<$ 0.05) y la GMD (L; $P<0.01$ ), diferencias que fueron más evidentes de 7 a $13 \mathrm{~d}$ de edad y con 6 h o más de RA. Sin embargo, la duración del periodo de ayuno no afectó al IC. 
El peso relativo (PR, \% peso vivo) del buche y de su contenido fresco aumentó (L; $P<$ 0.001) y la humedad de la digesta $(\%)$ disminuyó $(\mathrm{L} ; P<0.001)$ con el aumento en la duración del periodo de ayuno. Además, el contenido seco (g) del buche aumentó con la duración de la RA, diferencias que fueron significativas con 6 o más horas del ayuno (L, Q; $P<0.001)$. A los $19 \mathrm{~d}$ de edad, las colonias de Lactobacillus spp. en el buche aumentaron $(\mathrm{L} ; P \leq 0.05)$ con la duración del periodo de RA. Periodos de ayuno de $6 \mathrm{~h}$ o más redujeron la GMD pero no afectaron al IC en broilers de 7 a 19 d de edad. El aumento de la duración de la RA de 4 a 8 h estimuló el consumo de pienso inmediatamente antes del periodo de ayuno y mejoró el desarrollo del buche de los broilers.

En el experimento 2, se realizaron tres ensayos para evaluar el efecto de la RA en broilers de 6 a 14 d de edad sobre el crecimiento, el de los órganos y la retención de la digesta en el tramo proximal del TGI. Todas las aves fueron alimentadas AL de 1 a $6 \mathrm{~d}$ de edad. En el ensayo 1, se aplicaron 0, 4, 6 y 8 h diarias de RA de 6 a 14 d de edad. El aumento en la duración del ayuno redujo el CMD y la GMD (L, Q; $P<0.001)$ y empeoró el IC (L; $P<0.001)$. En el ensayo 2, se aplicaron 7 tratamientos: un grupo control con pollos alimentados AL de 6 a 14 d de edad y 6 grupos experimentales organizados en un factorial $3 \times 2$ con 4, 6 y 8 h de RA aplicadas a pollos que fueron previamente entrenados (TR; con ayunos aplicados diariamente de 6 a 14 d de edad) o no entrenados (NTR; con ayunos aplicados únicamente el día 14 de vida) para afrontar los periodos de ayuno. Tras finalizar el periodo de ayuno a los $14 \mathrm{~d}$ de edad, todas las aves fueron alimentadas durante 60 min e inmediatamente después, el buche y la molleja fueron examinados. El PR del buche vacío fue superior en los pollos TR que en los NTR $(P<0.01)$. El contenido fresco del buche aumentó con la duración del ayuno (L; $P<0.001$ ), observándose las mayores diferencias entre los pollos TR y los NTR con periodos de $4 \mathrm{~h}$ de RA $(P<0.05$ para la 
interacción). En el ensayo 3, el diseño experimental y todas las condiciones de manejo fueron similares a las indicadas para el ensayo 2. A los $14 \mathrm{~d}$ de edad, tras acabar el periodo de ayuno, todas las aves fueron alimentadas durante 60 min e inmediatamente, se retiró el pienso de los comederos. Tras la retirada del pienso, el contenido, el peso y el pH del buche y de la molleja se analizaron en intervalos de una hora durante las siguientes $4 \mathrm{~h}$. El PR del contenido del buche aumentó con el entrenamiento $(P<0.05)$ y con la duración del ayuno $(P<0.001)$. Sin embargo, los efectos observados sobre el contenido del buche disminuyeron con el tiempo y, de hecho, el contenido del buche fue casi insignificante 3 h después de la retirada del pienso independientemente del ayuno aplicado $(P<0.001$ para la interacción con el tiempo). El contenido de la molleja disminuyó con el tiempo y fue superior en los pollos TR que en los NTR $(P<0.05)$ hasta 2 h después de la retirada del pienso, efecto que desapareció más adelante $(P<0.05$ para la interacción con el tiempo). El pH del buche $(P<0.001)$ y de la molleja $(P<0.05)$ disminuyó con el tiempo tras la retirada del pienso. En resumen, un periodo de ayuno de 6 h/d o más de 6 a $14 \mathrm{~d}$ de edad redujo el crecimiento de las aves y empeoró el IC. El contenido del buche, medido 1 h después de finalizar el periodo de ayuno, aumentó con el entrenamiento y con la duración de la RA. Además, el ayuno aumentó el tiempo de retención de la digesta en el TGI anterior, especialmente en los pollos previamente entrenados y con el aumento de la duración de la RA.

En el experimento 3, se estudiaron los efectos de la duración del periodo de RA sobre el crecimiento y el desarrollo del TGI en broilers seleccionados para crecimiento rápido (Cobb 500) o medio (Hubbard JA757). Los pollos fueron retirados de la nacedora tras una ventana de nacimientos (tiempo transcurrido desde la eclosión del primer huevo hasta la retirada de los pollos) de 24 h (Cobb-24 y Hubbard-24). Se utilizó un tercer grupo de pollos procedentes del mismo lote de Cobb 500 pero en los que la ventana de 
nacimientos fue de $48 \mathrm{~h}$ (Cobb-48). Todos los pollos fueron alimentados AL de 1 a $7 \mathrm{~d}$ de edad. De 7 a 21 d de edad, seis tratamientos se organizaron factorialmente como un 3 $\times 2$ con los tres tipos de broilers y dos duraciones del periodo de ayuno (4 vs. 8 h/d) aplicadas. Todas las aves recibieron una dieta experimental diseñada para pollos de estirpes de crecimiento lento. A los $21 \mathrm{~d}$ de edad, tras la finalización del periodo de ayuno, todos los pollos fueron alimentados durante 60 min y diferentes parámetros de los órganos del TGI fueron analizados. No se observaron interacciones entre los efectos principales para los parámetros estudiados. De 7 a 21 d de edad, los pollos Cobb-24 crecieron más que los pollos Cobb-48 y ambos más que los pollos Hubbard-24 $(P<0.001)$. El IC fue similar entre los pollos Cobb-24 y Cobb-48, pero los pollos Cobb mostraron mejor IC que los pollos Hubbard $(P<0.001)$. Las aves sometidas a un ayuno de $4 \mathrm{~h} / \mathrm{d}$ crecieron más $(P$ $<0.001)$ y tendieron a mostrar mejor IC $(P=0.054)$ que las sometidas a $8 \mathrm{~h} / \mathrm{d}$ de ayuno. El tipo de broiler tuvo un efecto limitado sobre el desarrollo de los órganos del TGI pero el pH de la molleja fue menor en los pollos Cobb que en los pollos Hubbard $(P<0.05)$. El aumento de la duración del periodo de ayuno de 4 a 8 h/d aumentó el peso $(P<0.001)$, el contenido $(P<0.001)$ y las colonias de Lactobacillus spp. $(P<0.01)$ del buche. Una prolongación de la ventana de nacimientos redujo el crecimiento de los pollos pero no afectó al desarrollo del TGI de los pollos a los 21 d de edad. El aumento de la duración del periodo de ayuno de 4 a 8 h/d aumentó el contenido y las colonias de Lactobacillus spp. del buche pero redujo el crecimiento de 7 a 21 d de edad de los pollos, independientemente de su potencial de crecimiento.

En resumen, periodos de restricción física del acceso al pienso de 6 h/d o más redujeron el CMD y la GMD de los pollos durante los primeros días tras la implantación del ayuno. Los efectos negativos asociados a la adaptación de los broilers a las condiciones de ayuno sobre los rendimientos productivos disminuyeron con la edad de 
las aves y fueron similares entre broilers con diferente potencial de crecimiento. La RA cambió rápidamente la conducta alimenticia de las aves con un aumento del consumo de pienso inmediatamente antes y después del periodo de ayuno. De hecho, el aumento en el consumo de pienso como anticipación al ayuno fue observable apenas tres días después de la implantación de la RA. El aumento de la duración del periodo de RA (de 0 a 8 h/d) estimuló la capacidad de almacenamiento del buche y la retención de la digesta en el TGI anterior, un efecto que fue más evidente en pollos previamente entrenados. Además, el incremento de la duración del ayuno aumentó el número de colonias de Lactobacillus spp. en el buche. Sin embargo, la RA tuvo un efecto limitado sobre el desarrollo y funcionalidad de la molleja. En conclusión, periodos moderados de RA, como las 6 h/d de oscuridad establecidas por la Unión Europea, tienen una influencia limitada sobre el crecimiento de los pollos, efecto que tiende a disminuir e incluso a desaparecer con la edad. Los broilers son capaces de adaptar rápidamente el consumo de pienso a las condiciones de ayuno mediante el aumento de la capacidad de almacenamiento del buche durante el periodo inmediatamente anterior y posterior a la RA para compensar la reducción en el tiempo de disponibilidad del alimento. 
LITERATURE REVIEW 


\section{LITERATURE REVIEW}

\subsection{Introduction}

In 2018, the global production of poultry meat was 95.5 Mt with United States of America, China, the European Union (EU-27), and Brazil as the main producers worldwide (FAO, 2020). Compared to other species, the short duration of the cycles in broiler production allows a fast response by the industry to market signals and facilitate improvements in genetics and feeding practices (Farrell, 2013). Poultry is considered as the most efficient production within the livestock sector in the use of raw materials and natural resources (Mottet and Tempio, 2017). Moreover, poultry is preferred to other productions in many regions worldwide as a cheap source of animal protein with a healthy image, limited environmental impact, and absence of religious limitations. Consequently, poultry production has a key role in providing protein sources to supply a global growing demand. Global meat production is expected to increase by $15 \%$ during the next decade with poultry being the fastest growing sub-sector, especially important in developing countries (OECD-FAO, 2018). Among other issues, the global poultry sector will face the increasing demand of protein sources and other concerns regarding food security, social challenges (poverty alleviation and equity), and environmental impact (Guèye, 1998; Hoffmann, 2005; Mottet and Tempio, 2017).

In the EU-27, poultry meat production is expected to expand by approximately $4 \%$ during the next decade (OECD-FAO, 2018). The consumption of poultry meat products grew rapidly in Europe during the past 50 years, reaching $15.2 \mathrm{~kg}$ per capita in 2017 (FAO, 2020). In fact, the poultry industry in the EU-27 is expected to grow further but through a slower pace for the next decade within a sector that will be challenged by several factors. Among these, fluctuations in feed cost and product prices, international 
relationships, a production chain free of antibiotics, new and reemerging avian diseases, environmental concerns, and emerging consumer demands must be highlighted (Van Horne and Achterbosch, 2008; Mottet and Tempio, 2017).

\subsection{Modern broilers: genetic selection and bird health and welfare}

Genetic selection during the last years has totally changed broiler production worldwide (Hunton, 2006). This selection has focused in searching for genotypes with faster growth rates, improved feed efficiency, and superior carcass yield (Rauw et al., 1998; Havenstein et al., 2003; Steenfeldt et al., 2019). In this respect, Zuidhof et al. (2014) reported that commercial broiler strains increased growth rate by over $400 \%$ with a $50 \%$ reduction in feed conversion ratio (FCR) from 1957 to 2005 (Figure 1).

The growth rate of modern birds depends at a great extent on their capacity to increase feed intake (FI) and to reach, through management practices, their maximum genetic potential (Richards, 2003; Ferket and Gernat, 2006; Mussini, 2012). Consequently, broilers are commonly fed pellet diets adapted to their high nutrient requirements and provided for ad libitum (AL) consumption to maximize FI and growth rate (Lewis and Morris, 2006; Lewis and Gous, 2007; Abdollahi et al., 2018). In this respect, Havenstein et al. (2003) compared the growth performance of an unselected broiler strain existing since 1957 and Ross 308 from 2001 fed either a representative 1957 or 2001 diet. The authors concluded that genetic selection contributed to $85-90 \%$ of the improvements observed in broiler performance over 45 years whereas nutrition was responsible for $10-15 \%$ of the changes (Figure 2). 
Figure 1. Differences in body weight related to age of unselected strains since 1957 and 1978 compared to Ross 308 broilers (2005).

Strain:

1957

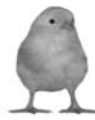

0 days:

28 days:

56 days:

Source: Zuidhof et al., 2014

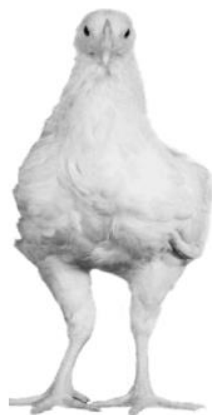

$905 \mathrm{~g}$

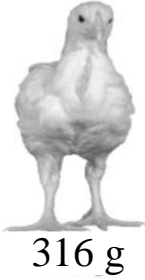

1978

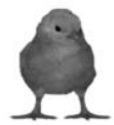

$42 \mathrm{~g}$
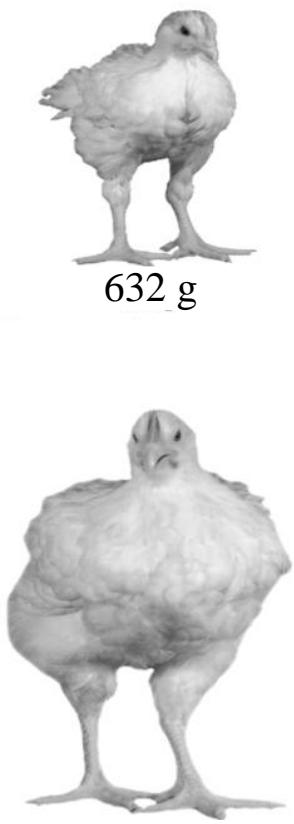

$1,808 \mathrm{~g}$
2005

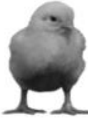

$44 \mathrm{~g}$
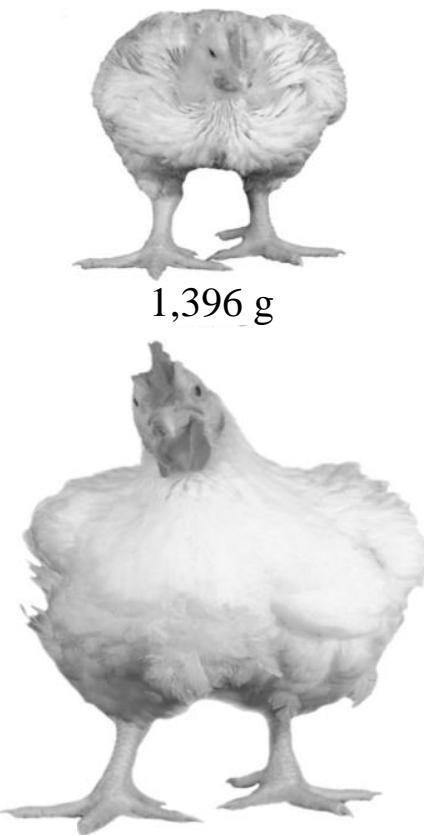

$4,202 \mathrm{~g}$

Figure 2. Growth performance observed in broilers from an unselected strain (1957) and Ross 308 (2001) fed either a representative 1957 or 2001 diet.
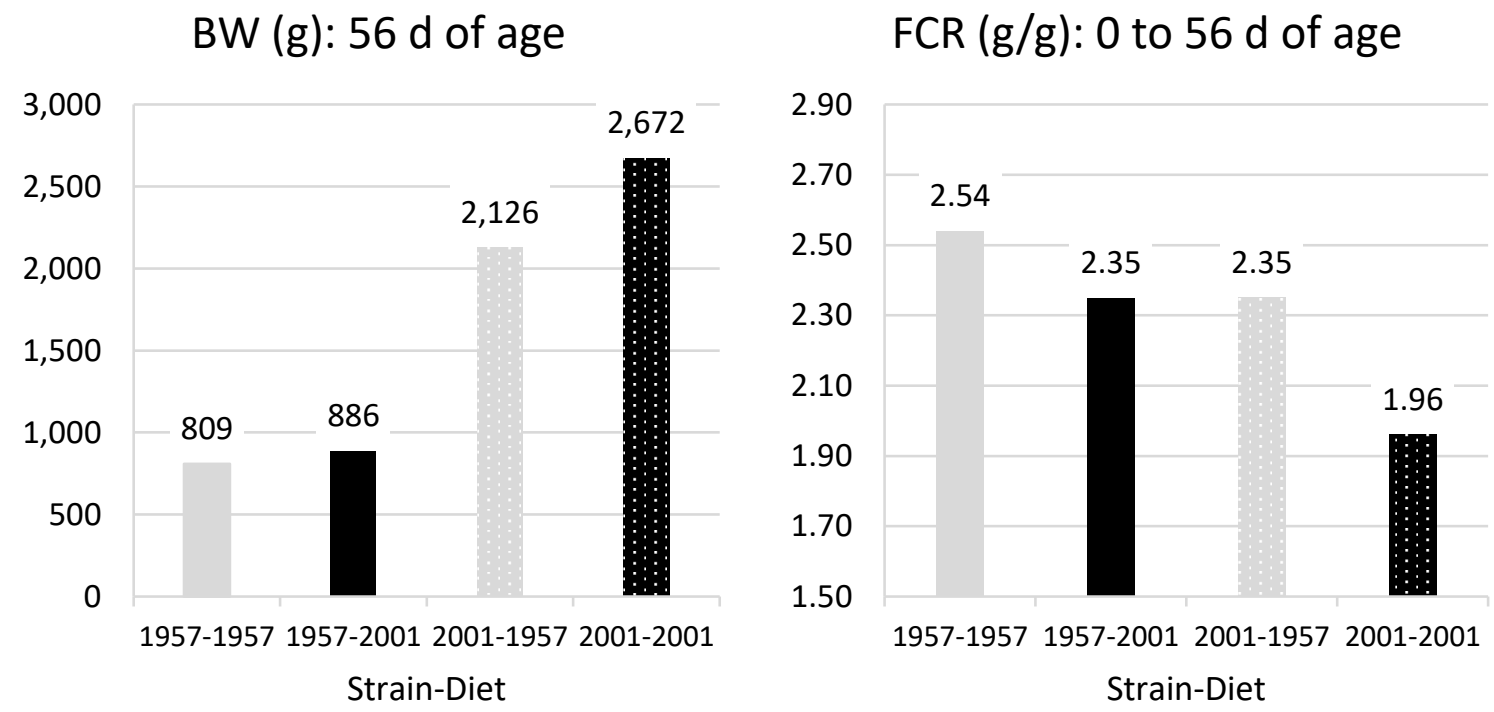

Source: Havenstein et al., 2003 
However, commercial practices such as AL pellet feeding are occasionally associated with negative impacts on overconsumption (Svihus and Hetland, 2001), poor nutrient digestibility (Svihus, 2010a, Serrano et al., 2013), and an increase in the incidence of mortality and enteric and metabolic diseases (Livingston et al., 2019). In order to reduce the incidence of problems associated with excessive growth and improve bird health and welfare, new strategies on feed management and formulation had become relevant in broiler production in the last years (Mateos et al., 2012; Rodrigues and Choct, 2018). In this respect, the European Commission agreed in 2007 a Directive to cover the welfare conditions in broiler production in the EU-27 (Council Directive 2007/43/EC). This Directive established commercial standards for improving the welfare of the birds as a response to the concerns of the consumers at the problems arising in intensive chicken farming (SCAHAW, 2000). Among others, the Directive set a maximum stocking density and conditions covering lighting, litter, feeding, and ventilation requirements.

\subsection{Growth potential of broilers}

\subsubsection{Early management practices after hatch}

The first hours of life of a broiler are crucial to optimize further growth and gastrointestinal tract (GIT) development (Uni and Ferket, 2004). Under commercial conditions, however, broiler management from hatch to placement in the farm is frequently inadequate. At the hatchery, chicks do not emerge from the eggs at the same time and hatch over a period that might range from 24 to 48 h (Careghi et al., 2005; Willemsen et al., 2010). In this respect, commercial hatcheries tend to extend the length of this period, also called hatching window $(\mathbf{H W})$, to maximize hatchability (Decuypere et al., 2001). As a result, early-hatched chicks remain in the setter under high temperatures until most of the chicks have hatched. Once the birds are removed from the setter, chicks 
are classified, vaccinated, and transported to the farm, remaining without access to feed and water for a period that in practice ranges from 48 to $72 \mathrm{~h}$ (Pinchasov and Noy, 1993; Noy and Sklan, 1999). A prolonged delay in eating and drinking activities is associated with stress, dehydration, weight loss, and poor development of the GIT which affect growth of the chicks and increase bird mortality (Jacobs et al., 2016; de Jong et al., 2017). In this respect, most studies on the effects of feed access after hatch reported that compared to early-fed birds, more than $48 \mathrm{~h}$ of delay in feeding and drinking after hatch reduced FI capacity and body weight $(\mathbf{B W})$ gain for the first weeks of life (Willemsen et al., 2010; de Jong et al., 2017). Furthermore, long periods of fasting after hatch compromise bird welfare with increased mortality rates and impaired immune system activation (de Jong et al., 2016).

\subsubsection{Slow-growth rate genotypes.}

The genetic selection of meat chickens has been focused in recent years on the search of birds with a fast potential for growth, increased carcass and breast meat yield, and improved feed efficiency (Rauw et al., 1998; Zuidhof et al., 2014). As a result, some unintended side effects are frequently observed under commercial conditions affecting overall broiler performance (Zuidhof et al., 2014). In this respect, physiological problems such as skeletal defects (Lilburn, 1994; Rath et al., 2000), metabolic disorders (Scheele, 1997; Olkowski, 2007), and altered immune function (Cheema et al., 2003) resulting from excessive growth rates can potentially affect broiler mortality and compromise animal welfare.

In most countries, fast-growth rate broilers are commonly bred under intensive systems to increase flock performance and maximize economic profitability (Mussini, 2012). However, in developed countries, the interest of the consumers in animal welfare 
issues has increased the demand of meat from slow- and medium-growth rate chickens (USDA-NASS, 2016; Augère-Granier, 2019). Slow growing strains are generally bred under free range and organic production systems to diversify broiler meat market and focus on other aspects different to price competitiveness (Bogosavljević-Bošković et al., 2012). In this respect, the establishment of quality standards (i.e., Organic, Certified, and Free Range production) during the past decades pushed geneticists to develop new genotypes to meet the requirements of specific labels and markets. Compared to fastgrowth rate broilers, these strains show lower BW gains and poorer FCR (Lewis et al., 1997: López and Leeson, 2005) and are usually associated to improvements in meat quality and bird welfare when reared under alternative production systems (Cömert et al., 2016). Ristić (2003) suggested that compared to broilers selected for rapid BW gain, slow-growth rate birds might need between 10 to 32 extra days to reach the same BW depending on strain. Differences in BW among a fast- (Cobb 500), a medium- (Hubbard JA757), and a slow- (Hubbard Redbro) growth rate strains according to expected results, are presented in Figure 3.

The development of alternative production systems and genetic selection for slower growth-rate strains are expected to increase during the next decade as a result of their increasing importance in the poultry meat market (Cömert et al., 2016). However, there is a lack of studies on nutrition and management practices in these strains and consequently, additional research is needed for the proper development of the sector. 
Figure 3. Effect of broiler strain on BW according to Cobb 500 (2018a), Hubbard JA757 (2016a), and Hubbard Redbro (2016b) performance objectives. Data correspond to expected values for as-hatched broilers fed a standard diet.

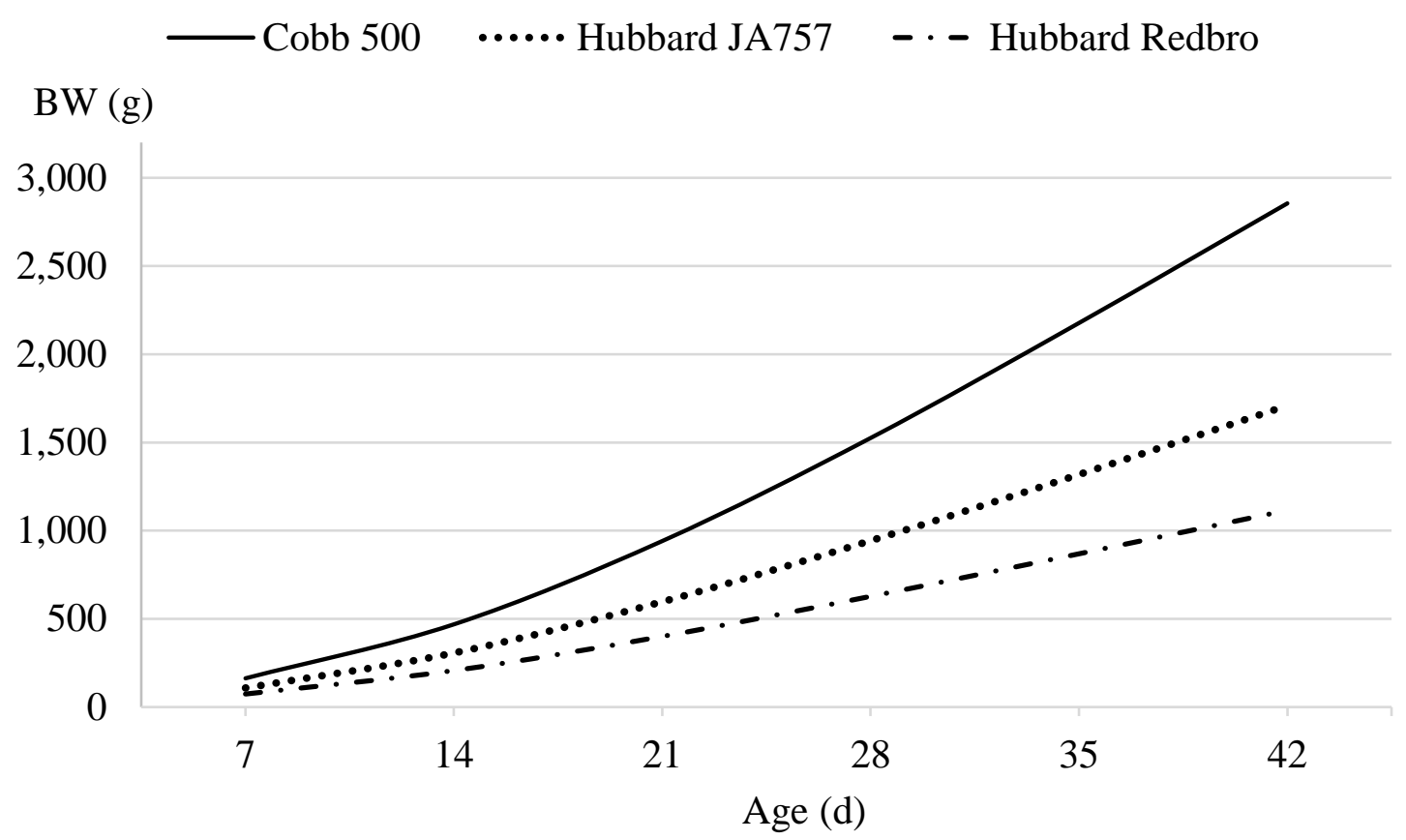

\subsection{Feed restriction in broilers}

Improvements in BW gain and feed efficiency have been the main objective of the broiler industry for the last 60 years with birds allowed to a continuous access to feed to maximize FI (Squibb and Collier, 1979; Classen, 1992). In the last decade, however, the interest of the consumers in issues such as sustainability, food safety, and welfare has questioned the importance of BW gain of broilers (Mateos et al., 2012). In this respect, excessive growth rates associated to AL feeding are frequently related to increased incidence of skeletal and metabolic diseases (Leeson et al., 1999; Lewis et al., 1996). Feed restriction (FR) strategies have been used to limit excessive growth early in life, improving at the same time bird health and welfare (Ballay et al., 1992; Sahraei, 2014). 


\subsubsection{Feed restriction strategies}

Feed restriction methods consist in limiting the nutrient availability for the birds by the manipulation of diet composition or by the reduction in the amount or time of the access to feed (Nielsen et al., 2003; Sahraei, 2014). In general, FR strategies can be classified into two main groups including qualitative and quantitative restriction methods.

1.4.1.1. Qualitative feed restriction. Feed restriction strategies conducted by limiting the nutrient content of the diet have been used to reduce the negative effects of excessive metabolic rates in broilers (Sahraei, 2012). In this respect, diet dilution by the inclusion of certain amounts of fiber (Mateos et al., 2019), the use of low protein and low energy diets (Leeson et al., 1996), and providing diets in mash instead of pellets (JiménezMoreno et al., 2016) decrease growth rates and improve the health status of the birds. These methods do not need any additional labor apart from modifying feed formulation or structure and consequently, they are easy to apply in practice.

1.4.1.2. Quantitative feed restriction. Feed intake can be limited in broilers by providing a certain amount of feed per day, frequently calculated to be close to the maintenance requirements of the birds (Plavnik and Hurwitz, 1985). However, the application of this strategy leads to practical problems in the calculations of feed consumption on a daily basis by weighing the birds regularly. Moreover, providing enough feeder space is necessary to avoid competition and prevent impairments in flock uniformity.

The reduction in time of feed availability by either the manipulation of the light program or by the physical restriction of the access to the feeders can be used to limit FI in broilers. The benefits of quantitative FR methods are associated to a reduction in the 
incidence of problems associated to excessive growth rates and improvements in feed efficiency (Olanrewaju et al., 2006; Sahraei, 2014). Broilers can be reared under continuous lighting or under dark-light schedules (Buyse et al., 1996). As diurnal animals, chickens eat regularly during the light period as long as there is no restriction in feeding availability or other environmental factors (Classen et al., 2016). During the dark period, however, FI is strongly reduced and therefore, intermittent light programs are associated with FR practices (Buyse et al., 1993; Lewis et al., 2009). Several factors, such as light intensity, feeder space, and stocking density interact with the lighting program modifying the effects of the lighting patterns on bird performance. On the other hand, FR practices implemented by the physical restriction of the access of the broilers to feeders might be of interest under certain conditions. For example, under hot weather conditions in opensided barns with limited capacity for environmental control, the period without artificial light should be controlled to maximize bird comfort. In these cases, the feed can be physically restricted during the heat of the day and left for free consumption at night to allow the birds to eat during the cooler hours (Soutyrine et al., 1998; Rambau et al. 2016; Farghly et al., 2018). This strategy is especially interesting in broilers genetically selected for fast-growth rates, which are especially sensitive to heat stress (Smith and Teeter, 1988; Özkan et al., 2003).

\subsubsection{Effects of feed restriction on growth performance}

The growing interest in animal welfare in most developed countries has contributed to the application of feeding practices based on the manipulation of the lighting program for broilers (Squibb and Collier, 1979; Classen, 1992). These management practices are frequently subjected to local legislation (Rodrigues and Choct, 2018). For example, the EU-27 (Council Directive 2007/43/EC) stipulates that after $7 \mathrm{~d}$ of age, broilers must have a minimum of $4 \mathrm{~h}$ of uninterrupted period of darkness (6 h in total) per day. Current 
legislation, aimed to improve welfare standards of the birds, has resulted in a concomitant reduction in the incidence of problems associated with excessive growth (Classen and Riddell, 1989; Brickett et al., 2007a; Livingston et al., 2019). Furthermore, management recommendations (Cobb, 2018b; Ross, 2018) suggest that 6 to 8 h of darkness can be used in commercial farms to improve growth performance and feed efficiency and reduce bird mortality.

Immediately after the implementation of a FR program to broilers, FI is frequently reduced because the capacity of the GIT is limited, resulting in a reduction in growth during the adaptation period to the new feeding strategy (Rodrigues and Choct, 2018). This effect is especially relevant in young birds, in which the capacity to increase FI to meet their high nutritional requirements is limited when time of feed availability is compromised. Consequently, FR practices starting earlier than $7 \mathrm{~d}$ of age might not be advisable (Plavnik and Hurwitz, 1985; Camacho et al., 2004). Previous research (Lewis et al., 2009; Schwean-Lardner et al., 2016; Farghly et al., 2019) have reported that the negative effects of FR on growth performance are especially evident during the period of adaptation to the fasting strategy. However, most of these studies do not report any numerical data on the impact of FR on FI and broiler growth during the first days after the implementation of the feeding strategy. In any case, the consistent disruption in growth performance observed for the first days after the start of the fasting period is often followed by a compensatory growth phase (Yu and Robinson, 1992) with a clear improvement in FCR (Camacho et al. 2004; Rodrigues and Choct, 2018). However, the effects of FR on growth performance depend on several factors such as the length of the fasting period, feed composition, stocking density, and the genotype, gender, and age of the birds (Buyse et al., 1996; Lien et al., 2007; Rambau et al., 2016). 
Fasting procedures based on the manipulation of the light program are easier to implement and manage than those based on the physical restriction of the access to feed (Sahraei, 2014; Rodrigues and Choct, 2018). Consequently, controlling light programs has been the preferred method to limit FI in broilers (Buyse et al., 1996; SchweanLardner et al., 2013; 2016). Results from various research on the effects of FR on growth performance and FI by the manipulation of the lighting program or by the physical restriction of the access to feed are presented in Tables 1 and 2, respectively. In most cases, the adaptation of broilers to FR resulted in a significant reduction in BW, a decrease that depended on the length of the fasting period (Lewis et al., 2009). Nevertheless, birds are frequently able to recover from the disruption in growth performance caused by FR, a recovery that varies with the severity of the FR strategy and with the period elapsed from the implementation of the FR strategy to slaughter (Butzen et al., 2013; Svihus et al., 2013; Dalal, 2016). In this respect, Lewis et al. (2009) reported that increasing the length of the dark period from 0 to $22 \mathrm{~h} / \mathrm{d}$ was negatively correlated with FI and BW gain during the first $21 \mathrm{~d}$ of age. At $35 \mathrm{~d}$ of age, however, no differences in growth performance were observed provided that the dark period was shorter than $18 \mathrm{~h} / \mathrm{d}$. Similarly, Schwean-Lardner et al. (2012) reported that the increase in the length of the dark period from 1 to $10 \mathrm{~h} / \mathrm{d}$ from 7 to $49 \mathrm{~d}$ of age resulted in similar BW at the end of this period. Other strategies such as the application of short intervals of light and dark periods by intermittent lighting programs have been studied resulting often in greater BW at market age and improvements in feed efficiency (Buyse et al., 1996; Onbaşilar et al., 2007; Svihus et al., 2013). In broilers subjected to physical restriction of the access to feed, a FR period of $12 \mathrm{~h} / \mathrm{d}$ under a 24 -h of continuous lighting program, reduced $\mathrm{BW}$ of the birds at $21 \mathrm{~d}$ of age but the differences disappeared at $42 \mathrm{~d}$ of age (Farghly et al., 2019). Probably, the poor growth performance observed with long fasting 
periods applied to young broilers resulted from the limited capacity of the birds to increase FI to overcome the reduction in feed availability (Schwean-Lardner et al., 2016). However, the information provided suggests that broilers adapt to fasting conditions with age, and that the initial reduction in FI could result in similar growth performance, if sufficient time is allowed for the adaptation of the birds to the FR strategy. In this respect, the negative impact of FR on growth performance is particularly relevant in birds processed at younger ages. Under these circumstances, birds might not have enough time to adapt their feeding behavior to the fasting strategy with the reductions in BW resulting from the shorter feeding period being more pronounced. 
Table 1. Effects of the length of the feed restriction applied by the manipulation of the lighting program on broiler performance.

\begin{tabular}{|c|c|c|c|c|c|c|}
\hline \multirow[b]{2}{*}{ Age of the birds } & \multirow[b]{2}{*}{$\begin{array}{l}\text { Feed restriction } \\
(\mathrm{h} / \mathrm{d})\end{array}$} & \multirow[b]{2}{*}{ Initial BW disruption } & \multicolumn{3}{|c|}{ Difference vs. control (\%) } & \multirow[b]{2}{*}{ Reference } \\
\hline & & & Feed intake & $\mathrm{BW}$ gain & FCR & \\
\hline \multirow[t]{9}{*}{2 to 35 days $^{1}$} & 3 & Yes & +4.9 & +1.4 & +3.2 & Lewis et al. (2009) \\
\hline & 6 & Yes & +3.2 & +0.5 & +2.4 & \\
\hline & 9 & Yes & +1.1 & +1.4 & -0.2 & \\
\hline & 12 & Yes & -0.5 & +0.9 & -1.2 & \\
\hline & 14 & Yes & -1.1 & -1.4 & +0.3 & \\
\hline & 16 & Yes & +0.3 & -0.9 & +1.4 & \\
\hline & 18 & Yes & +0.3 & -1.4 & +3.1 & \\
\hline & 20 & Yes & -6.5 & -9.0 & +3.1 & \\
\hline & 22 & Yes & -9.7 & -11.3 & +2.2 & \\
\hline \multirow[t]{3}{*}{7 to 38 days $^{2}$} & 4 & Not specified & +0.7 & +0.2 & +0.6 & Schwean-Lardner et al. (2012) \\
\hline & 7 & Not specified & -0.5 & -1.0 & +0.3 & \\
\hline & 10 & Not specified & -5.4 & -1.8 & -2.8 & \\
\hline \multirow[t]{3}{*}{7 to 49 days $^{2}$} & 4 & Not specified & +4.0 & +3.2 & -0.7 & \\
\hline & 7 & Not specified & +1.5 & +3.1 & +0.1 & \\
\hline & 10 & Not specified & -0.2 & +0.9 & -1.3 & \\
\hline
\end{tabular}

Abbreviations: BW, body weight; FCR, feed conversion ratio

${ }^{1}$ Birds from the control group were kept under $24 \mathrm{~h} / \mathrm{d}$ of light period

${ }^{2}$ Birds from the control group were kept under $23 \mathrm{~h} / \mathrm{d}$ of light period 
Table 2. Effects of the length of the feed restriction applied by the physical restriction of the access to feed on broiler performance compared to ad libitum feeding.

\begin{tabular}{|c|c|c|c|c|c|c|}
\hline \multirow[b]{2}{*}{ Age of the birds } & \multirow[b]{2}{*}{$\begin{array}{l}\text { Feed restriction } \\
(\mathrm{h} / \mathrm{d})\end{array}$} & \multirow[b]{2}{*}{ Initial BW disruption } & \multicolumn{3}{|c|}{ Difference vs. ad libitum (\%) } & \multirow[b]{2}{*}{ Reference } \\
\hline & & & Feed intake & $\mathrm{BW}$ gain & FCR & \\
\hline 28 to 42 days & 6 & Yes & +2.4 & -7.0 & +10.1 & Özkan et al. $(2003)^{1,2}$ \\
\hline 35 to 42 days & 6 & No & +12.1 & +8.9 & +2.9 & \\
\hline \multirow[t]{3}{*}{7 to 14 days } & 3 & Yes & -23.1 & -21.2 & -3.1 & El-Sagheer and Makled $(2005)^{2}$ \\
\hline & 6 & Yes & -25.6 & -28.8 & +3.1 & \\
\hline & 9 & Yes & -4.6 & -12.3 & +7.1 & \\
\hline \multirow[t]{3}{*}{7 to 49 days } & 3 & Yes & -7.8 & -2.3 & -2.2 & \\
\hline & 6 & Yes & -11.4 & -0.9 & -2.7 & \\
\hline & 9 & Yes & +3.6 & -1.3 & +5.8 & \\
\hline 1 to 21 days & 4 & Yes & -12.5 & -14.4 & +5.6 & Zhan et al. $(2007)^{3}$ \\
\hline \multirow[t]{2}{*}{7 to 35 days } & 8 & Yes & -10.7 & -10.3 & -0.5 & Rambau et al. (2016) \\
\hline & 12 & Yes & -22.1 & -19.7 & -2.8 & \\
\hline 1 to 21 days & 12 & Yes & -1.5 & -8.3 & +7.0 & Farghly et al. (2019) \\
\hline 1 to 42 days & 12 & Yes & -1.8 & -2.0 & +1.8 & \\
\hline
\end{tabular}

Abbreviations: BW, body weight; FCR, feed conversion ratio

${ }^{1}$ All birds were kept under a 23 -h light program

${ }^{2}$ Broilers at high environmental temperatures

${ }^{3}$ Slow-growth rate broilers 
The transition from a feeding regimen based on FR to AL feeding has been widely studied in broilers to induce a compensatory growth effect (Plavnik and Hurwitz, 1985; Ballay et al., 1992; Camacho et al. 2004). In this respect, Zhan et al. (2007) reported that broilers fasted for $4 \mathrm{~h} / \mathrm{d}$ from hatch to $21 \mathrm{~d}$ of age showed a $14 \%$ reduction in BW compared to broilers fed AL. After this period, all the birds were fed AL and the negative effects of FR on growth performance disappeared once the birds were able to recover from the disruption in growth rate. Similarly, Camacho et al. (2004) reported that broilers fasted for $8 \mathrm{~h} / \mathrm{d}$ from 7 to $21 \mathrm{~d}$ of age and then fed AL had similar BW at $49 \mathrm{~d}$ of age compared to birds fed AL throughout the experiment. In most cases, the change from a period of FR to AL feeding improved FCR at the end of the rearing period. These improvements have been attributed to a reduction of the metabolic requirements, a delay on the start of fat deposition, and a reduction in physical activity and heat production (Ketelaars et al., 1986; Apeldoorn et al., 1999; Ohtani and Leeson, 2000). However, the magnitude of the recovery of the birds varies with age and with the severity and duration of the FR conditions (Sahraei, 2012).

\subsubsection{Effects of feed restriction on broiler mortality and metabolic diseases}

Excessive growth rates associated to AL feeding in broilers have been frequently related to an increase in the incidence of skeletal disorders, leg abnormalities (Classen and Riddell, 1989; Classen, 1992), and metabolic problems such as ascites (Lott et al., 1996), sudden death syndrome (Brickett et al., 2007a; Lewis et al., 2010), and wooden breast (Livingston et al., 2019). In this respect, current legislation in the EU-27 (Council Directive 2007/43/EC) stablished a minimum of hours of darkness to be provided to broilers aiming to reduce these problems and improve bird health and welfare. 
As a result of genetic selection, modern broilers have developed a reduced cardiopulmonary capacity in relation to their high bone, organ, and muscle mass demands and consequently, some metabolic disorders might emerge (Olkowski, 2007; Buzala et al., 2015). However, a temporary decrease in growth rate during the first stages of life by the application of a FR program might alleviate the incidence of mortality in this birds (Teeter et al., 1987; Robinson et al., 1992; Olanrewaju et al., 2015). Probably, the lower metabolic requirements as well as the reduction of the initial skeletal loadings resulting from a slower initial growth contributed to the improvement in overall liveability (Schwean-Lardner et al., 2012; 2013). Also, in experiments conducted under tropical or heat stress conditions, the restriction of the access to feed during the heat of the day resulted in lower mortality rates by decreasing body temperature and heat production (Leeson, 1986; Özkan et al., 2003; El-Sagheer and Makled, 2005).

1.4.4. Effects of feed restriction on feeding behavior and gastrointestinal tract development

Feeding patterns in poultry depend on several factors such as bird strain, physiological status, and age as well as the composition and form of the diet and other environmental factors (Denbow, 1989; Savory, 1980, 1999; Richards, 2003). Typically, the feeding behavior of broilers fed AL consists in short and frequent approaches to the feed with little utilization of the crop as a storage organ (Buyse and Decuypere, 2003). In this respect, Svihus et al. (2013) reported that broilers ate small amounts of feed every 30 min when left with AL access to feed. In these birds, most feed particles do not enter in the crop and the digesta passes rapidly to the proventriculus and gizzard (Chaplin et al., 1992; Savory, 1985). However, the adaptation of broilers to FR results often in a fast adjustment of their feeding behavior to the lack of access to feed. Broilers subjected to 
different lengths of fasting increase their FI during the feeding period to compensate for the shorter period of feed availability (Shynkaruk et al., 2019). Lewis et al. (2009) reported that the feeding rate $(\mathrm{g} / \mathrm{h})$ during the light period increased as the length of the dark period increased from 0 to $14 \mathrm{~h} / \mathrm{d}$. Nevertheless, the increase in FI during the day was proportionally less evident when longer fasting periods were applied, reducing FI and compromising broiler growth.

The adaptation of broilers to FR results frequently in an increase in FI prior to the start (Shynkaruk et al., 2019; Schwean-Lardner et al., 2014) and immediately after the end (May and Lott, 1994; Svihus et al., 2010b) of the fasting period with changes in the anatomy and physiology of the GIT. A relevant consequence of this strategy is the change of the location of storage of the digesta in the GIT with a greater development and utilization of the crop (May and Lott, 1994; Svihus et al., 2013). In this respect, long periods of FR induce an anticipatory FI effect and increase the retention time of the digesta in the proximal part of the GIT (Buyse and Decuypere, 2003). Buyse et al. (1993) reported that the content of the crop increased by 10.5 -fold immediately before the start of the fasting period in broilers at $32 \mathrm{~d}$ of age kept under $10 \mathrm{~h} / \mathrm{d}$ of darkness. Also, Duve et al. (2011) reported that prior the start of the dark period, broilers subjected to $8 \mathrm{~h} / \mathrm{d}$ of darkness stored in the crop approximately $75 \%$ of their nocturnal energy requirements. This information suggests that broilers are able to predict the subsequent lack of feed availability (Cutler et al., 2005; Schwean-Lardner et al., 2014; Shynkaruk et al., 2019). In fact, if the capacity of the crop to store feed during fasting is sufficient, FI immediately after the end of the FR period might not be increased, suggesting that the birds were able to cover their nutrient requirement in the absence of feed availability (Scanes et al., 1987). However, the ability of the birds to predict a subsequent fasting period depends on the 
length of the FR and their adaptation with time to the new feeding strategy (Rodrigues and Choct, 2018). In broilers exposed to increasing lengths of darkness (from 4 to $10 \mathrm{~h} / \mathrm{d}$ ) from 7 to $27 \mathrm{~d}$ of age, substantial amounts of feed were stored in the crop during the last hour before the start of the dark period (Shynkaruk et al., 2019). In broilers exposed to 1 $\mathrm{h}$ of dark period, however, this anticipatory feeding behavior was not observed. Other research suggested that $4 \mathrm{~h}$ of fasting were not enough to stimulate the storage function of the crop prior to the FR period, an effect that was only observed when the fasting period lasted for $7 \mathrm{~h}$ or more (Schwean-Lardner et al., 2013, 2014; Dalal, 2016).

The mechanisms that regulate FI in poultry are varied and comprise complex processes controlled by the central nervous system, the GIT system, and the peripheral tissues (Richards et al., 2010). Feed consumption in broilers depends on several factors including those related to the diet (nutrient composition and feed structure) and management conditions including feed and water availability, environmental conditions, and health status. The gizzard is the main organ of the GIT of poultry that controls FI by regulating the flow of the digesta from the crop (Svihus, 2011; Mateos et al., 2019). In this respect, the filling of the gizzard controls appetite and regulates the rate of passage of the digesta through the different segments of the GIT. The crop of the birds, however, has a minor role in FI regulation in AL fed birds but plays an essential function in feed storage and moistening in birds kept under fasting conditions (Classen et al., 2016).

The crop of the birds is a walled diverticulum of the esophagus with an innervated and vascularized structure (Classen et al., 2016). Crop walls are able to distend through longitudinal folds on their inner surface in order to store the feed particles, a mechanism that is controlled by the filling of the gizzard (Chaplin et al., 1992; Jackson and Duke, 1995). In this respect, when the gizzard is full, the feed is stored in the crop and then 
slowly released to the following sections of the GIT (Rodrigues and Choct., 2018). Otherwise, the feed is barely retained in the crop and transported directly to the proventriculus. Shires et al. (1987) reported that in broilers fed AL under 24 h of light, the retention time of the digesta in the crop was approximately 7.4 min, exhibiting a low utilization of the crop as a storage organ. In contrast, birds subjected to fasting conditions learnt to accumulate considerable amounts of feed in their crops to cope with the lack of feed availability during the FR (May and Lott, 1994; Svihus et al., 2013). As a result of the modification of the feeding pattern, the storage capacity of the crop as well as the retention time of the digesta in this organ increases with the length of the fasting period (Buyse et al., 1993; Buys et al., 1998; Schwean-Lardner et al., 2013). In this respect, Dalal (2016) reported that the weight of the crop and its content increased as the length of the FR increased from 1 to $9 \mathrm{~h} / \mathrm{d}$. Similar results were observed by Shynkaruk et al. (2019) in broilers kept under fasting periods ranging from 1 to $10 \mathrm{~h} / \mathrm{d}$.

Inside the crop, the digesta is gradually moistened and subjected to the action of saliva and microbial population (Svihus, 2010b). In this respect, the crop plays an important role in the activation of exogenous enzymes during the moistening of the feed with potential improvements in further digestion (Bomba et al., 2006; Svihus, 2014). However, the environment of the crop is variable and depends at a great extent on the feed and water characteristics ( $\mathrm{pH}$, buffering capacity, feed additives, fiber content, and particle size) and on the retention time of the digesta (Cutler et al., 2005; Jozefiak et al., 2006; Fonseca et al., 2010).

The crop of the birds presents a substantial microbial activity which is particularly rich in lactic acid bacteria, with other bacteria such as enterococci and coliforms in smaller amounts (Bowen and Waldroup, 1969; Fuller 1973, 1977). The amount and 
diversity of the microbial population in the crop is mainly influenced by diet composition (Pritchard, 1972; Philips and Fuller, 1983) but also by variations in the retention time of the digesta in this organ (Cutler et al., 2005; Gabriel et al., 2006). In fact, longer retention times in the crop increase significantly the population of commensal bacteria, especially Lactobacillus spp. (Hinton et al., 2000a; Byrd et al., 2001). In this respect, Dalal (2016) reported that the number of colonies of Lactobacillus spp. in the crop increased as the length of the fasting period increased from 1 to $11 \mathrm{~h} / \mathrm{d}$, resulting in a subsequent production of lactic acid and short chain fatty acids (Tannock, 2004; Cutler et al., 2005; Hilmi et al., 2007). These fermentation products are associated to a reduction in digesta $\mathrm{pH}$ and influence the colonization of other bacteria in the crop and further segments of the GIT (Fuller and Brooker, 1974; Hinton et al., 2000b). In fact, the crop environment is considered as the first defense barrier against pathogenic bacteria such as Salmonella and Campylobacter (Corrier et al., 1999a,b; Tannock, 2004; Hilmi et al., 2007). This information suggests that FR practices might benefit nutrient digestion and GIT health by increasing the proportion of the feed that enters in the crop and the amount of time it spends there. 


\section{OBJECTIVES AND HYPOTHESIS}




\section{OBJECTIVES AND HYPOTHESIS}

Genetic selection in broilers has been focused for the last 50 years in searching for genotypes with fast growth, improved feed efficiency, and greater carcass yield (Rauw et al., 1998; Zuidhof et al, 2014). In order to meet these objectives, birds were allowed a continuous access to feed to maximize FI and increase flock profitability (Squibb and Collier, 1979; Classen, 1992). However, these practices are occasionally associated with negative impacts on nutrient digestibility (Svihus et al., 2010b, Serrano et al., 2013) and in an increase in the incidence of metabolic problems (e. g. ascites and lameness) and mortality (Leeson et al., 1999; Brickett et al., 2007b; Serrano et al., 2012; Livingston et al., 2019).

Feed restriction based on the manipulation of the light program or by the physical restriction of access to feed are alternatives to limit excessive growth early in life, improving health and welfare standards of the birds (Lewis et al., 2009; Rodrigues and Choct, 2018). In this respect, a minimum of $6 \mathrm{~h}$ darkness per day is mandatory in the EU27 (Council Directive 2007/43/EC) for broilers after 7 d of age. Under fasting conditions, broilers modify their feeding behavior with changes in the anatomy and physiology of the different organs of the GIT (Buyse et al., 1993; Svihus et al., 2013; Shynkaruk et al., 2019). However, long fasting periods are associated with reductions in BW gains, especially during the first days after the implementation of the fasting strategy, probably due to the limited capacity of broilers to meet their high nutritional requirements when time for feed availability is compromised (Lien et al., 2007). The impairments in growth performance depend on the length and conditions of the fasting period applied (Lewis et al., 2009; Rodrigues and Choct, 2018) but the information available on the early adaptation of broilers to moderate periods of FR, as those proposed by the EU-27, is scarce. 
The general objective of this Doctoral Thesis was to study the capacity of young broilers to adapt GIT development to programs based on the physical restriction of access to feed and its effects on feeding behavior and growth performance. The main hypothesis of this research was that the early adaptation of the broilers to fasting could depend on the length of the FR period and that the response of the birds might vary with age, previous training, and potential for growth.

\subsection{Specific objectives}

\subsubsection{Experiment 1}

Fasting procedures based on the manipulation of the light program are easier to implement and manage than the physical restriction of access to feed. Consequently, most of the research on the effects of the adaptation of the broilers to FR has been conducted modifying the light program (Buyse et al., 1996; Duve et al., 2011; Schwean-Lardner et al., 2013; 2016). However, limited information is available on the effects of physical restriction to access to feed, while maintaining unchanged the light program, on the development of the proximal part of the GIT of the birds.

The objective of this experiment was to evaluate the adaptation with time of the GIT development of modern broilers to moderate periods of physical restriction of the access to feed and its effects on feeding behavior and growth performance from 7 to $19 \mathrm{~d}$ of age. The hypothesis tested was that the response to fasting of broilers under a continuous 24-h lighting program could vary with time after the implementation of the fasting strategy and with the length of the FR period. Furthermore, it was hypothesized that broilers under moderate periods of physical restriction of the access to feed could increase FI prior to the start of the FR period, a potential adaptive mechanism to cope 
with the FR strategy, as observed in previous research conducted by the modification of the light program.

\subsubsection{Experiment 2: essays 1, 2, and 3}

Under practical conditions, the FR period not always can be programmed (i.e., late arrival of the new batch of feed to the farm, feed withdrawal during thinning of the flocks, unexpected hot waves). Consequently, broilers face the lack of feed availability without any previous training. The authors have not found any published research comparing the effects of the presence or absence of a previous training to the lack of access to feed on broiler response. The objective of this experiment was to evaluate the response of broilers to training on moderate periods of physical restriction of the access to feed from 6 to 14 d of age in terms of growth performance, development of the proximal part of the GIT, and the retention of the digesta in the crop and gizzard.

2.1.2.1. Experiment 2. Essay 1. The first hypothesis of this experiment was that the response of broilers under a continuous 24-h lighting program, to physical restriction to the access to feed during the first week after the implementation of the FR strategy could vary according the length of the fasting period, confirming results from experiment 1.

2.1.2.2. Experiment 2. Essay 2. The second hypothesis of the experiment was that the storage capacity of the crop, a potential adaptive mechanism of the bird to cope with the FR strategy, after a period without access to feed could increase with the length of the FR period. Furthermore, it was hypothesized that training on fasting could increase the response of the birds to fasting in terms of crop and gizzard function and development to face successfully for the lack of feed availability.

2.1.2.3. Experiment 2. Essay 3. The third hypothesis of the experiment was that a previous training of the birds on fasting could increase the retention time of the digesta 
in the organs of the proximal part of the GIT to face successfully a period of FR. Furthermore, the response of broilers in terms of storage capacity and digesta retention in the crop and the gizzard during the lack of feed availability could increase with the length of the FR period.

\subsubsection{Experiment 3}

The perception of the consumers on animal welfare issues have increased the demand for meat from slow- and medium-growth rate chickens in developed countries (USDA-NASS, 2016; Augère-Granier, 2019). On a separate issue, under commercial conditions, early-hatched chicks remain in the setter for long periods, often over $24 \mathrm{~h}$ (Willemsen et al., 2010). After removal from the setter, the birds are conveniently processed and transported to the farm, a period in which they continue without access to feed or water. A delay in eating and drinking activities is associated with stress, dehydration, weight loss, and poor development of the GIT which affects the growth of the chicks for the first weeks of life (Careghi et al., 2005; Jacobs et al., 2016).

The objective of this research was to evaluate the response of broilers with different potential for growth, to FR periods of 4 or $8 \mathrm{~h} / \mathrm{d}$ in terms of growth performance and GIT development from 7 to $21 \mathrm{~d}$ of age. It was hypothesized that the detrimental effects of longer fasting periods on FI, could be intensified in birds with a low potential for growth. Also, it was hypothesized that a reduction in FI capacity associated to the genetic background of the chicks, or to a delay in the access to feed and water after hatch because of prolonged HW, could affect the development and the storage capacity of the main organs of the proximal part of the GIT. 
MATERIALS AND METHODS 


\section{MATERIALS AND METHODS}

The procedures used in this research were approved by the Animal Ethics Committee of the Universidad Politécnica de Madrid (PROEX 030/16) and were in compliance with the Spanish Guidelines for the Care and Use of Animals in Research (Boletín Oficial del Estado, 2013).

\subsection{Experiment 1}

\subsubsection{Bird husbandry, experimental design, and diet}

In total, 312 straight-run Ross 308 broilers, weighing $44.5 \pm 0.75 \mathrm{~g}$ at the arrival to the experimental station, were randomly allotted to 24 cages $(100 \times 45 \times 40 \mathrm{~cm})$ in groups of 13. The cages (Alternative Design, Siloam Springs, AR) were equipped with 2 low pressure nipple drinkers and a $65 \mathrm{~cm}$ long open trough feeder provided with an adjustable front door. Broilers were fed AL from 1 to $6 \mathrm{~d}$ of age. The experimental design was completely randomized with 4 treatments that consisted in the physical restriction of the access of the birds to feed, by manual closure of the feeders, for $0,4,6$, or $8 \mathrm{~h}$ per day from $\mathrm{d} 7$ until the end of the experiment at $19 \mathrm{~d}$ of age. Each treatment was replicated 6 times and the experimental unit was the cage for all measurements. All birds were kept under a 24-h continuous light program with $\mathrm{AL}$ access to water throughout the experiment. Room temperature was maintained at $32^{\circ} \mathrm{C}$ during the first $3 \mathrm{~d}$ of life and then, it was reduced gradually until reaching $23^{\circ} \mathrm{C}$ at $19 \mathrm{~d}$ of age. All birds received a common commercial diet based on cereals and soybean meal, with 3,000 kcal apparent metabolizable energy corrected for nitrogen (AMEn)/kg and 1.28\% standardized digestible Lys (22.0\% crude protein). The ingredient composition and the calculated (FEDNA, 2019) and determined nutrient content of the crumble diet used during the whole experiment are shown in Table 3. 
Table 3. Ingredient composition and chemical analysis of the experimental diet (\%).

Experiments 1 and 2.

Ingredient

Wheat

37.2

Corn

20.0

Soybean meal, $47 \%$ crude protein

31.3

Barley

Calcium carbonate

Dicalcium phosphate

Soy oil

L-Lys, 50\%

0.40

DL-Met, 99\%

0.36

L-Thr, 99\%

0.16

Sodium chloride

0.28

Sodium bicarbonate

0.10

Vitamin-mineral premix ${ }^{1}$

0.40

Calculated analysis

AMEn, $\mathrm{kcal} / \mathrm{kg}$

3,000

Ether extract

Neutral detergent fiber

9.5

Calcium

0.98

Phosphorus

0.54

Digestible phosphorus

0.40

Sodium

0.16

Chloride

Digestible amino acids

Lys

Met

Met+Cys

0.95

Thr

0.82

Trp

0.23

Ile

0.79

Detemined analysis

Moisture

Gross energy, kcal/kg

Crude protein

Neutral detergent fiber

Total ash

\footnotetext{
Abbreviation: AMEn, apparent metabolizable energy corrected for nitrogen

${ }^{1}$ Included per kilogram of feed: vitamin A, 8,000 IU; vitamin $\mathrm{D}_{3}$, 4,000 IU; vitamin E, $15 \mathrm{IU}$; vitamin $\mathrm{K}_{3}, 2 \mathrm{mg}$; vitamin $\mathrm{B}_{2}, 5.5 \mathrm{mg}$; vitamin $\mathrm{B}_{6}, 2 \mathrm{mg}$; vitamin $\mathrm{B}_{12}, 13 \mathrm{mcg}$; niacin, $25 \mathrm{mg}$; Capantothenate, $9 \mathrm{mg}$; pantothenic acid, $8 \mathrm{mg}$; folic acid, $0.5 \mathrm{mg}$; biotin, $100 \mathrm{mcg}$; choline chloride, $100 \mathrm{mg}$; betaine, $150 \mathrm{mg}$; Zn, $52 \mathrm{mg}$; Cu, $6.2 \mathrm{mg}$; K, $1.2 \mathrm{mg}$; Se, $0.3 \mathrm{mg}$; Fe, $20 \mathrm{mg}$; butylated hydroxyanisole, $0.4 \mathrm{mg}$; butylated hydroxytoluene, $2 \mathrm{mg}$; 6-phytase (EC 3.1.3.26; DSM Nutritional Products Ltd., Madrid), 1,000 FYT; endo-1,4-beta-xylanase (EC 3.2.1.8; Adisseo France S.A.S., Montluçon, France), 1,220 U; endo-1,3 (4) beta-glucanase (EC 3.2.1.6; Adisseo France S.A.S., Montluçon, France), 152 U
} 


\subsubsection{Laboratory analysis}

A representative sample of the experimental diet was ground using a laboratory mill (Retsch Model Z-I, Stuttgart, Germany) fitted with a $0.75 \mathrm{~mm}$ screen and analyzed for moisture by oven-drying (method 930.15), ash by a muffle furnace (method 942.05), and nitrogen by combustion (method 968.06) using a Leco equipment (FP-528, Leco Corporation, St. Joseph, MI) as indicated by AOAC International (2005). Gross energy of the feed was determined using an adiabatic bomb calorimeter (model 6400, Parr Instrument Company, Moline, IL). The neutral detergent fiber of the diet was determined as indicated by Van Soest et al. (1991). All the analysis were conducted by duplicate. The $\mathrm{pH}$ of the drinking water and the diet (6.8 and 6.5, respectively) was measured using a portable pH meter (Model 507, Crison Instruments S.A., Barcelona, Spain). The $\mathrm{pH}$ of the diet was corresponded to the $\mathrm{pH}$ value obtained after $2 \mathrm{~h}$ of swirling by diluting $10 \mathrm{~g}$ of feed (ground with a $0.75 \mathrm{~mm}$ screen) in $200 \mathrm{ml}$ of distilled water.

\subsubsection{Measurements}

Feed disappearance and BW of the birds were recorded by cage at 7, 13, and $19 \mathrm{~d}$ of age to determine BW gain, FI, and FCR by period ( 7 to $13 \mathrm{~d}$ and 14 to $19 \mathrm{~d}$ of age) and cumulatively ( 7 to $19 \mathrm{~d}$ of age). At $10,13,16$, and $19 \mathrm{~d}$ of age, immediately before the start of the FR period, two birds per cage were randomly selected and euthanized by asphyxiation in $\mathrm{CO}_{2}$ atmosphere and weighed individually. The crop and the gizzard were carefully clamped to avoid any digesta mixing, excised, and weighed. The $\mathrm{pH}$ of the content of the two organs was measured in duplicate in situ using a digital $\mathrm{pH}$ meter equipped with a fine-tip glass electrode (model 507, Crison Instruments S. A., Barcelona, Spain) as indicated by Jiménez-Moreno et al. (2009a). Then, the crop and the gizzard were emptied from any digesta content and weighed again. The weight and the fresh 
digesta content of the two organs, expressed in absolute (g) and relative ( $R \mathbf{H} ; \%$ BW) terms, were determined. In addition, the crop content was oven-dried and weighed and the moisture content was calculated (method 930.15) as indicated by AOAC International (2005). The anticipatory feeding behavior of the birds, as a response to the length of the FR period, was measured indirectly by weighing the digesta content of the crop immediately before the start of the fasting period. At $19 \mathrm{~d}$ of age, representative samples of the crop content were collected from each replicate, frozen, and stored at $-20^{\circ} \mathrm{C}$ for the quantification of Lactobacillus spp. colonies (Ahmed et al., 2014). Briefly, the samples (approximately $1 \mathrm{~g}$ ) were serially diluted (1:10 dilution) with $9 \mathrm{~mL}$ of a $0.9 \%$ sterile saline solution, thoroughly mixed, and then plated on a specific selective growth medium (DeMan, Rogosa, Sharpe agar medium). The Lactobacillus agar plates were incubated for $48 \mathrm{~h}$ at $37^{\circ} \mathrm{C}$ under anaerobic conditions. The results were expressed as $\log 10 \mathrm{cfu} / \mathrm{g}$ of sample. The average of the two individual birds chosen at random from each replicate was used for all measurements for further statistical analysis.

\subsubsection{Statistical analysis}

The linear $(\mathbf{L})$ and quadratic $(\mathbf{Q})$ effects of the length of the physical restriction of the access to feed $(0,4,6$, or $8 \mathrm{~h}$ per day) on growth performance, proximal GIT traits, and Lactobacillus spp. count were determined by the regression procedure as indicated by SAS Institute (2018). Same type of analysis was conducted to determine the effects of the age of the birds on the development of the organ traits. In addition, the effects of age and the interaction of age with FR length, on growth performance traits and on the development of the proximal part of the GIT, were tested by the repeated measures analysis as indicated by Littell et al. (1998). The experimental unit was the cage for all traits. 


\subsection{Experiment 2: essays 1, 2, and 3}

3.2.1. Bird husbandry, experimental design, and diet

3.2.1.1. Experiment 2. Essay 1: Growth Performance. In total, 288 straight-run Ross 308 broilers, weighing $44.1 \pm 0.82 \mathrm{~g}$ at the arrival to the experimental station, were randomly allotted in groups of 12 to 24 battery cages. The cages $(100 \times 45$ x $40 \mathrm{~cm}$; Alternative Design, Siloam Springs, AR) were equipped with an open trough feeder (65 $\mathrm{cm}$ long) provided with an adjustable front door and 2 low pressure nipple drinkers. All birds were kept under a 24-h continuous light program with water freely available at all times. Room temperature was maintained at $32^{\circ} \mathrm{C}$ during the first $3 \mathrm{~d}$ of life and then reduced gradually until reaching $24^{\circ} \mathrm{C}$ at $14 \mathrm{~d}$ of age. All birds received the same common commercial diet fed in crumbles based on cereals and soybean meal as indicated for experiment 1 (Table 3). All broilers were fed AL from 1 to $5 \mathrm{~d}$ of age. The experimental design was completely randomized with 4 treatments that consisted in physical restriction of the access to feed by manual closure of the feeders for $0,4,6$, or $8 \mathrm{~h}$ per day from $6 \mathrm{~d}$ of age until the end of the experiment at $14 \mathrm{~d}$ of age. Each treatment was replicated 6 times and the experimental unit was the cage with 12 birds for all measurements.

3.2.1.2. Experiment 2. Essay 2: Gastrointestinal Tract Traits. Bird strain, and management conditions during the rearing period were similar to those indicated for experiment 2 (essay 1). The same batch of feed was used. At the arrival to the experimental farm, the chicks $(n=504)$, weighing $44.4 \pm 0.73 \mathrm{~g}$, were distributed in groups of 12 to 42 battery cages and 6 replicates were assigned at random to each of the 7 treatments used. All birds received the experimental diet AL from 1 to $5 \mathrm{~d}$ of age. From 6 to $14 \mathrm{~d}$ of age, the experimental design was completely randomized and organized as a $1+3 \times 2$ arrangement consisting of a positive control group with broilers fed AL and 6 
extra groups organized as a $3 \times 2$ factorial with broilers fasted for 4,6 , or $8 \mathrm{~h}$ under trained (TR; restricted access to feed every day from 6 to $14 \mathrm{~d}$ of age) or non-trained (NTR; fed AL from 6 to $13 \mathrm{~d}$ of age and then fasted only on d 14 of the experiment) conditions (Figure 4).

3.2.1.3. Experiment 2. Essay 3: Digesta retention in crop and gizzard. Bird strain, initial BW, experimental diet, and all management conditions were similar to those indicated for experiment 2 (essay 2). All birds were fed AL from 0 to $5 \mathrm{~d}$ of age. From 6 to $14 \mathrm{~d}$ of age, the experimental design was similar to that indicated for experiment 2 (essay 2). Briefly, the experimental design was completely randomized with 7 treatments organized as a $1+3 \times 2$ arrangement with a positive control group with birds fed AL (0 $\mathrm{h}$ of FR) and 6 extra treatments organized as a $3 \times 2$ factorial with 3 lengths of the FR period $(4,6$, and $8 \mathrm{~h}$ ) applied to birds TR (fasted every day from 6 to $14 \mathrm{~d}$ of age) or NTR (fed AL from 6 to $13 \mathrm{~d}$ of age and then fasted on $\mathrm{d} 14$ of the experiment exclusively) to the FR conditions. 
Figure 4. Description of the experimental treatments according to the fasting strategy used from 6 to $14 \mathrm{~d}$ of age ${ }^{1}$. Experiment 2 . Essays 2 and 3.

\begin{tabular}{|c|c|c|c|c|c|c|}
\hline \multirow[t]{2}{*}{ FR strategy } & \multirow[t]{2}{*}{ Fasting period } & \multicolumn{5}{|c|}{ Age of the birds } \\
\hline & & 1 to 5 days & \multicolumn{2}{|c|}{6 to 13 days } & \multicolumn{2}{|c|}{14 days } \\
\hline Control birds & $0 \mathrm{~h}$ & $\mathrm{AL}(24 \mathrm{~h})$ & \multicolumn{2}{|c|}{ AL $(24 h)$} & \multicolumn{2}{|c|}{ AL $(24 \mathrm{~h})$} \\
\hline \multicolumn{7}{|l|}{ Trained birds } \\
\hline & $4 \mathrm{~h}$ & AL $(24 h)$ & $\mathrm{AL}(20 \mathrm{~h})$ & FR (4h) & $\mathrm{AL}(20 \mathrm{~h})$ & FR $(4 \mathrm{~h})$ \\
\hline & $6 \mathrm{~h}$ & AL $(24 h)$ & $\operatorname{AL}(18 h)$ & $\mathrm{FR}(6 \mathrm{~h})$ & AL (18 h) & $\mathrm{FR}(6 \mathrm{~h})$ \\
\hline & $8 \mathrm{~h}$ & AL $(24 h)$ & AL $(16 h)$ & FR $(8 \mathrm{~h})$ & $\operatorname{AL}(16 \mathrm{~h})$ & $\mathrm{FR}(8 \mathrm{~h})$ \\
\hline \multicolumn{3}{|c|}{ Non-trained birds } & \multicolumn{2}{|c|}{ AL $(24 h)$} & AL $(20 \mathrm{~h})$ & FR $(4 h)$ \\
\hline & $6 \mathrm{~h}$ & AL $(24 h)$ & \multicolumn{2}{|c|}{$\mathrm{AL}(24 \mathrm{~h})$} & AL (18 h) & $\mathrm{FR}(6 \mathrm{~h})$ \\
\hline & $8 \mathrm{~h}$ & AL $(24 h)$ & \multicolumn{2}{|c|}{ AL (24 h) } & $\mathrm{AL}(16 \mathrm{~h})$ & FR $(8 h)$ \\
\hline
\end{tabular}

Abbreviations: AL, ad libitum; FR, feed restriction

${ }^{1}$ The experimental design was organized as a $1+3 \times 2$ arrangement with a positive control group with broilers fed AL and 6 extra groups with broilers fasted for 4,6 , or $8 \mathrm{~h}$ under trained or non-trained conditions 


\subsubsection{Laboratory analysis}

A representative sample of the experimental diet was ground using a laboratory mill (Retsch Model Z-I, Stuttgart, Germany) fitted with a $0.75 \mathrm{~mm}$ screen and analyzed for moisture, ash, nitrogen, gross energy, and neutral detergent fiber as indicated in experiment 1 . In addition, the $\mathrm{pH}$ of the drinking water and diet (6.8 and 6.9, respectively) was measured using a portable $\mathrm{pH}$ meter (Model 507, Crison Instruments S.A., Barcelona, Spain).

\subsubsection{Measurements}

3.2.3.1. Experiment 2. Essay 1: Growth performance. Feed disappearance and BW of the birds were determined by cage at 6 and $14 \mathrm{~d}$ of age. Mortality was recorded as produced and the data was used to adjust FCR. From these data, BW gain, FI, and FCR were calculated.

3.2.3.2. Experiment 2. Essay 2: Gastrointestinal tract traits. At $15 \mathrm{~d}$ of age, all the birds except those of the control group, were fasted by physical restriction of the access to feed according to their corresponding experimental treatment. Immediately after the end of the fasting period, all birds had free access to feed for $60 \mathrm{~min}$ and then, two birds per cage, randomly selected, were slaughtered by asphyxiation in $\mathrm{CO}_{2}$ atmosphere, and immediately weighed. The crop and the gizzard were clamped to avoid any digesta mixing, excised, and weight. The $\mathrm{pH}$, weight, and content of the two organs was measured as indicated for experiment 1 . The empty weight and the fresh digesta content of the two organs, expressed in relative terms $(\% \mathrm{BW})$, were determined. In addition, the moisture content of the crop digesta was calculated. The average value of the two individual birds of each replicate, was used for further statistical analysis for all measurements. 
3.2.3.3. Experiment 2. Essay 3: Digesta retention in crop and gizzard. At $15 \mathrm{~d}$ of age, all the birds, except those of the positive control group, were fasted according to their corresponding treatment. Then, the birds had free access to feed for $60 \mathrm{~min}$ and then the feed was removed. For the next $4 \mathrm{~h}$, two birds per cage were randomly selected at onehour intervals, slaughtered by asphyxiation in $\mathrm{CO}_{2}$ atmosphere, weighed individually (BW of $485 \pm 42 \mathrm{~g}$ ), and used to evaluate the effect of the fasting strategy used on crop and gizzard development and content (Figure 5). The digesta content (\% BW) and $\mathrm{pH}$ of the crop and the gizzard were determined as indicated for experiment 2 (essay2). The experimental unit was the cage for all measurements and the average value of the 2 individual birds from each replicate was used for further statistical analysis. 
Figure 5. Time schedule used for the measurements performed at $14 \mathrm{~d}$ of age to evaluate the effects of feed restriction on the digesta retention in crop and gizzard according to the fasting strategy used. Experiment 2. Essay 3.

Fasting strategy Fasting period (h)

Timeline of physical access to feed

Trained birds ${ }^{1}$

8

Non-trained birds ${ }^{2}$

\begin{tabular}{c|c|c|}
$A L(20 h)$ & $F R(4 h)$ & $A L(1 h)$ \\
\hline$A L(18 h)$ & $F R(6 h)$ & $A L(1 h)$
\end{tabular}

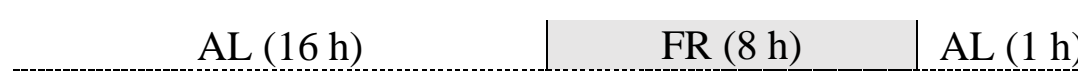

8

\begin{tabular}{c|c|c} 
AL $(20 h)$ & FR $(4 h)$ & AL $(1 h)$ \\
$A L(18 h)$ & FR $(6 h)$ & AL $(1 h)$ \\
\hline$A L(16 h)$ & FR $(8 h)$ & AL $(1 h)$
\end{tabular}

Abbreviations: AL, ad libitum; FR, feed restriction

${ }^{1}$ Restricted access to feed daily from 6 to $14 \mathrm{~d}$ of age

${ }^{2}$ Restricted access to feed exclusively on $\mathrm{d} 14$

${ }^{3}$ Two birds per cage were randomly selected every hour after feed removal to determine crop ang gizzard development and content 


\subsubsection{Statistical analysis}

3.2.4.1. Experiment 2. Essay 1: Growth performance. Data were analyzed as a completely randomized design with 4 treatments that consisted in the physical restriction of the access to feed for $0,4,6$, or $8 \mathrm{~h}$ per day from 6 to $14 \mathrm{~d}$ of age. The MIXED procedure of SAS (SAS Institute, 2018) was used and when significant differences were detected $(P$ $<0.05)$, mean values were separated using the Tukey test. In addition, the $\mathrm{L}$ and $\mathrm{Q}$ effects of the length of the FR period on growth performance traits were determined by the regression procedure of SAS (SAS Institute, 2018). The experimental unit was the cage for all traits.

3.2.4.2. Experiment 2. Essay 2: Gastrointestinal tract traits. The effects of previous training of the birds to fasting (TR vs. NTR) on the development of the GIT were analyzed as a completely randomized design using the MIXED procedure of SAS (SAS Institute, 2018). In addition, a covariance analysis (ANCOVA) was used to evaluate the L and Q effects of the length of the FR period on GIT traits. In the analysis, the determined slopes of the two set of data (TR and NTR birds) were compared by including in the model the data from the control group (broilers fed AL throughout the experiment). The experimental unit was the cage (average of 2 birds per replicate) for all traits and when significant differences were detected $(P<0.05)$ mean values were separated using the Tukey test.

3.2.4.3. Experiment 2. Essay 3. Digesta retention in crop and gizzard. The effects of previous training of the birds to fasting (TR vs. NTR) on GIT traits were analyzed as a completely randomized design using the MIXED procedure of SAS (SAS Institute, 2018). In addition, a covariance analysis (ANCOVA) was used to evaluate the effects of 
the length of the FR period on GIT traits, including in the model the data from the control group with broilers fed AL $(0 \mathrm{~h})$ throughout the experiment. The effects of the time elapsed after feed removal ( 0 to $4 \mathrm{~h}$ ) on organ traits and the interactions with training and the length of the fasting period were analyzed by the repeated measures analysis. The experimental unit was the cage (average of 2 birds per replicate) for all traits.

\subsection{Experiment 3}

\subsubsection{Bird husbandry, experimental design, and diet}

In total, 360 straight-run chicks (240 Cobb 500 and 120 Hubbard JA757) were obtained from a commercial hatchery, were used. The chicks were obtained from a breeder flock at 43 wk of age and 54 wk of age, for the Cobb and Hubbard strains, respectively. Based on the HW, the Cobb birds were classified as Cobb-24 (HW of $24 \mathrm{~h}$ ) or Cobb-48 (HW of 48 h). The Hubbard JA757 birds were hatched the same day than the Cobb birds and had a 24-h HW (Hubbard-24). For the Cobb birds, two adjacent trays within the same setter were selected. At $24 \mathrm{~h}$ after the first egg hatched, all chicks in tray one were discarded whereas chicks in tray two remained unaltered. After a $24-\mathrm{h}$ extra period, the chicks were removed and 120 birds were selected at random from each tray (Cobb-24 and Cobb-48, respectively). For the Hubbard-24 birds, the same procedure indicated for the Cobb-24 birds was followed. As a result, the HW of the chicks was 24 $\mathrm{h}(\mathrm{Cobb}-24)$ for the first tray and $48 \mathrm{~h}(\mathrm{Cobb}-48)$ for the second tray. Then, all the birds were simultaneously processed at the hatchery $(3 \mathrm{~h})$ and transported to the experimental farm $(6 \mathrm{~h})$. As a result, the time span between the hatching of the first egg to the arrival to the experimental farm was of $<33 \mathrm{~h}$ for the Cobb-24 and the Hubbard-24 and $<57 \mathrm{~h}$ for the Cobb-48 birds, a period in which the chicks had no access to feed or water. At the arrival to the experimental farm, the chicks with a BW of $40.7 \pm 0.87,35.1 \pm 1.33$, and 
$39.3 \pm 1.13 \mathrm{~g}$ for the Cobb-24, Cobb-48, and Hubbard-24, were distributed at random, according to type, into 24 battery cages in groups of 10 . The cages $(100 \times 45 \times 40 \mathrm{~cm}$; Alternative Design, Siloam Springs, AR) were equipped with an open trough feeder (65 $\mathrm{cm}$ long) provided with an adjustable front door and 2 low pressure nipple drinkers. Room temperature was maintained at $32^{\circ} \mathrm{C}$ during the first $3 \mathrm{~d}$ and then it was reduced gradually until reaching $22^{\circ} \mathrm{C}$ at $21 \mathrm{~d}$ of age. Chicks had $23 \mathrm{~h}$ of light per day for the first week of life, with water and feed available at all times. From 7 to $21 \mathrm{~d}$ of age, all birds were kept under a 20-h light program. Within each type of broilers, half of the replicates were fed AL whereas the other half had an additional physical restriction with no access to feed immediately after the start of the lighting period. As a result, the FR period applied was of $4 \mathrm{~h}$ (period of darkness) or $8 \mathrm{~h}$ ( $4 \mathrm{~h}$ of darkness plus 4 extra hours of physical restriction), respectively. Throughout the experiment, all broilers were fed a common mash diet low in nutrients (FEDNA, 2018) intended to maximize feed consumption under fasting conditions while compromising the capacity of the birds to meet their nutritional requirements. Water was freely available at all times. The ingredient composition and the calculated and determined nutrient content of the experimental diet are shown in Table 4 (FEDNA, 2019). The experimental design was completely randomized with 6 treatments arranged as a $3 \times 2$ factorial with 3 types of broilers (Cobb-24, Cobb-48, and Hubbard24) and 2 lengths of the FR period applied ( 4 vs. $8 \mathrm{~h} / \mathrm{d}$ ) from 7 to $21 \mathrm{~d}$ of age. 
Table 4. Ingredient composition and chemical analysis of the experimental diet (\%).

Experiment 3.

Ingredient

Wheat

36.5

Soybean meal, $45.5 \%$ crude protein

Corn

19.6

Barley

Rice bran

Calcium carbonate

Dicalcium phosphate

Peas

Soy oil

0.51

Sodium chloride

0.33

DL-Met, 99\%

0.21

Sodium bicarbonate

0.12

L-Lys, 50\%

0.22

Vitamin-mineral premix ${ }^{1}$

0.40

Calculated analysis

AMEn, $\mathrm{kcal} / \mathrm{kg}$

Ether extract

Crude fiber

Neutral detergent fiber

10.8

Calcium

0.99

Phosphorus

0.59

Digestible phosphorus

0.38

Sodium

0.18

Chloride

Digestible amino acid

$\begin{array}{ll}\text { Lys } & 0.99 \\ \text { Met } & 0.42 \\ \text { Met+Cys } & 0.75 \\ \text { Thr } & 0.64 \\ \text { Trp } & 0.21 \\ \text { Ile } & 0.72\end{array}$

Detemined analysis

Moisture

Gross energy, kcal/kg

Crude protein

Neutral detergent fiber

Total ash

Abbreviation: AMEn, apparent metabolizable energy corrected for nitrogen

${ }^{1}$ Included per kilogram of feed: vitamin A, 8,000 IU; vitamin $\mathrm{D}_{3}$, 4,000 IU; vitamin E, $15 \mathrm{IU}$; vitamin $\mathrm{K}_{3}, 2 \mathrm{mg}$; vitamin B2, $5.5 \mathrm{mg}$; vitamin B6, $2 \mathrm{mg}$; vitamin B12, 13 mcg; $Z \mathrm{n}, 52 \mathrm{mg}$; Cu, $6.2 \mathrm{mg}$; K, $1.2 \mathrm{mg}$; Se, $0.3 \mathrm{mg}$; Fe, $20 \mathrm{mg}$; niacin, $25 \mathrm{mg}$; Ca-pantothenate, $9 \mathrm{mg}$; pantothenic acid, $8 \mathrm{mg}$; folic acid, $0.5 \mathrm{mg}$; biotin, $100 \mathrm{mcg}$; choline chloride, $100 \mathrm{mg}$; betaine, $150 \mathrm{mg}$; butylated hydroxyanisole, $0.4 \mathrm{mg}$; butylated hydroxytoluene, $2 \mathrm{mg}$; 6-phytase (EC 3.1.3.26; DSM Nutritional Products Ltd., Madrid), 1,000 FYT; endo-1,4-beta-xylanase (EC 3.2.1.8; Adisseo France S.A.S., Montluçon, France), 1,220 U; endo-1,3 (4) beta-glucanase (EC 3.2.1.6; Adisseo France S.A.S., Montluçon, France), 152 U. 


\subsubsection{Laboratory analysis}

The particle size distribution and the geometric mean diameter $(686 \pm 2.22 \mu \mathrm{m})$ of a representative sample $(100 \mathrm{~g})$ of the mash diet were determined in triplicate as recommended by the ASAE (2003). A representative sample of the diet was ground using a laboratory mill (Retsch Model Z-I, Stuttgart, Germany) fitted with a $0.75 \mathrm{~mm}$ screen and analyzed for moisture ash. Nitrogen, gross energy, and neutral detergent fiber as indicated for experiment 1. The $\mathrm{pH}$ of the drinking water and diet (6.6 and 7.1, respectively) was measured using a portable $\mathrm{pH}$ meter as indicated for experiment 1.

\subsubsection{Measurements}

Feed consumption and BW of the birds were recorded by cage at 7 and $21 \mathrm{~d}$ of age. Mortality was recorded as produced and the data was used to adjust FCR. From these data, BW gain, FI, and FCR were calculated. At $21 \mathrm{~d}$ of age, immediately after the end of the FR period, all chicks had free access to feed for $60 \mathrm{~min}$. Then, two birds per cage were selected at random, slaughtered by asphyxiation in $\mathrm{CO}_{2}$ atmosphere, and weighed individually. The crop and the gizzard $\mathrm{pH}$, weight, and contents were measured in these birds as indicated for experiment 1 . The weight and contents of the two organs, expressed in absolute (g) and relative (\% BW) terms, were determined. The moisture content of the crop was also calculated as indicated for experiment 1 . The absolute and the RW of the full small intestine (SI; duodenum + jejunum + ileum) was also recorded in these birds. In addition, a representative sample of the crop content of two extra birds per cage were collected, frozen, and stored at $-20^{\circ} \mathrm{C}$. The number of colonies of Lactobacillus spp. in this organ were quantified as indicated for experiment 1 and the lactic acid concentration, expressed as $\mu \mathrm{mol} / \mathrm{g}$ of crop content, was measured by high-performance liquid chromatography (HPLC). Briefly, $1 \mathrm{~g}$ of sample was added to $9 \mathrm{~mL}$ sterile water, mixed 
in an ultrasonic bath during $10 \mathrm{~min}$, filtered, and injected $(20 \mu \mathrm{L})$ in a HPLC $150 \times 4.6$ mm column (ACE C18-PFP, Advanced Chromatography Technologies Ltd., Aberdeen, UK) with a $50 \mathrm{mM}$ H3PO4 flow solution $(0.8 \mathrm{~mL} / \mathrm{min})$. The ultraviolet detector wavelength was $214 \mathrm{~nm}$ and the column temperature was $33^{\circ} \mathrm{C}$. The average of the two birds per replicate was used for all measurements as the experimental unit for further statistical analysis.

\subsubsection{Statistical analysis}

Data on growth performance ( 7 to $21 \mathrm{~d}$ of age) and organ traits ( $21 \mathrm{~d}$ of age) were analyzed using the MIXED procedure of SAS (SAS Institute, 2018), with type of broiler and length of the FR period as main effects. Each treatment was replicated 6 times and the experimental unit was the cage with 10 birds for all variables. When significant differences among treatments were detected $(P<0.05)$, mean values were separated using the Tukey test. 
RESULTS 


\section{RESULTS}

\subsection{Experiment 1}

\subsubsection{Growth performance}

No mortality occurred during the experiment. From 7 to $19 \mathrm{~d}$ of age, an increase in the length of the fasting period from 0 to $8 \mathrm{~h}$ per day decreased FI $(\mathrm{L}, P<0.01 ; \mathrm{Q}, P<$ $0.05)$ and $\mathrm{BW}$ gain $(\mathrm{L}, P<0.01 ; \mathrm{Q}, P=0.079)$, with effects that were more evident when the FR period lasted for $6 \mathrm{~h}$ or more (Table 5). Also, the effects of FR on FI and BW gain were more evident from 7 to $13 \mathrm{~d}$ of age (L, $P<0.01$; Q, $P<0.05$ ) than from 14 to $19 \mathrm{~d}$ of age (L; $P=0.056$ and $P=0.065$ for FI and BW gain, respectively). Feed restriction, however, did not affect FCR in any of the periods considered.

Table 5. Effects of the length of the fasting period on growth performance of broilers from 7 to $19 \mathrm{~d}$ of age ${ }^{1}$. Experiment 1 .

\begin{tabular}{|c|c|c|c|c|c|c|c|c|}
\hline & \multicolumn{4}{|c|}{ Fasting period $(\mathrm{h} / \mathrm{d})$} & \multirow{2}{*}{$\begin{array}{l}\text { SEM } \\
(n=6)\end{array}$} & \multirow{2}{*}{$\begin{array}{c}\text { P- } \\
\text { value }^{2,3}\end{array}$} & \multicolumn{2}{|c|}{ Regression } \\
\hline & 0 & 4 & 6 & 8 & & & Linear & Quadratic \\
\hline \multicolumn{9}{|l|}{7 to 13 days } \\
\hline $\mathrm{FI}(\mathrm{g} / \mathrm{d})$ & $46.1^{\mathrm{a}}$ & $47.4^{\mathrm{a}}$ & $43.6^{\mathrm{b}}$ & $42.5^{\mathrm{b}}$ & 0.71 & $<0.001$ & $<0.010$ & $<0.050$ \\
\hline BW gain $(g / d)$ & $36.8^{\mathrm{a}}$ & $37.8^{\mathrm{a}}$ & $34.5^{\mathrm{b}}$ & $33.7^{\mathrm{b}}$ & 0.50 & $<0.001$ & $<0.001$ & $<0.050$ \\
\hline FCR $(\mathrm{g} / \mathrm{g})$ & 1.25 & 1.26 & 1.26 & 1.26 & 0.008 & 0.625 & 0.260 & 0.917 \\
\hline \multicolumn{9}{|l|}{14 to 19 days } \\
\hline $\mathrm{FI}(\mathrm{g} / \mathrm{d})$ & 72.7 & 71.6 & 71.3 & 66.5 & 1.96 & 0.147 & 0.056 & 0.237 \\
\hline BW gain $(g / d)$ & 55.6 & 54.0 & 54.1 & 50.8 & 1.59 & 0.229 & 0.065 & 0.446 \\
\hline FCR $(\mathrm{g} / \mathrm{g})$ & 1.31 & 1.33 & 1.32 & 1.31 & 0.019 & 0.837 & 0.994 & 0.365 \\
\hline \multicolumn{9}{|l|}{7 to 19 days } \\
\hline FI $(g / d)$ & $56.3^{\mathrm{a}}$ & $56.7^{\mathrm{a}}$ & $54.2^{\mathrm{ab}}$ & $51.7^{\mathrm{b}}$ & 1.04 & $<0.010$ & $<0.010$ & $<0.050$ \\
\hline BW gain $(\mathrm{g} / \mathrm{d})$ & $44.0^{\mathrm{a}}$ & $44.0^{\mathrm{a}}$ & $42.0^{\mathrm{ab}}$ & $40.3^{\mathrm{b}}$ & 0.81 & $<0.050$ & $<0.010$ & 0.079 \\
\hline $\mathrm{FCR}(\mathrm{g} / \mathrm{g})$ & 1.28 & 1.29 & 1.29 & 1.28 & 0.011 & 0.867 & 0.686 & 0.489 \\
\hline
\end{tabular}

Abbreviations: FI, feed intake; BW, body weight, FCR, feed conversion ratio

${ }^{1}$ The $\mathrm{BW}$ at $7 \mathrm{~d}$ of age was $131.7 \pm 5.3,131.0 \pm 3.0,131.8 \pm 5.1$, and $131.2 \pm 2.4 \mathrm{~g}$ for broilers fasted for $0,4,6$, and $8 \mathrm{~h} / \mathrm{d}$ from 7 to $19 \mathrm{~d}$ of age, respectively, and was similar $(\mathrm{P}>0.100)$ among treatments ${ }^{2} \mathrm{P}$-values from the analysis of variance

${ }^{3}$ Age of the birds affected all the variables studied $(\mathrm{P}<0.001)$. No interactions between FR length and age of the birds were detected for any of the variables studied 


\subsubsection{Gastrointestinal tract traits}

No interactions between age of the birds and the length of the fasting period were detected for any of the GIT traits studied and consequently, only main effects are presented.

4.1.2.1. Age of the bird. From 10 to $19 \mathrm{~d}$ of age, the absolute weight of the empty crop increased (L; $P<0.001)$ with bird age (Figure 6a). In relative terms, however, an opposite effect was observed and the RW of the empty crop decreased $(\mathrm{L} ; P<0.001)$ with age (Figure 6b). The absolute weight of the fresh content of the crop digesta (L, Q; $P<$ $0.05)$ and its moisture content $(\%)(\mathrm{L} ; P<0.001)$ increased with age (Figure 7$)$. As a result, the dried content $(\mathrm{g})$ of the crop digesta was not affected by bird age. In relative terms, however, the weight of the fresh content of the digesta of the crop decreased (L; $P$ $<0.01)$ with age.

The weight of the empty gizzard and its fresh content increased $(\mathrm{L} ; P<0.01)$ with age in absolute terms (Figure 8a) but decreased (L; $P<0.001$ ) in relative terms (Figure $8 \mathrm{~b})$. The $\mathrm{pH}$ of the crop decreased with age (L, $P<0.001 ; \mathrm{Q} ; P<0.05)$ with the highest value observed at $13 \mathrm{~d}$ of age (Figure 9). Gizzard $\mathrm{pH}$, however, was not affected by bird age. 
Figure 6. Influence of age (means \pm SEM) on the weight of the empty crop and its content in absolute (a) and relative (b) terms. Mean values per age correspond to 48 observations (average of 4 treatments, corresponding to fasting periods of $0,4,6$, and $8 \mathrm{~h} / \mathrm{d}$, and 12 chicks per treatment and age). P-values in brackets correspond to data from the regression analysis ( $\mathrm{L}=$ Lineal; $\mathrm{Q}=$ Quadratic). Experiment $1^{1}$.

a)

-•- Empty crop, g; L $(P<0.001)$

.... Crop content, g; L $(P<0.05), \mathrm{Q}(P<0.05)$

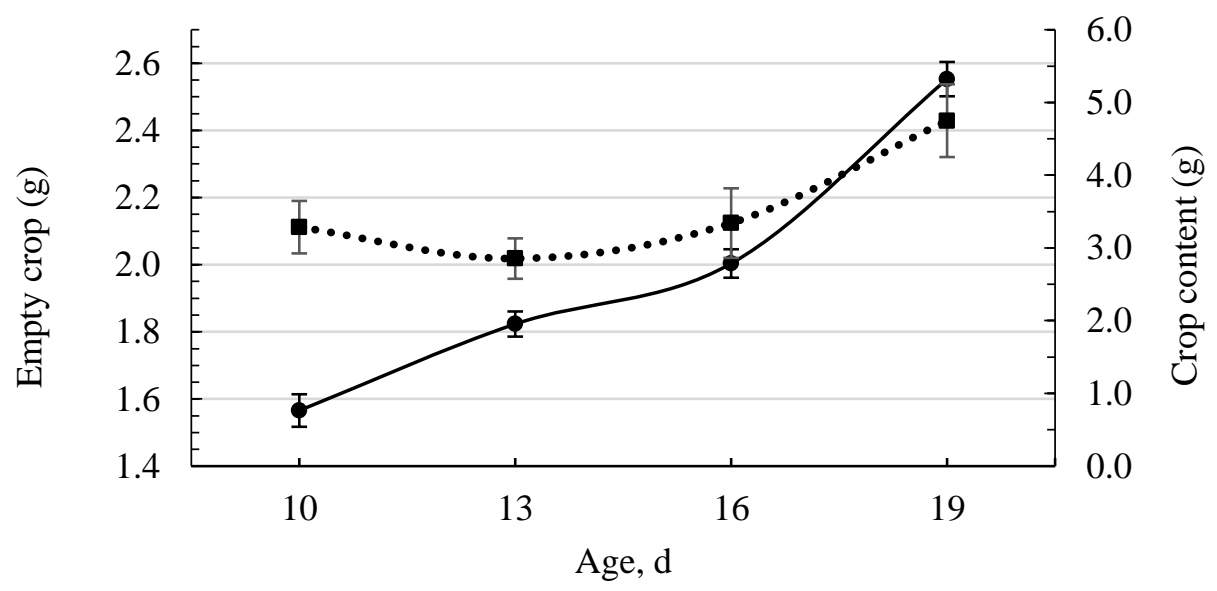

b)

-•- Empty crop, \% BW; L $(P<0.001)$

-"-.' Crop content, \% BW; L $(P<0.01)$

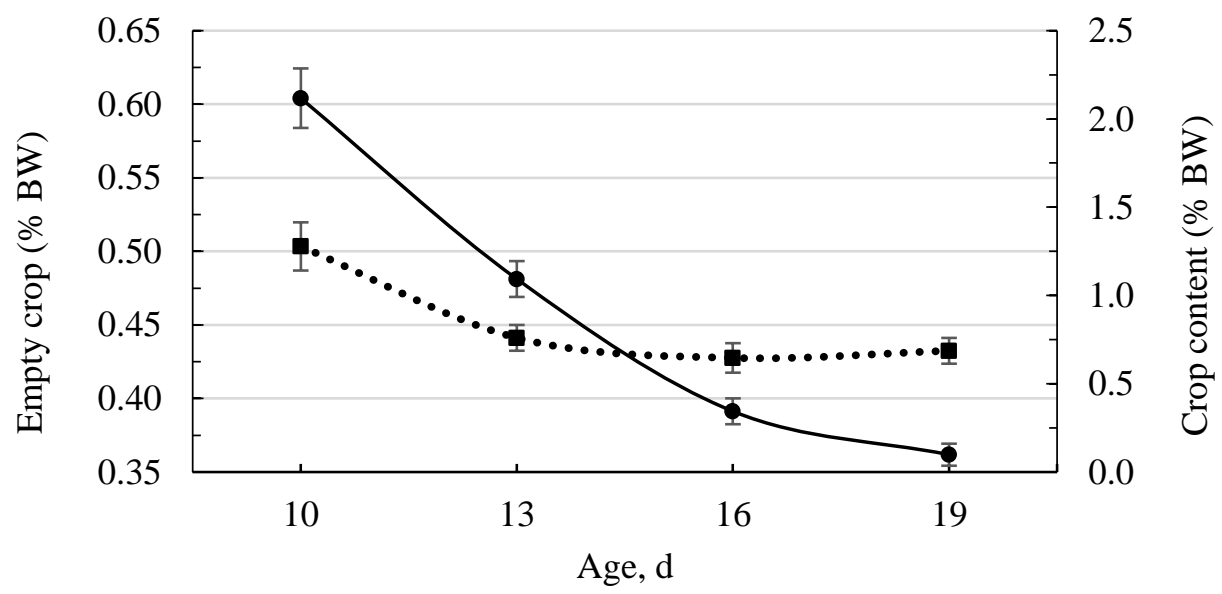

${ }^{1}$ No interactions between FR length and age of the birds were detected for any of the traits studied 
Figure 7. Influence of age (means \pm SEM) on the moisture (\%) and dried (g) content of the crop. Mean values per age correspond to 48 observations (average of 4 treatments, corresponding to fasting periods of $0,4,6$, and $8 \mathrm{~h} / \mathrm{d}$, and 12 chicks per treatment and age). P-values in brackets correspond to data from the regression analysis ( $\mathrm{L}=$ Lineal; NS $=$ Not significant). Experiment $1^{1}$.

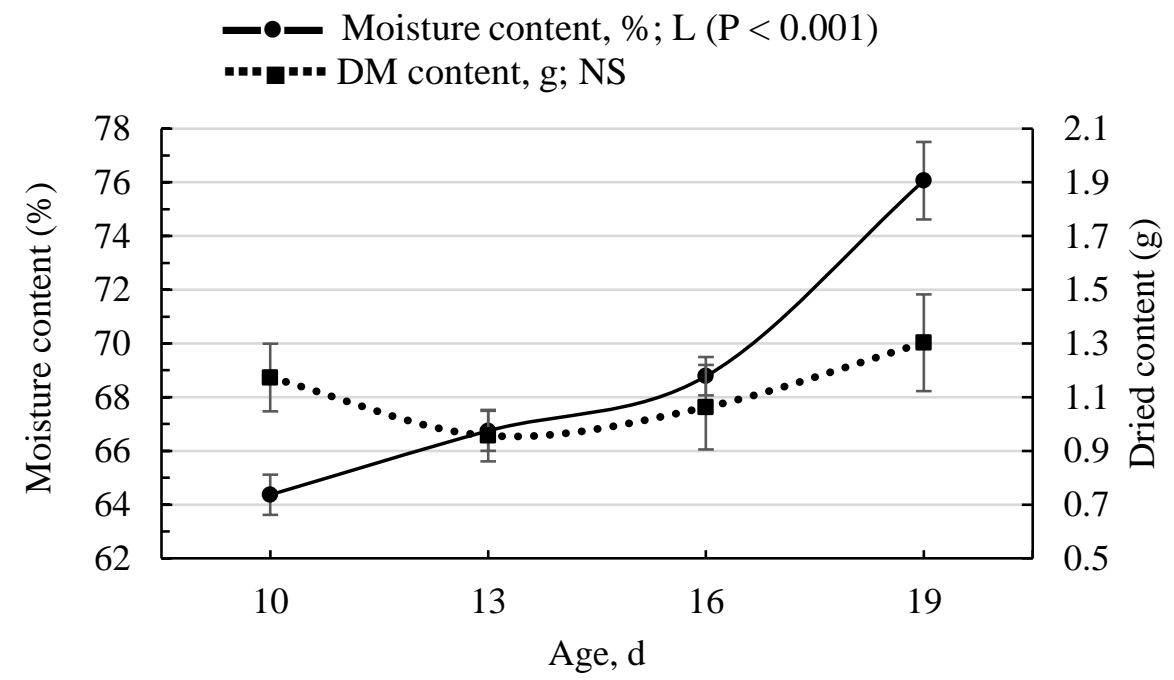

${ }^{1}$ No interactions between FR length and age of the birds were detected for any of the traits studied 
Figure 8. Influence of age (means \pm SEM) on the weight of the empty gizzard and its content in absolute (a) and relative (b) terms. Mean values per age correspond to 48 observations (average of 4 treatments, corresponding to fasting periods of $0,4,6$, and 8 $\mathrm{h} / \mathrm{d}$, and 12 chicks per treatment and age). P-values in brackets correspond to data from the regression analysis $(\mathrm{L}=\mathrm{Lineal} ; \mathrm{Q}=\mathrm{Quadratic})$. Experiment $1^{1}$.

a)

-•- Empty gizzard, g; L $(P<0.01)$

-."-. Gizzard content, g; L $(P<0.01)$

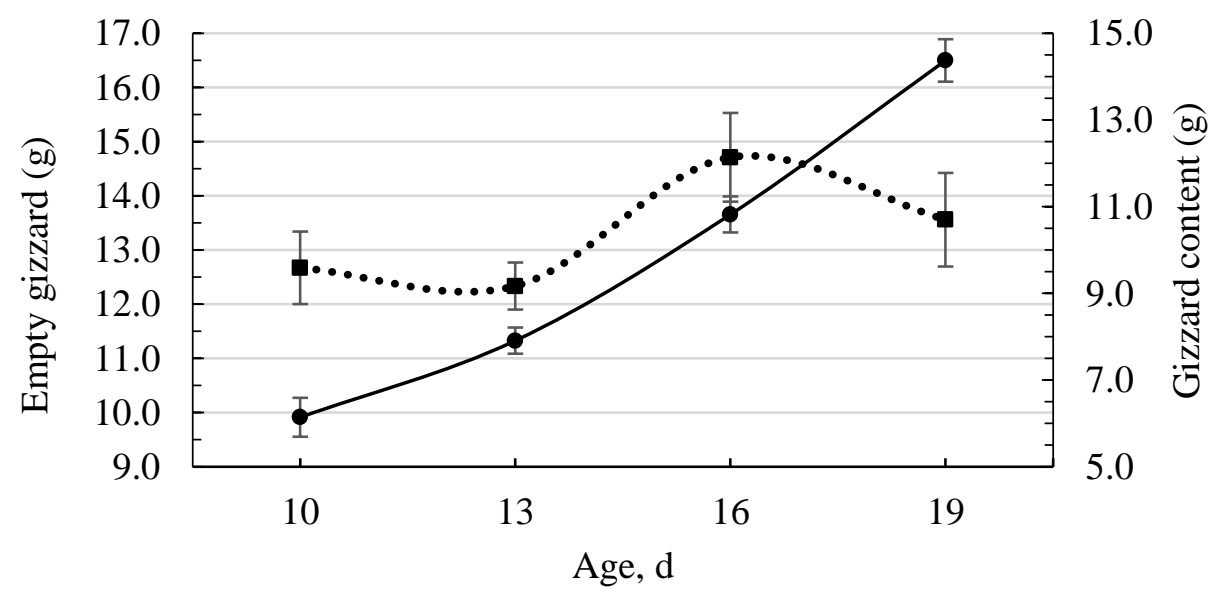

b)

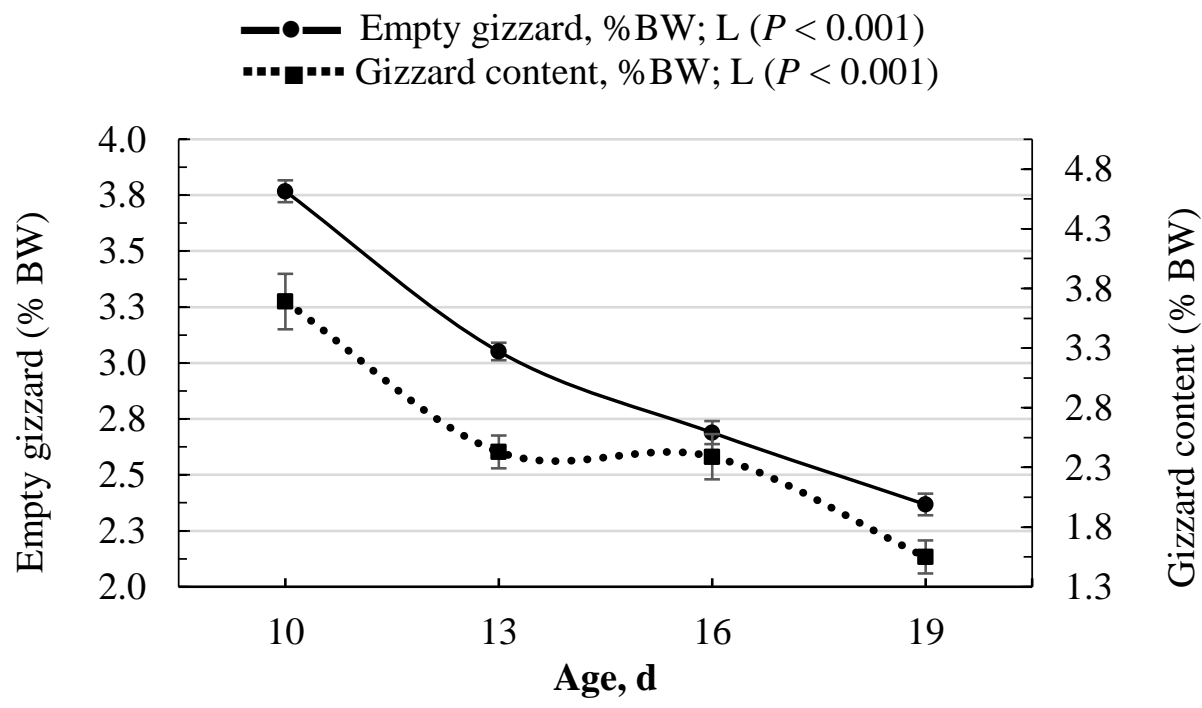

${ }^{1}$ No interactions between FR length and age of the birds were detected for any of the traits studied 
Figure 9. Influence of age (means $\pm \mathrm{SEM}$ ) on crop and gizzard $\mathrm{pH}$. Mean values per age correspond to 48 observations (average of 4 treatments, corresponding to fasting periods of $0,4,6$, and $8 \mathrm{~h} / \mathrm{d}$, and 12 chicks per treatment and age). P-values in brackets correspond to data from the regression analysis ( $\mathrm{L}=$ Lineal; $\mathrm{Q}=$ Quadratic; NS = Not significant). Experiment $1^{1}$.

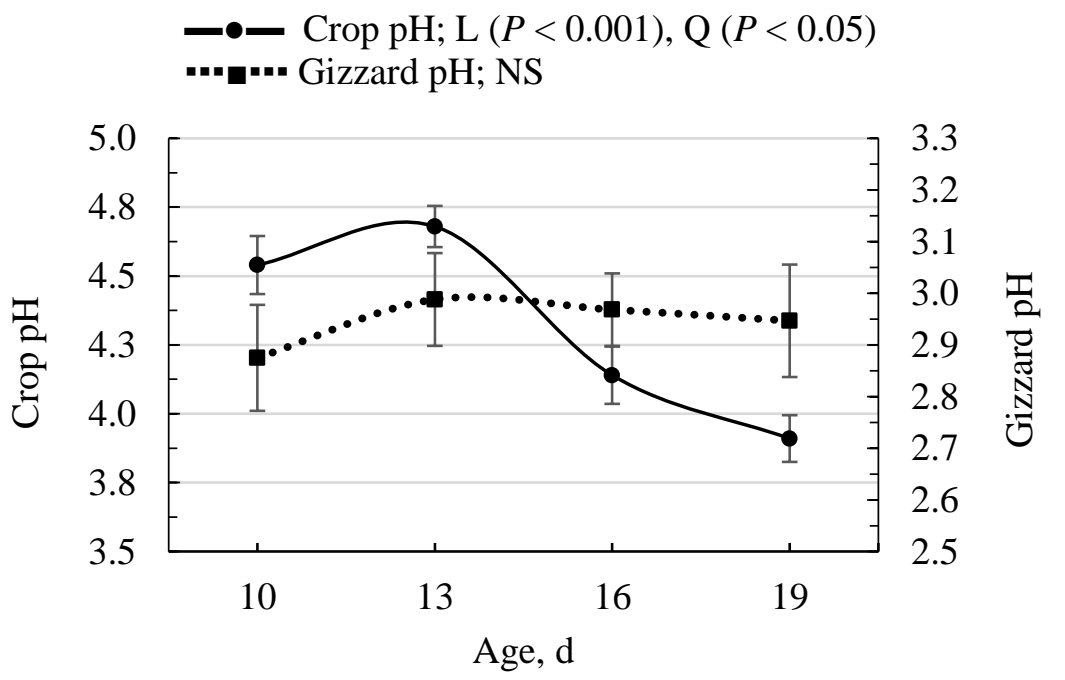

${ }^{1}$ No interactions between FR length and age of the birds were detected for any of the traits studied

4.1.2.2. Feed restriction. An increase in length of the FR period increased (L; $P<$ 0.001) the weight of the empty crop in absolute and relative terms at all ages (Table 6). The weight of the fresh content of the crop, in absolute and relative terms, increased as the length of the FR period increased (L, Q; $P<0.001)$ with effects that were more evident with fasting periods of $6 \mathrm{~h}$ or more. The moisture content of the crop digesta (\%) decreased $(\mathrm{L} ; P<0.001)$ as the length of the fasting period increased (Table 7). As a result, the dried content $(\mathrm{g})$ of the crop digesta increased as the length of the fasting period increased (L, Q; $P<0.001)$, with effects that were more evident when the fasting period lasted for $6 \mathrm{~h}$ or more. In general, fasting did not affect the weight of the gizzard at any age (Table 8). 
Table 6. Effects of the length of the fasting period on selected crop traits. Experiment 1.

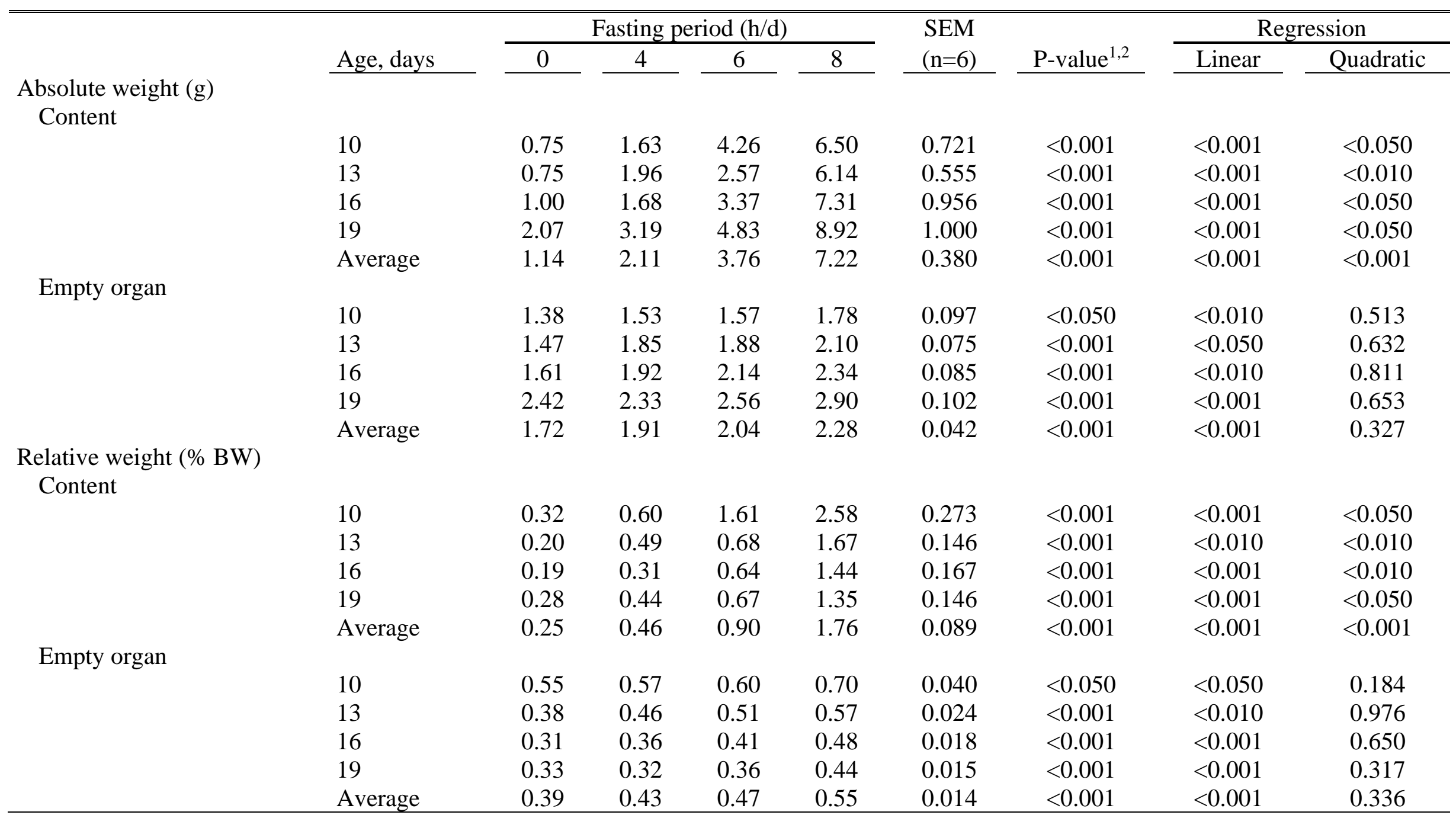

Abbreviation: BW, body weight

${ }^{1} \mathrm{P}$-values from the analysis of variance

${ }^{2}$ No interactions between FR length and age of the birds were detected for any of the traits studied 
Table 7. Effects of the length of the fasting period on selected crop traits. Experiment 1.

\begin{tabular}{|c|c|c|c|c|c|c|c|c|c|}
\hline \multirow[b]{3}{*}{ Dried content (g) } & \multirow[b]{2}{*}{ Age, days } & \multicolumn{4}{|c|}{ Fasting period $(\mathrm{h} / \mathrm{d})$} & \multirow{2}{*}{$\begin{array}{l}\text { SEM } \\
(\mathrm{n}=6)\end{array}$} & \multirow[b]{2}{*}{ P-value ${ }^{1,2}$} & \multicolumn{2}{|c|}{ Regression } \\
\hline & & 0 & 4 & 6 & 8 & & & Linear & Quadratic \\
\hline & 10 & 0.24 & 0.52 & 151 & 243 & 0.252 & $<0,001$ & $<0.001$ & $<0.050$ \\
\hline & 13 & 0.14 & 0.55 & 0.87 & 2.26 & 0.192 & $<0.001$ & $<0.001$ & $<0.010$ \\
\hline & 16 & 0.27 & 0.49 & 1.00 & 2.50 & 0.315 & $<0.001$ & $<0.001$ & $<0.050$ \\
\hline & 19 & 0.31 & 0.43 & 1.24 & 3.23 & 0.360 & $<0.001$ & $<0.001$ & $<0.010$ \\
\hline & Average & 0.24 & 0.50 & 1.15 & 2.60 & 0.122 & $<0.001$ & $<0.001$ & $<0.001$ \\
\hline \multicolumn{10}{|c|}{ Moisture content (\%) } \\
\hline & 10 & 67.7 & 66.6 & 64.1 & 62.4 & 1.50 & 0.146 & $<0.050$ & 0.856 \\
\hline & 13 & 83.0 & 71.8 & 65.3 & 63.1 & 1.49 & $<0.001$ & $<0.001$ & 0.206 \\
\hline & 16 & 73.2 & 70.7 & 69.8 & 65.8 & 1.43 & $<0.050$ & $<0.050$ & 0.415 \\
\hline & 19 & 86.1 & 86.7 & 77.7 & 63.8 & 2.89 & $<0.001$ & $<0.001$ & 0.498 \\
\hline & Average & 77.2 & 74.0 & 69.3 & 63.8 & 0.77 & $<0.001$ & $<0.001$ & 0.764 \\
\hline
\end{tabular}

${ }^{1} \mathrm{P}$-values from the analysis of variance

${ }^{2}$ No interactions between FR length and age of the birds were detected for any of the traits studied 
Table 8. Effects of the length of the fasting period on selected gizzard traits. Experiment 1.

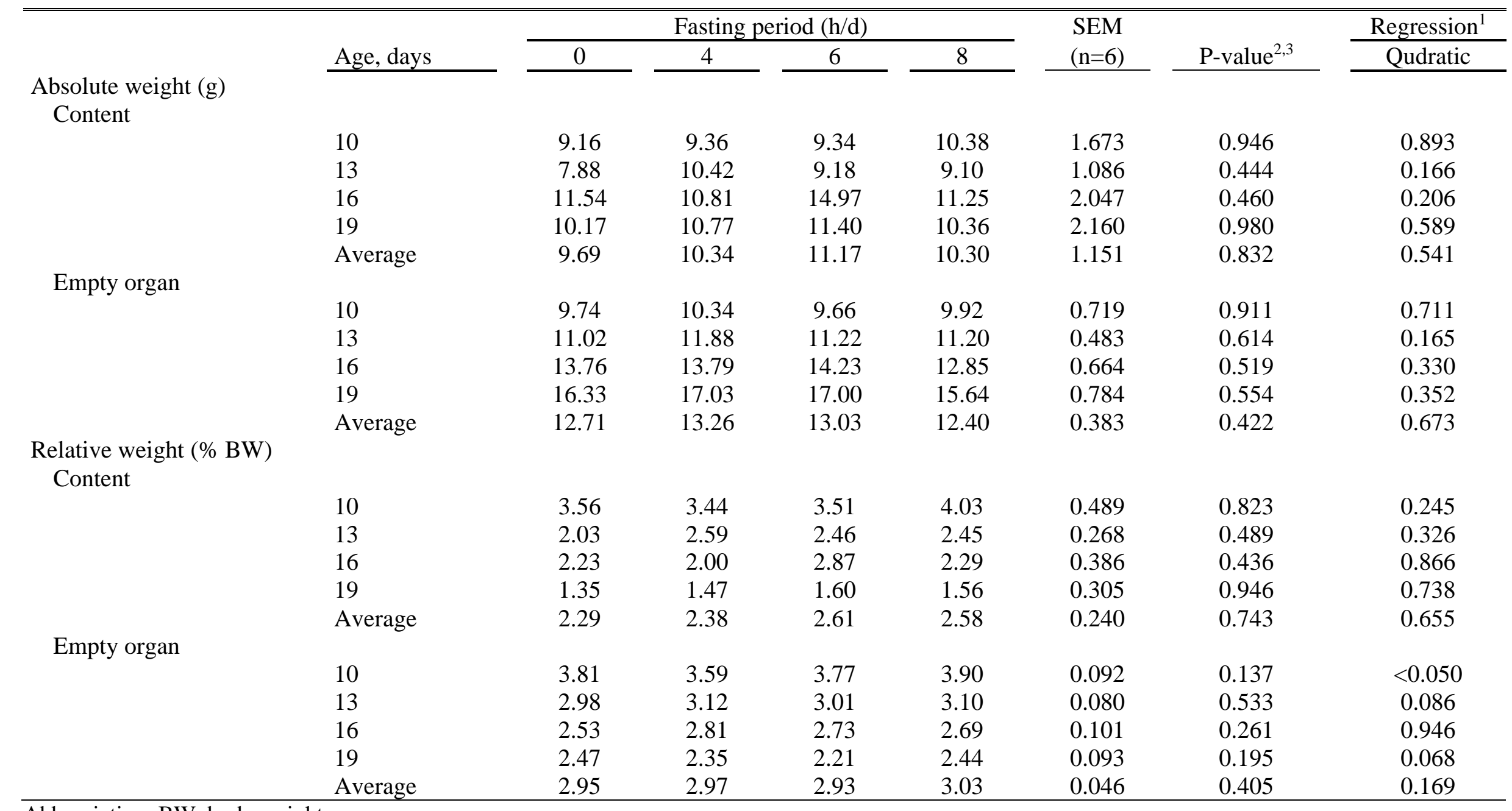

Abbreviation: BW, body weight

${ }^{1}$ The linear effects were not significant for any trait

${ }^{2} \mathrm{P}$-values from the analysis of variance

${ }^{3}$ No interactions between FR length and age of the birds were detected for any of the traits studied 
On $\mathrm{d} 19$, the $\mathrm{pH}$ of the crop increased $(\mathrm{L} ; P<0.05)$ as the length of the fasting period increased, but fasting did not affect gizzard $\mathrm{pH}$ at any age (Table 9). At this age, the number of Lactobacillus spp. colonies in the crop increased $(\mathrm{L} ; P<0.05)$ as the length of the fasting period increased (Table 10).

Table 9. Effects of the length of the fasting period on crop and gizzard $\mathrm{pH}^{1}$. Experiment 1.

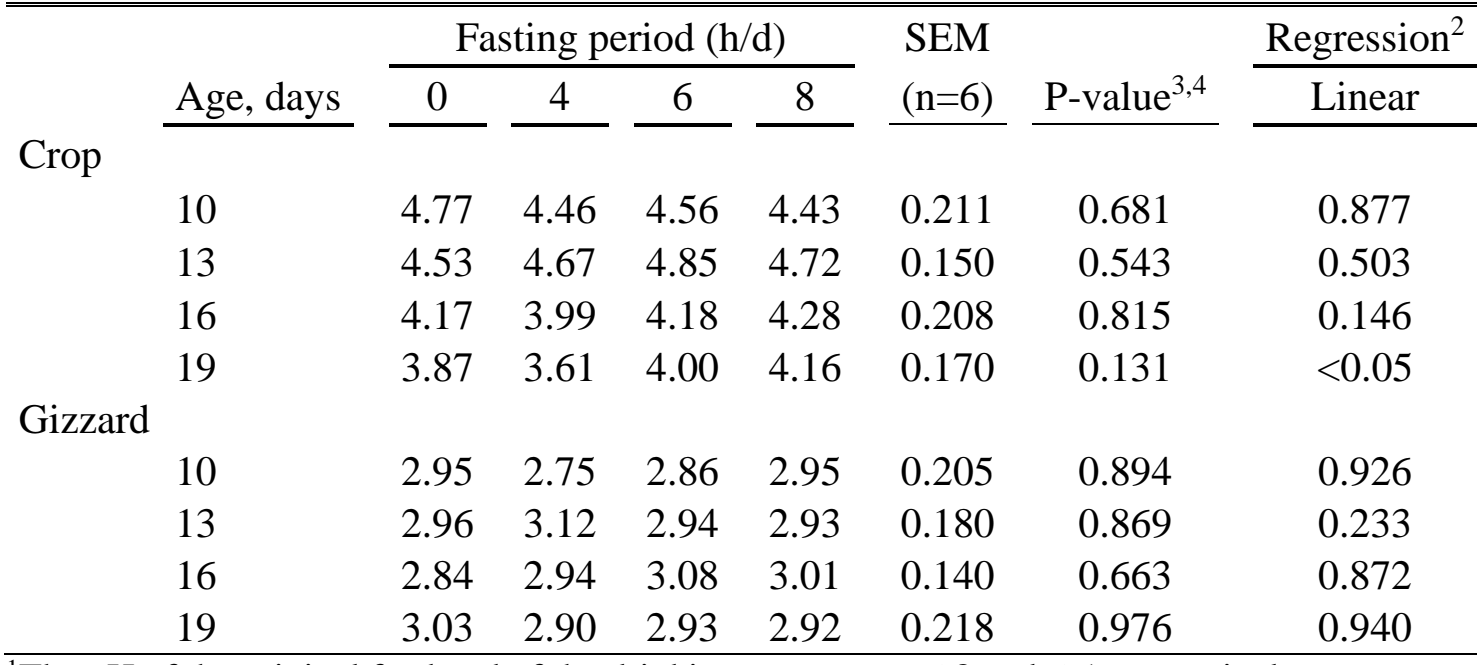

${ }^{1}$ The $\mathrm{pH}$ of the original feed and of the drinking water were 6.8 and 6.5 , respectively

${ }^{2}$ The quadratic effects were not significant for any trait

${ }^{3} \mathrm{P}$-values from the analysis of variance

${ }^{4}$ No interaction between FR length and age of the birds were detected for any of the traits studied

Table 10. Effects of the length of the fasting period on Lactobacillus spp. count (log cfu/g of digesta) in the crop content at 19 days of age. Experiment 1.

\begin{tabular}{|c|c|c|c|c|c|c|}
\hline \multicolumn{4}{|c|}{ Fasting period $(\mathrm{h} / \mathrm{d})$} & \multirow{2}{*}{$\begin{array}{l}\text { SEM } \\
(\mathrm{n}=6)\end{array}$} & \multirow{2}{*}{ P-value ${ }^{1}$} & Regression $^{2}$ \\
\hline 0 & 4 & 6 & 8 & & & Linear \\
\hline 5.28 & 5.97 & 6.36 & 6.35 & 0.318 & 0.086 & $<0.050$ \\
\hline
\end{tabular}

${ }^{1} \mathrm{P}$-values from the analysis of variance

${ }^{2}$ The quadratic effect was not significant 


\subsection{Experiment 2}

\subsubsection{Experiment 2. Essay 1: Growth performance}

Mortality was low $(0.35 \%)$ and not related to treatment. An increase in the length of the fasting period from 0 to $8 \mathrm{~h}$ per day hindered FCR (L; P $<0.001)$. Also, longer fasting decreased FI (L, Q; P < 0.001) and BW gain (L, Q; P < 0.001), but the differences observed were significant only when the FR period lasted for $6 \mathrm{~h}$ or more (Table 11).

Table 11. Effects of the length of the feed restriction period on broiler performance from 6 to $14 \mathrm{~d}$ of age $\mathrm{e}^{1,2}$. Experiment 2. Essay 1.

\begin{tabular}{|c|c|c|c|}
\hline & $\begin{array}{c}\text { FI } \\
(\mathrm{g} / \mathrm{d})\end{array}$ & $\begin{array}{l}\text { BW gain } \\
(\mathrm{g} / \mathrm{d})\end{array}$ & $\begin{array}{l}\text { FCR } \\
(\mathrm{g} / \mathrm{g})\end{array}$ \\
\hline \multicolumn{4}{|c|}{ Fasting period $(\mathrm{h} / \mathrm{d})$} \\
\hline 0 & $48.5^{\mathrm{a}}$ & $37.5^{\mathrm{a}}$ & $1.29^{\mathrm{b}}$ \\
\hline 4 & $48.7^{\mathrm{a}}$ & $37.5^{\mathrm{a}}$ & $1.30^{\mathrm{ab}}$ \\
\hline 6 & $47.8^{\mathrm{ab}}$ & $36.2^{\mathrm{b}}$ & $1.31^{\mathrm{a}}$ \\
\hline 8 & $44.8^{\mathrm{b}}$ & $34.1^{\mathrm{c}}$ & $1.31^{\mathrm{a}}$ \\
\hline $\operatorname{SEM}(n=6)$ & 0.408 & 0.407 & 0.007 \\
\hline \multicolumn{4}{|l|}{ Regression } \\
\hline Linear & $<0.001$ & $<0.001$ & $<0.001$ \\
\hline Quadratic & $<0.001$ & $<0.001$ & 0.799 \\
\hline
\end{tabular}

Abbreviations: FI, feed intake; BW, body weight, FCR, feed conversion ratio

${ }^{1}$ All birds were fed the experimental diet ad libitum from 1 to $6 \mathrm{~d}$ of age

${ }^{2}$ The BW of the birds at $6 \mathrm{~d}$ of age was $161.2 \pm 7.9,161.6 \pm 4.5,162.4 \pm 4.2$, and $161.0 \pm 3.9 \mathrm{~g}$ for broilers fasted for $0,4,6$, and $8 \mathrm{~h} / \mathrm{d}$ from 6 to $14 \mathrm{~d}$ of age, respectively, and was similar (P > 0.100) among treatments

\subsubsection{Experiment 2. Essay 2: Gastrointestinal tract traits}

4.2.2.1. Training. The RW of the empty crop $(\mathrm{P}<0.01)$ and of the digesta contents in fresh $(\mathrm{P}<0.05)$ and dry $(\mathrm{P}=0.089)$ bases, were greater for the TR than for the NTR birds (Table 12). Training, however, did not affect the moisture content (\%) or the $\mathrm{pH}$ of the digesta. Training for fasting did not affect any of the gizzard traits studied. 
Table 12. Effects of training and length of the fasting period on selected crop and gizzard traits measured at $14 \mathrm{~d}$ of age, after $60 \mathrm{~min}$ of free access to feed ${ }^{1}$. Experiment 2. Essay 2.

\begin{tabular}{|c|c|c|c|c|c|c|c|c|c|c|c|}
\hline & \multicolumn{2}{|c|}{ Training $^{2}$} & \multirow[b]{2}{*}{$\begin{array}{c}\text { SEM } \\
(\mathrm{n}=18)\end{array}$} & \multicolumn{4}{|c|}{ Fasting period $(\mathrm{h})$} & \multirow[b]{2}{*}{$\begin{array}{c}\text { Pooled } \\
\text { SEM }^{3} \\
\end{array}$} & \multicolumn{3}{|c|}{$\mathrm{P}$-value } \\
\hline & TR & NTR & & 0 & 4 & 6 & 8 & & Training & $\begin{array}{c}\text { Fasting } \\
\text { length }(\mathrm{L})^{4}\end{array}$ & $\begin{array}{c}\text { Training } \times \text { fasting } \\
\text { length }(\mathrm{L})^{5}\end{array}$ \\
\hline BW (g) & 491 & 502 & & 506 & 503 & 491 & 489 & & & & \\
\hline \multicolumn{12}{|l|}{ Crop traits } \\
\hline Empty weight (\% BW) & 0.460 & 0.384 & 0.015 & 0.367 & 0.398 & 0.424 & 0.444 & 0.014 & $<0.010$ & 0.079 & 0.686 \\
\hline \multicolumn{12}{|c|}{ Digesta content } \\
\hline Fresh (\% BW) & 2.823 & 2.148 & 0.191 & $0.729^{\mathrm{d}}$ & $1.596^{\mathrm{c}}$ & $2.692^{\mathrm{b}}$ & $3.169^{\mathrm{a}}$ & 0.155 & 0.018 & $<0.001$ & $0.017^{6}$ \\
\hline Dried $(\% \mathrm{BW})$ & 1.032 & 0.797 & 0.103 & $0.236^{\mathrm{d}}$ & $0.614^{\mathrm{c}}$ & $0.929^{b}$ & $1.200^{\mathrm{a}}$ & 0.078 & 0.089 & $<0.001$ & 0.099 \\
\hline Moisture (\%) & 65.6 & 63.9 & 2.511 & 66.5 & 66.0 & 65.2 & 62.5 & 2.456 & 0.524 & 0.451 & 0.462 \\
\hline $\mathrm{pH}^{7}$ & 6.01 & 5.99 & 0.061 & $5.29^{\mathrm{b}}$ & $6.01^{\mathrm{a}}$ & $6.03^{\mathrm{a}}$ & $5.96^{\mathrm{a}}$ & 0.101 & 0.872 & 0.012 & 0.694 \\
\hline \multicolumn{12}{|l|}{ Gizzard traits } \\
\hline Empty weight (\% BW) & 2.66 & 2.63 & 0.082 & 2.61 & 2.69 & 2.68 & 2.57 & 0.067 & 0.949 & 0.362 & 0.976 \\
\hline \multicolumn{12}{|l|}{ Digesta content } \\
\hline Fresh (\% BW) & 1.87 & 1.65 & 0.178 & 1.86 & 1.95 & 1.72 & 1.62 & 0.156 & 0.907 & 0.696 & 0.268 \\
\hline $\mathrm{pH}^{7}$ & 3.18 & 3.17 & 0.120 & 3.24 & 3.01 & 3.08 & 3.35 & 0.113 & 0.874 & 0.145 & 0.459 \\
\hline
\end{tabular}

Abbreviation: BW, body weight

${ }^{1}$ Average of 2 birds per replicate

${ }^{2}$ TR: restricted access to feed daily from 6 to $14 \mathrm{~d}$ of age. NTR: restricted access to feed only on d 14

${ }^{3} \mathrm{n}=6$ for the positive control group fed ad libitum and $\mathrm{n}=12$ for all the remaining groups

${ }^{4} \mathrm{~L}=$ Linear effect. The quadratic effect was not significant $(P>0.10)$

${ }^{5} \mathrm{P}$-values correspond to the comparison of the slopes of the lineal effect of the length of the fasting period in the two set of data (TR vs. NTR)

${ }^{6}$ The interaction between main effects on the fresh content of the crop is presented in figure 10

${ }^{7} \mathrm{The} \mathrm{pH}$ of the original feed and of the drinking water were 6.8 and 6.5 , respectively 
4.2.2.2. Feed restriction. An increase in the length of fasting from 0 to $8 \mathrm{~h}$ tended to increase $(\mathrm{P}=0.079)$ the RW of the empty crop and increased the fresh and dried content of this organ $(\mathrm{L}, \mathrm{P}<0.001)$. The response of the crop content to fasting, depended on training (Figure 10). An increase in the length of the FR period increased the fresh digesta content of the crop in TR birds $(\mathrm{L}, \mathrm{P}<0.001)$ whereas in the NTR birds the effect was significant only when the FR period lasted for $6 \mathrm{~h}$ or more $(\mathrm{L}, \mathrm{P}<0.01$; $\mathrm{Q}, \mathrm{P}<0.001)$. Fasting had no effect on the moisture content of the digesta but increased crop $\mathrm{pH}(\mathrm{L}, \mathrm{P}<0.05)$. Fasting did not affect any of the gizzard traits studied.

Figure 10. Influence of the length of the fasting period on the fresh content of the crop (\% BW) in trained (A) and non-trained (B) birds at $14 \mathrm{~d}$ of age $(\mathrm{n}=6)$. Data measured $60 \mathrm{~min}$ after the start of the feeding period. P-values ( $\mathrm{L}=$ Linear; $\mathrm{Q}=$ Quadratic) correspond to data from the regression analysis. Experiment 2. Essay 2.

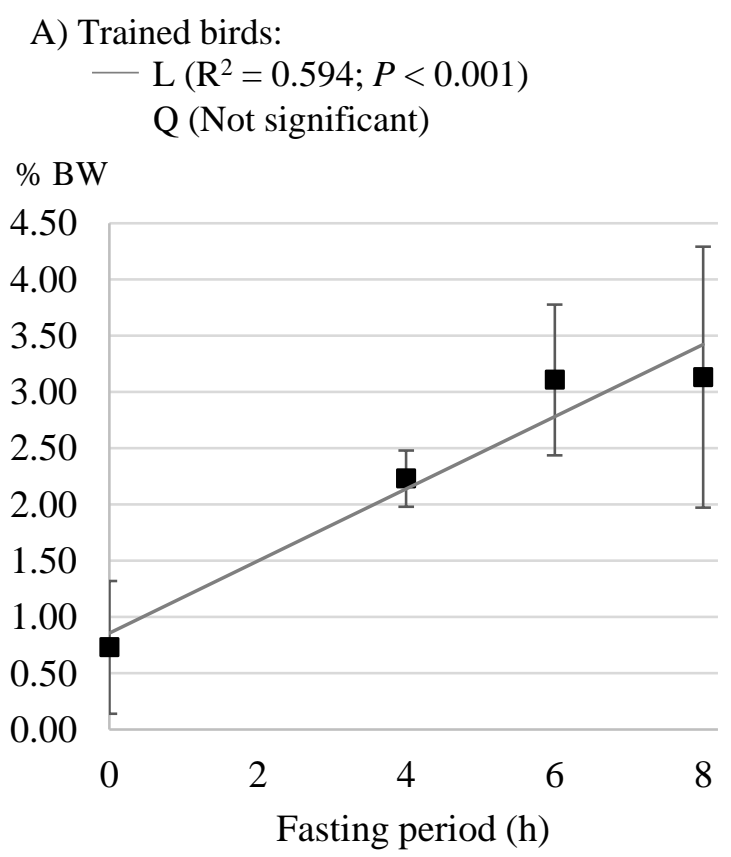

B) Non-trained birds:

$-\mathrm{L}\left(\mathrm{R}^{2}=0.555 ; P<0.01\right)$

$\ldots \mathrm{Q}\left(\mathrm{R}^{2}=0.635 ; P<0.001\right)$

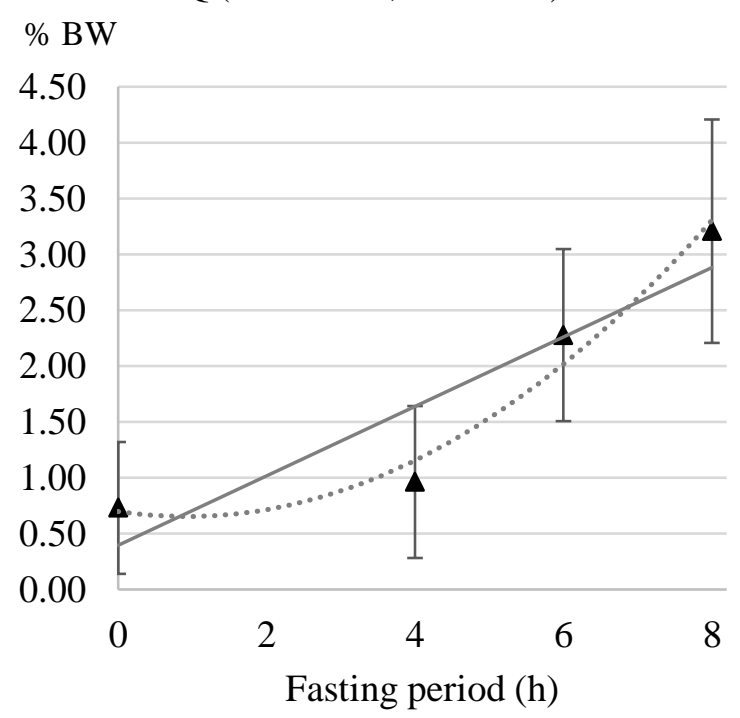




\subsubsection{Experiment 2. Essay 3: Digesta retention in crop and gizzard}

No interactions between training and the length of the fasting period were detected for any of the traits studied and consequently, only main effects are presented.

4.2.3.1. Crop traits. The RW of the fresh and dried contents of the crop were greater in the TR than in the NTR birds $(P<0.05$, Figure 11a) and increased with the length of the fasting period $(P<0.001$, Figure $11 \mathrm{~b})$. However, the retention time of the digesta in the crop varied with the length of the FR $(P<0.001$ for the interaction with time after feed removal). Crop contents after 60 min of full feeding increased with the fasting period and then decreased with time after feed removal and in fact, no contents were found in the crop at $2 \mathrm{~h}$ (broilers fasted for 0,4 , and $6 \mathrm{~h}$ ) or $3 \mathrm{~h}$ (broilers fasted for $8 \mathrm{~h}$ ) after feed removal. Crop $\mathrm{pH}$ was not affected by the fasting strategy applied but decreased from 0 to $4 \mathrm{~h}$ after feed removal $(P<0.001$; Figure 12). 
Figure 11. Influence of training (a) and length of the fasting period (b) on the fresh and dried content of the crop from 0 to $4 \mathrm{~h}$ after feed removal at $14 \mathrm{~d}$ of age. Data presented as mean values \pm SD per treatment. Experiment 2. Essay 3 .

a) Training:
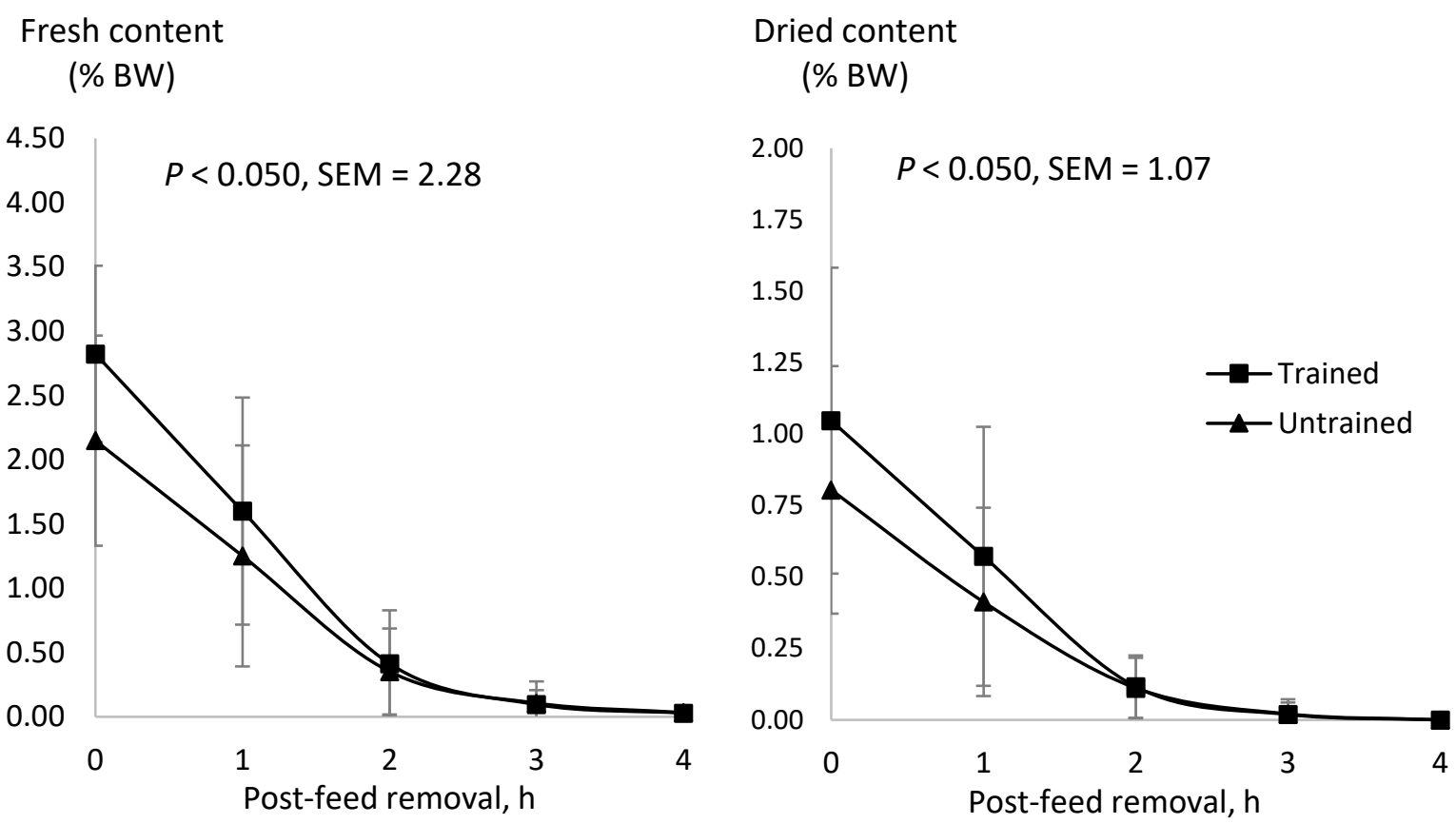

b) Fasting period:

Fresh content

(\% BW)

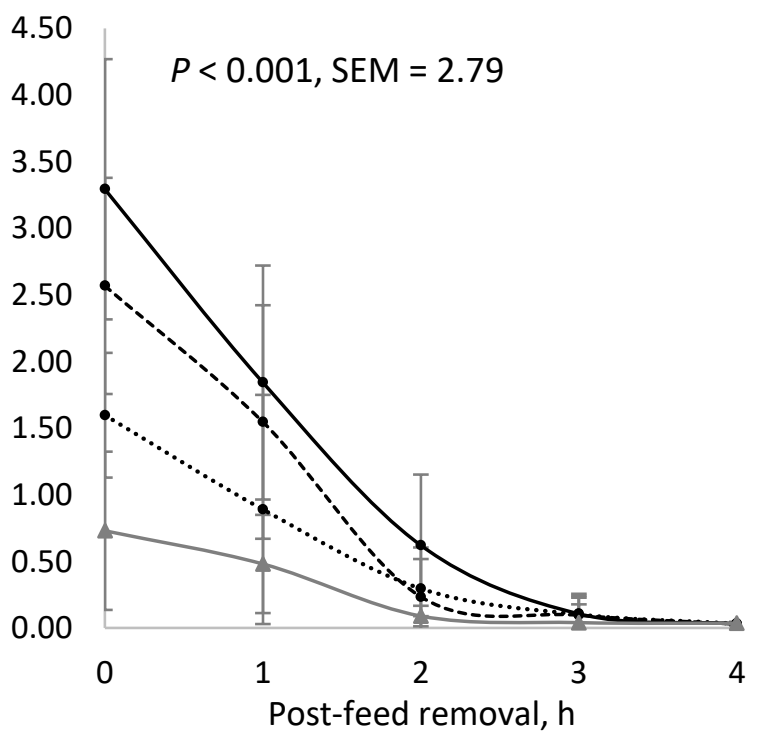

Dried content

(\% BW)

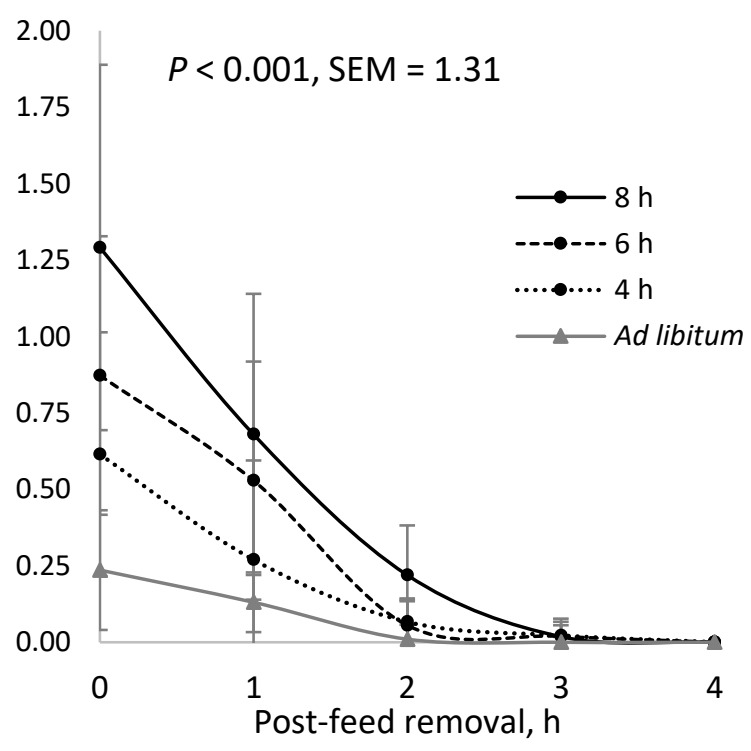


Figure 12. Influence of training (a) and length of the fasting period (b) on crop pH from 0 to $4 \mathrm{~h}$ after feed removal at $14 \mathrm{~d}$ of age. Data presented as mean values \pm SD per treatment. Experiment 2. Essay 3.
a) Training:
b) Fasting period:
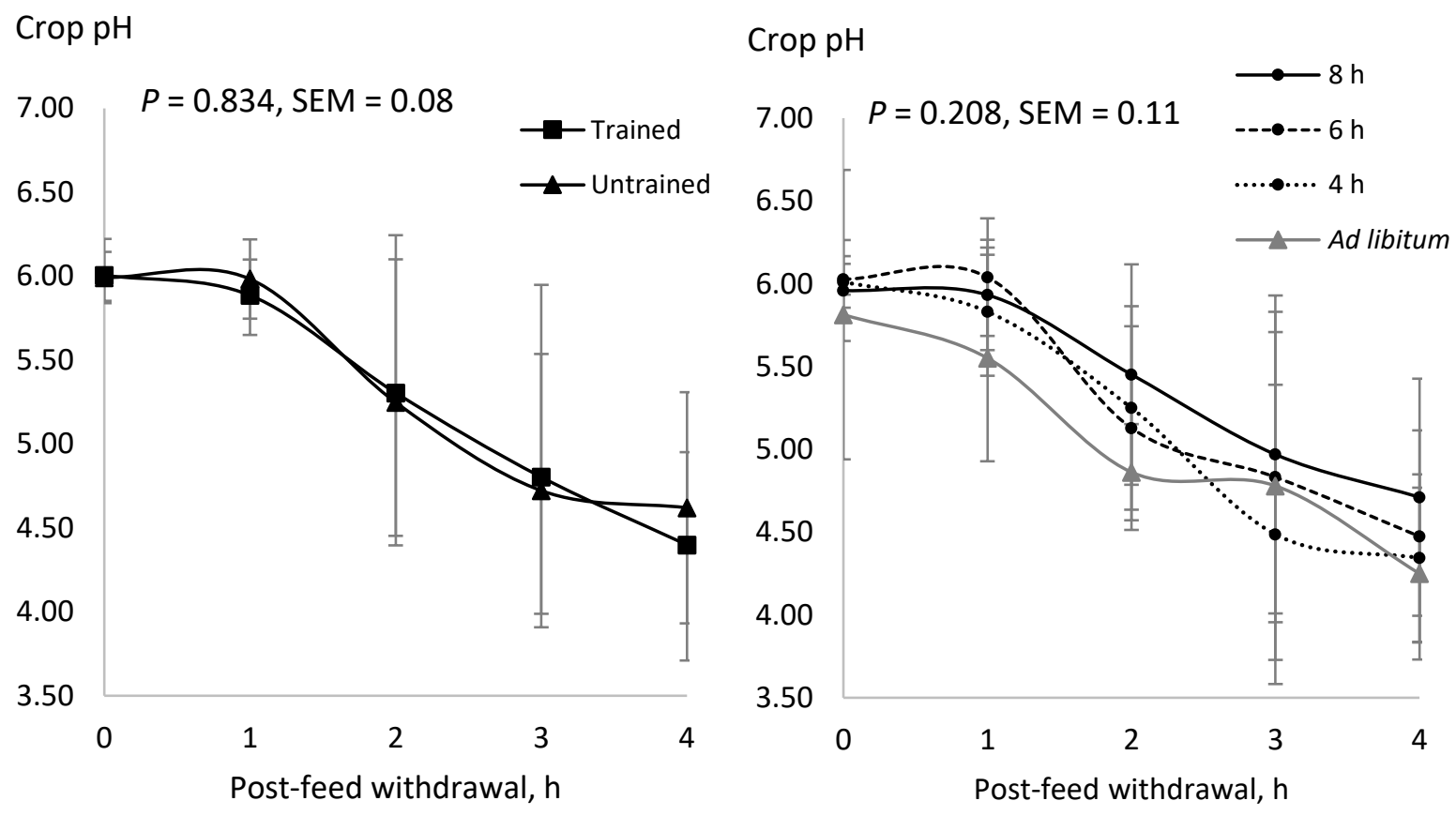

4.2.3.2. Gizzard traits. In relative terms, the gizzard contents were greater $(P<0.05)$ in TR than in NTR birds, an effect that was evident after 60 min of full feeding and at $2 \mathrm{~h}$ after feed removal but disappeared thereafter $(P<0.05$ for the interaction with time after feed removal; Figure 13a). However, substantial amounts of digesta were still present in the gizzard, irrespective of the length of the length of the FR applied, $4 \mathrm{~h}$ after feed deprivation, (Figure 13b). Gizzard $\mathrm{pH}$ was not affected by fasting strategy applied but decreased from 0 to $4 \mathrm{~h}$ after feed removal $(P<0.05$; Figure 14$)$. 
Figure 13. Influence of training (a) and length of the fasting period (b) on the fresh content of the gizzard (\% BW) from 0 to $4 \mathrm{~h}$ after feed removal at $14 \mathrm{~d}$ of age. Data presented as mean values \pm SD per treatment. Experiment 2. Essay 3 .
a) Training:
b) Fasting period:
Fresh content
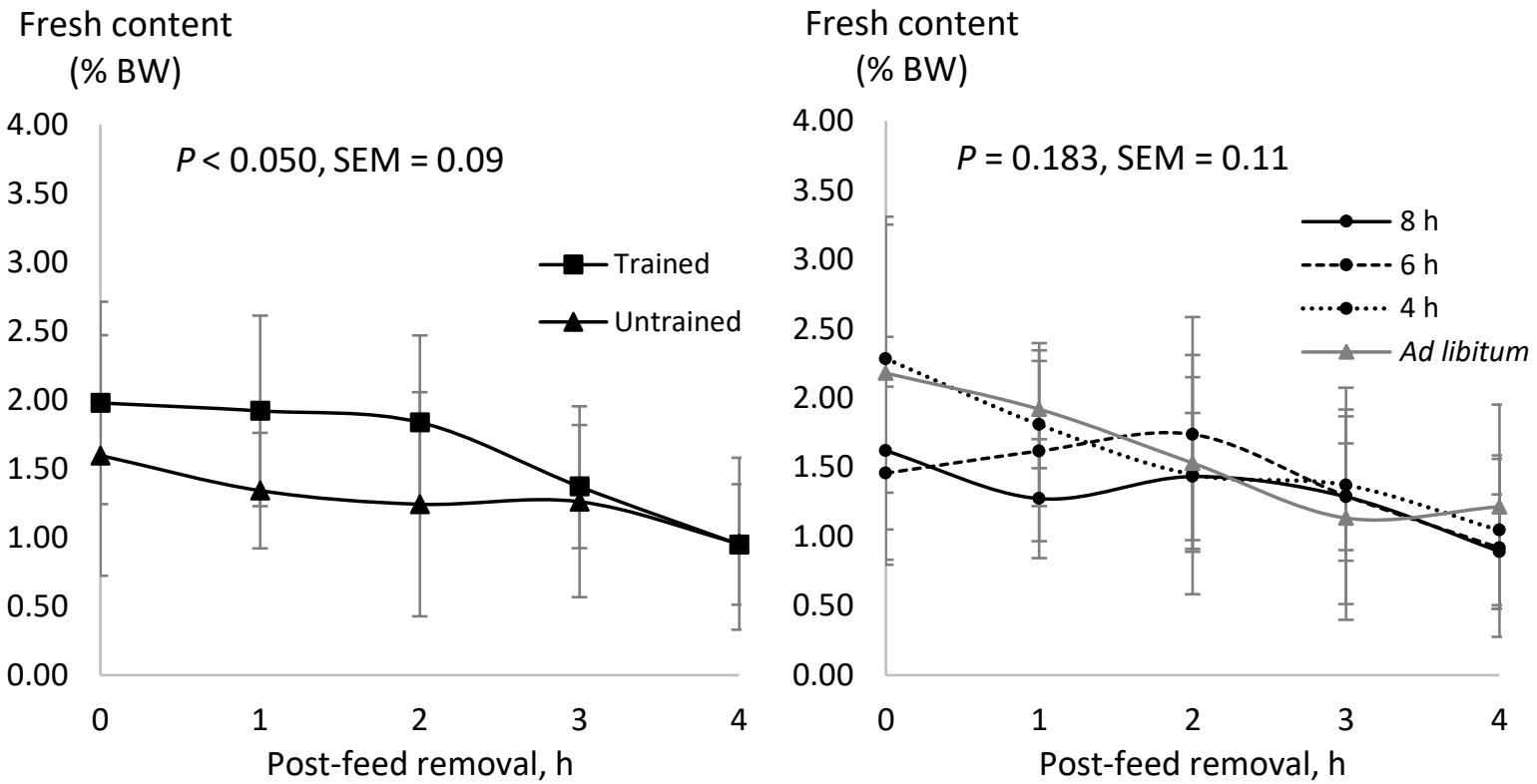

Figure 14. Influence of training (a) and length of the fasting period (b) on gizzard $\mathrm{pH}$ from 0 to $4 \mathrm{~h}$ after feed removal at $14 \mathrm{~d}$ of age. Data presented as mean values \pm SD per treatment. Experiment 2. Essay 3.
a) Training:
b) Fasting period:
Gizzard pH

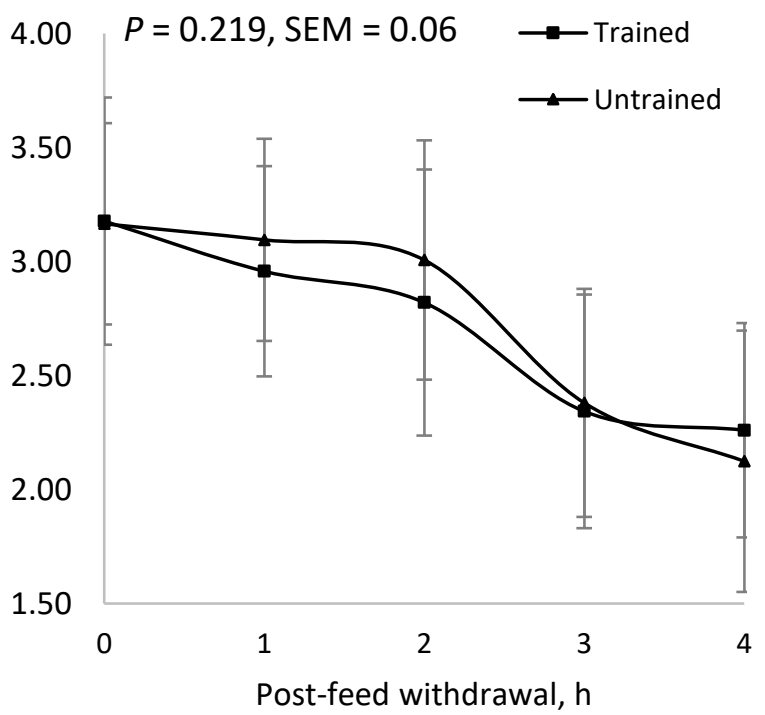
Gizzard pH

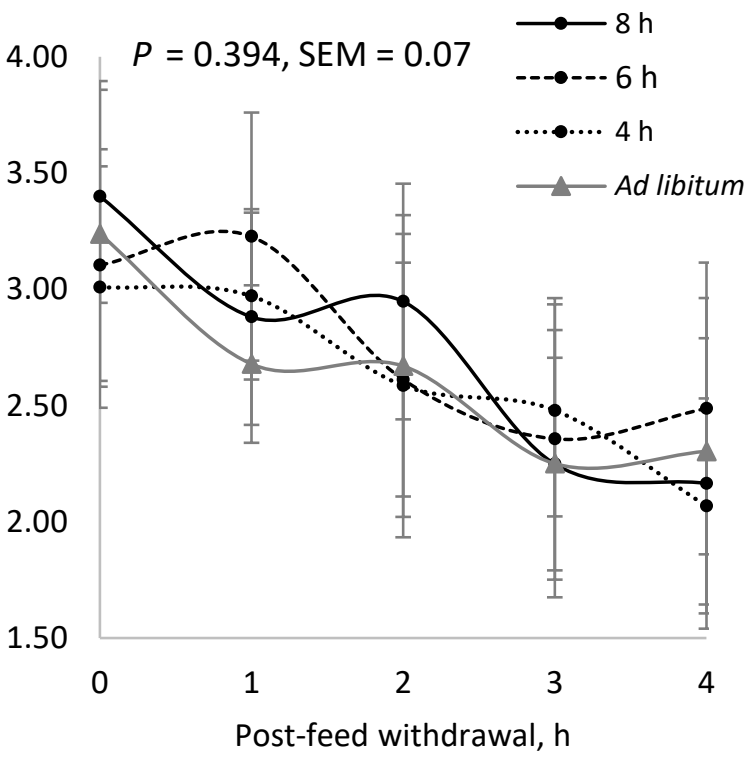




\subsection{Experiment 3}

\subsubsection{Growth performance}

Mortality was low (1.67\% for the Cobb-48 and $0.83 \%$ for the Cobb-24 and Hubbard-24 birds) and not related to treatment. No interactions between main effects were detected for any of the variables studied and consequently, only main effects are presented (Table 13).

4.3.1.1. Type of bird. Feed Intake $(\mathrm{P}<0.001)$ and $\mathrm{BW}$ gain $(\mathrm{P}<0.001)$ were higher for the Cobb-24 birds than for the Cobb-48 birds, and greater $(\mathrm{P}<0.001)$ for both than for the Hubbard-24 birds. Independent of the HW, the Cobb broilers had better FCR than the Hubbard broilers $(\mathrm{P}<0.001)$.

4.3.1.2. Feed restriction. An increase in the length of the fasting period from 4 to 8 h/d, decreased FI (55.6 vs. 48.2 g/d, P < 0.001) and BW gains $(34.2$ vs. 29.0 g/d, P < $0.01)$ and tended to impair the FCR (1.63 vs. $1.67 \mathrm{~g} / \mathrm{g}, \mathrm{P}=0.054)$ of the birds.

\subsubsection{Gastrointestinal tract traits}

No interactions between type of broiler and length of the FR period were detected on any of the GIT traits studied and therefore, only main effects are presented.

4.3.2.1. Type of bird. In absolute terms ( $\mathrm{g})$, the weights of the empty crop (P < $0.05)$, empty gizzard $(\mathrm{P}<0.01)$, and SI $(\mathrm{P}<0.01)$, were greater for Cobb-24 than for Hubbard-24, with Cobb-48 birds being intermediate (Table 14). In relative terms (\% BW), however, type of broiler did not affect organ weights.

Broiler type did not affect the moisture (\%) or the digesta content of the crop in absolute terms. Gizzard content, however, was greater $(\mathrm{P}<0.01)$ in Cobb-24 than in Hubbard-24 birds, with Cobb-48 birds being intermediate (Table 15). Type of broiler did 
not affect $\mathrm{pH}$, number of Lactobacillus spp. colonies, or lactic acid concentration of the crop content (Table 16). Gizzard pH was lower $(\mathrm{P}<0.05)$ in Cobb birds, independent of the length of the HW, than in Hubbard birds.

4.3.2.2. Feed restriction. An increase in fasting from 4 to $8 \mathrm{~h}$, increased $(P<0.001)$ the weight of the empty crop in absolute and relative terms (Table 14). The length of the FR period had no effects on the weight of the gizzard or of the SI in absolute terms. In relative terms, however, the weight of the empty gizzard increased as the length of the FR period increased $(\mathrm{P}<0.05)$.

An increase in the length of the FR period from 4 to $8 \mathrm{~h}$ increased $(\mathrm{P}<0.001)$ the contents of the crop but did not affect the weight of the gizzard contents (Table 15). The number of Lactobacillus spp. colonies $(\mathrm{P}<0.01)$ and the concentration of lactic acid $(\mathrm{P}$ $<0.05$ ) in the crop, increased as the length of the fasting period increased (Table 16). As a result, the $\mathrm{pH}$ of the crop tended to decrease with increases in the length of the fasting period $(\mathrm{P}=0.093)$. Gizzard $\mathrm{pH}$, however, was not affected. 
Table 13. Effects of type of broiler and length of the feed restriction period ${ }^{1}(\mathrm{FR})$ on growth performance of broilers from 7 to 21 days of age ${ }^{2}$. Experiment 3 .

\begin{tabular}{|c|c|c|c|c|}
\hline & $\begin{array}{l}\text { FR } \\
\text { (h) }\end{array}$ & $\begin{array}{c}\text { FI } \\
(\mathrm{g} / \mathrm{d})\end{array}$ & $\begin{array}{l}\text { BW gain } \\
(\mathrm{g} / \mathrm{d})\end{array}$ & $\begin{array}{l}\text { FCR } \\
\text { (g/g) }\end{array}$ \\
\hline \multirow{2}{*}{\multicolumn{5}{|c|}{$\begin{array}{l}\text { Type of broiler } \\
\text { Cobb- } 24\end{array}$}} \\
\hline & & & & \\
\hline & 4 & 61.0 & 38.3 & 1.59 \\
\hline & 8 & 53.9 & 32.7 & 1.65 \\
\hline \multicolumn{5}{|l|}{ Cobb-48 } \\
\hline & 4 & 55.0 & 34.3 & 1.60 \\
\hline & 8 & 47.9 & 29.4 & 1.63 \\
\hline \multicolumn{5}{|l|}{ Hubbard-24 } \\
\hline & 4 & 50.8 & 29.9 & 1.70 \\
\hline & 8 & 42.8 & 24.9 & 1.72 \\
\hline \multicolumn{5}{|l|}{ Main effects } \\
\hline \multicolumn{5}{|l|}{ Type of broiler } \\
\hline Cobb-24 & & $57.5^{\mathrm{a}}$ & $35.5^{\mathrm{a}}$ & $1.62^{b}$ \\
\hline Cobb-48 & & $51.5^{\mathrm{b}}$ & $31.9^{\mathrm{b}}$ & $1.62^{\mathrm{b}}$ \\
\hline Hubbard-24 & & $46.8^{\mathrm{c}}$ & $27.4^{\mathrm{c}}$ & $1.71^{\mathrm{a}}$ \\
\hline \multicolumn{5}{|l|}{$\mathrm{FR}, \mathrm{h}$} \\
\hline 4 & & 55.6 & 34.2 & 1.63 \\
\hline 8 & & 48.2 & 29.0 & 1.67 \\
\hline $\mathrm{SEM}^{4}$ & & 1.68 & 0.92 & 0.026 \\
\hline Type of broiler & & $<0.001$ & $\begin{array}{c}\text { P-value } \\
<0.001\end{array}$ & $<0.001$ \\
\hline FR & & $<0.001$ & $<0.010$ & 0.054 \\
\hline Type of broiler $\times$ FR & & 0.822 & 0.825 & 0.968 \\
\hline
\end{tabular}

Abbreviation: FI, feed intake; BW, body weight; FCR, feed conversion ratio

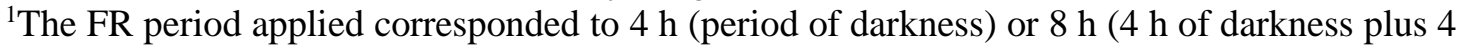
extra hours of physical restriction)

${ }^{2} \mathrm{BW}$ at $7 \mathrm{~d}$ of age was $152 \pm 4.1,139 \pm 4.9$, and $124 \pm 5.2 \mathrm{~g}$, for Cobb-24, Cobb-48, and Hubbard-24 birds, respectively, and was similar $(P>0.100)$ for the two fasting periods within each broiler type

${ }^{3}$ Hatching window of 24 (Cobb-24), 48 (Cobb-48), and 24 (Hubbard-24) hours. The BW of the chicks were $40.7 \pm 0.87,35.1 \pm 1.33$, and $39.3 \pm 1.13 \mathrm{~g}$ at arrival to the experimental station after a 33,57 , and $33 \mathrm{~h}$ without access to feed and water, respectively

${ }^{4}$ Six replicates with 10 birds each per treatment 
Table 14. Effects of type of broiler and length of the feed restriction period ${ }^{1}(\mathrm{FR})$ on the absolute $(\mathrm{g})$ and relative (\% BW) weight of selected organs of the gastrointestinal tract at $21 \mathrm{~d}$ of age. Experiment 3.

\begin{tabular}{|c|c|c|c|c|c|c|c|}
\hline & \multirow{2}{*}{$\begin{array}{l}\text { FR } \\
\text { (h) }\end{array}$} & \multicolumn{2}{|c|}{ Crop, empty } & \multicolumn{2}{|c|}{ Gizzard, empty } & \multicolumn{2}{|c|}{ Small intestine $^{3}$, full } \\
\hline & & $(g)$ & $(\% \mathrm{BW})$ & (g) & $(\% \mathrm{BW})$ & $(\mathrm{g})$ & $(\% \mathrm{BW})$ \\
\hline \multicolumn{8}{|l|}{ Type of broiler ${ }^{2}$} \\
\hline & 4 & 2.42 & 0.386 & 21.2 & 3.36 & 49.6 & 7.87 \\
\hline & 8 & 3.00 & 0.487 & 19.9 & 3.21 & 49.7 & 8.01 \\
\hline \multicolumn{8}{|l|}{ Cobb-48 } \\
\hline & 4 & 2.27 & 0.412 & 18.9 & 3.44 & 47.8 & 8.72 \\
\hline & 8 & 2.73 & 0.502 & 18.3 & 3.35 & 47.7 & 8.68 \\
\hline \multicolumn{8}{|l|}{ Hubbard-24 } \\
\hline & 4 & 2.13 & 0.432 & 17.0 & 3.45 & 40.8 & 8.26 \\
\hline & 8 & 2.71 & 0.531 & 16.7 & 3.26 & 41.2 & 8.06 \\
\hline \multicolumn{8}{|l|}{ Main effects } \\
\hline \multicolumn{8}{|l|}{ Type of broiler } \\
\hline Cobb-24 & & $2.72^{\mathrm{a}}$ & 0.436 & $20.54^{\mathrm{a}}$ & 3.29 & $49.6^{\mathrm{a}}$ & 7.93 \\
\hline Cobb-48 & & $2.50^{\mathrm{ab}}$ & 0.457 & $18.63^{\mathrm{ab}}$ & 3.40 & $47.7^{\mathrm{a}}$ & 8.70 \\
\hline Hubbard-24 & & $2.42^{\mathrm{b}}$ & 0.481 & $16.87^{\mathrm{b}}$ & 3.35 & $41.0^{\mathrm{b}}$ & 8.16 \\
\hline \multicolumn{8}{|l|}{$\mathrm{FR}, \mathrm{h}$} \\
\hline 4 & & 2.27 & 0.410 & 19.05 & 3.42 & 46.1 & 8.28 \\
\hline 8 & & 2.81 & 0.487 & 18.31 & 3.27 & 46.2 & 8.25 \\
\hline $\mathrm{SEM}^{4}$ & & 0.114 & 0.022 & 0.573 & 0.073 & 1.811 & 0.265 \\
\hline Type of broiler & & 0.044 & 0.133 & $<0.001$ & 0.328 & $<0.001$ & 0.122 \\
\hline FR & & $<0.001$ & $<0.001$ & 0.121 & 0.023 & 0.934 & 0.882 \\
\hline Type of broiler $\times$ FR & & 0.838 & 0.280 & 0.724 & 0.810 & 0.987 & 0.822 \\
\hline \multicolumn{8}{|c|}{$\begin{array}{l}\text { Abbreviation: BW, body weight } \\
{ }^{1} \text { The FR period applied corresponded to } 4 \mathrm{~h} \text { (period of darkness) or } 8 \mathrm{~h}(4 \mathrm{~h} \text { of darkness plus } 4 \text { extra hours of physical restriction) } \\
{ }^{2} \text { Hatching window of } 24(\text { Cobb- } 24), 48(\mathrm{Cobb}-48) \text {, and } 24(\text { Hubbard- } 24) \text { hours. The } \mathrm{BW} \text { of the chicks were } 40.7 \pm 0.87,35.1 \pm 1.33 \text {, and } 39.3 \pm 1.13 \mathrm{~g} \text { at } \\
\text { arrival to the experimental station after a } 33,57 \text {, and } 33 \mathrm{~h} \text { without access to feed and water, respectively } \\
{ }^{3} \text { Duodenum, jejunum, and ileum }\end{array}$} \\
\hline
\end{tabular}


Table 15. Effects of type of broiler and length of the feed restriction period ${ }^{1}$ (FR) on the digesta content of the crop and the gizzard at $21 \mathrm{~d}$ of age. Experiment 3.

\begin{tabular}{|c|c|c|c|c|c|c|c|c|}
\hline & \multirow{3}{*}{$\begin{array}{l}\text { FR } \\
\text { (h) }\end{array}$} & \multicolumn{5}{|c|}{ Crop digesta } & \multirow{2}{*}{\multicolumn{2}{|c|}{$\begin{array}{c}\text { Gizzard digesta } \\
\text { Fresh }\end{array}$}} \\
\hline & & \multicolumn{2}{|c|}{ Fresh } & \multicolumn{2}{|c|}{ Dried } & \multirow{2}{*}{$\begin{array}{c}\text { Moisture } \\
(\%)\end{array}$} & & \\
\hline & & $(\mathrm{g})$ & $(\% \mathrm{BW})$ & $(\mathrm{g})$ & $(\% \mathrm{BW})$ & & $(\mathrm{g})$ & $(\% \mathrm{BW})$ \\
\hline \multicolumn{9}{|l|}{$\begin{array}{l}\text { Type of broiler } \\
\text { Cobb-24 }\end{array}$} \\
\hline & 4 & 4.24 & 0.662 & 1.31 & 0.212 & 69.0 & 9.64 & 1.52 \\
\hline & 8 & 10.59 & 1.693 & 3.94 & 0.628 & 63.2 & 10.02 & 1.62 \\
\hline \multicolumn{9}{|l|}{ Cobb-48 } \\
\hline & 4 & 4.64 & 0.841 & 1.74 & 0.315 & 62.9 & 9.32 & 1.69 \\
\hline & 8 & 9.01 & 1.657 & 3.26 & 0.602 & 62.9 & 9.73 & 1.79 \\
\hline \multicolumn{9}{|l|}{ Hubbard-24 } \\
\hline & 4 & 3.33 & 0.669 & 1.40 & 0.269 & 60.1 & 7.64 & 1.54 \\
\hline & 8 & 9.97 & 1.966 & 3.73 & 0.769 & 62.7 & 8.53 & 1.66 \\
\hline \multicolumn{9}{|l|}{ Main effects } \\
\hline \multicolumn{9}{|l|}{ Type of broiler } \\
\hline Cobb-24 & & 7.41 & 1.178 & 2.62 & 0.420 & 66.1 & $9.83^{\mathrm{a}}$ & 1.57 \\
\hline Cobb-48 & & 6.83 & 1.249 & 2.50 & 0.458 & 62.9 & $9.53^{\mathrm{ab}}$ & 1.74 \\
\hline Hubbard-24 & & 6.65 & 1.317 & 2.56 & 0.519 & 61.4 & $8.09^{\mathrm{b}}$ & 1.60 \\
\hline \multicolumn{9}{|l|}{$\mathrm{FR}, \mathrm{h}$} \\
\hline 4 & & 4.07 & 0.724 & 1.48 & 0.265 & 64.0 & 8.87 & 1.59 \\
\hline 8 & & 9.86 & 1.772 & 3.64 & 0.666 & 62.9 & 9.43 & 1.69 \\
\hline $\mathrm{SEM}^{3}$ & & 1.476 & 0.250 & 0.562 & 0.097 & 2.25 & 0.452 & 0.084 \\
\hline Type of broiler & & 0.864 & 0.862 & 0.976 & 0.599 & 0.117 & $<0.010$ & 0.105 \\
\hline FR & & $<0.001$ & $<0.001$ & $<0.001$ & $<0.001$ & 0.569 & 0.139 & 0.135 \\
\hline Type of broiler $\times$ FR & & 0.626 & 0.648 & 0.589 & 0.550 & 0.180 & 0.820 & 0.992 \\
\hline
\end{tabular}


Table 16. Effects of type of broiler and length of the feed restriction period ${ }^{1}$ (FR) on the Lactobacillus spp. count (log cfu/g of digesta), lactic acid concentration ( $\mu \mathrm{mol} / \mathrm{g}$ of digesta), and $\mathrm{pH}$ of the crop, and on gizzard $\mathrm{pH}$. Experiment 3.

\begin{tabular}{|c|c|c|c|c|c|}
\hline & \multirow{2}{*}{$\begin{array}{l}\text { FR } \\
\text { (h) }\end{array}$} & \multicolumn{3}{|c|}{ Crop content } & \multirow[b]{2}{*}{ Gizzard pH } \\
\hline & & Lactobacillus spp. & Lactic acid & $\mathrm{pH}^{3}$ & \\
\hline \multicolumn{6}{|l|}{ Type of broiler ${ }^{2}$} \\
\hline \multicolumn{6}{|l|}{ Cobb-24 } \\
\hline & 4 & 5.33 & 70.8 & 4.16 & 1.93 \\
\hline & 8 & 6.09 & 107.7 & 4.06 & 1.96 \\
\hline \multicolumn{6}{|l|}{ Cobb-48 } \\
\hline & 4 & 5.29 & 50.6 & 4.38 & 1.95 \\
\hline & 8 & 5.98 & 86.8 & 4.12 & 2.02 \\
\hline \multicolumn{6}{|l|}{ Hubbard-24 } \\
\hline & 4 & 5.59 & 50.0 & 4.33 & 2.19 \\
\hline & 8 & 6.93 & 85.3 & 4.15 & 2.33 \\
\hline \multicolumn{6}{|l|}{ Main effects } \\
\hline \multicolumn{6}{|l|}{ Type of broiler } \\
\hline Cobb-24 & & 5.71 & 89.2 & 4.11 & $1.94^{\mathrm{b}}$ \\
\hline Cobb-48 & & 5.63 & 68.7 & 4.25 & $1.98^{\mathrm{b}}$ \\
\hline Hubbard-24 & & 6.26 & 67.6 & 4.24 & $2.26^{\mathrm{a}}$ \\
\hline \multicolumn{6}{|l|}{$\mathrm{FR}, \mathrm{h}$} \\
\hline 4 & & 5.40 & 57.1 & 4.29 & 2.02 \\
\hline 8 & & 6.33 & 93.3 & 4.11 & 2.10 \\
\hline \multicolumn{2}{|l|}{$\mathrm{SEM}^{4}$} & 0.233 & 9.90 & 0.127 & 0.117 \\
\hline \multicolumn{2}{|l|}{ Type of broiler } & 0.112 & 0.254 & 0.445 & 0.022 \\
\hline \multicolumn{2}{|l|}{ FR } & $<0.010$ & 0.034 & 0.093 & 0.442 \\
\hline \multicolumn{2}{|c|}{ Type of broiler $\times$ FR } & 0.363 & 0.923 & 0.817 & 0.891 \\
\hline $\begin{array}{l}{ }^{1} \text { The FR period applie } \\
\text { hours of physical restri } \\
{ }^{2} \text { Hatching window of } \\
\text { chicks were } 40.7 \pm 0.8 \\
33,57 \text {, and } 33 \mathrm{~h} \text { withou } \\
{ }^{3} \text { The pH of the origin } \\
{ }^{4} \text { Six replicates with } 1\end{array}$ & $\begin{array}{l}\text { ed cor } \\
\text { iction) } \\
\text { f } 24 \text { ( } \\
7,35 . \\
\text { ut acc } \\
\text { al fee } \\
0 \text { bird }\end{array}$ & $\begin{array}{l}\text { ponded to } 4 \mathrm{~h} \text { (period } \\
\text { bb-24), } 48 \text { (Cobb-48) } \\
=1.33 \text {, and } 39.3 \pm 1.13 \\
\text { to feed and water, res } \\
\text { ind of the drinking wat } \\
\text { ach per treatment }\end{array}$ & $\begin{array}{l}\text { darkness) or } 8 \\
\text { nd } 24 \text { (Hubba } \\
\text { at arrival to th } \\
\text { ctively } \\
\text { were } 7.1 \text { and }\end{array}$ & $\begin{array}{l}4 \mathrm{~h} \text { of di } \\
\text { 24) hou } \\
\text { experim } \\
\text { respec }\end{array}$ & $\begin{array}{l}\text { The BW of the } \\
\text { station after a }\end{array}$ \\
\hline
\end{tabular}




\section{GENERAL DISCUSSION}




\section{GENERAL DISCUSSION}

\subsection{Growth performance}

\subsubsection{Feed restriction}

A restriction of the access to feed results usually in a reduction in FI during the adaptation period following the implementation of a fasting strategy (Lewis et al., 2009; Rodrigues and Choct, 2018). In fact, when a fasting program is applied to young birds, growth performance is initially reduced because the capacity of their GIT is limited, resulting in delayed growth (Lewis and Morris, 2006; Farghly et al., 2019). However, the negative impact of FR on growth performance depends on the length of the fasting period as well as the time allowed to the birds to adapt their feeding behavior to the new strategy (Butzen et al., 2013; Dalal, 2016).

The results of the current research showed a clear impairment of growth performance when the FR lasted for $6 \mathrm{~h}$ or more. In fact, compared to AL feeding, a FR period of $8 \mathrm{~h} / \mathrm{d}$ from 7 to $13 \mathrm{~d}$ of age penalized FI by $7.8 \%$ and BW gain by $8.4 \%$ in experiment 1. Similar results were observed in experiment 2 , in which broilers fasted for $8 \mathrm{~h} / \mathrm{d}$ from 6 to $14 \mathrm{~d}$ of age showed a 9.1 and $7.6 \%$ reduction in FI and BW gain, respectively, compared to AL fed broilers. Similar data have been reported by SchweanLardner et al. (2012) who observed that fasting the birds for $7 \mathrm{~h} / \mathrm{d}$ or more, from 7 to 31 d of age, decreased FI and reduced growth rate. However, no effects were observed with shorter FR periods, consistent with the data reported herein. In experiments 1 and 2, broilers fasted for $4 \mathrm{~h} / \mathrm{d}$ showed similar growth performance than AL fed broilers. Furthermore, in experiment 3, an increase in the length of the FR period from 4 to $8 \mathrm{~h} / \mathrm{d}$ reduced FI and BW gain from 7 to $21 \mathrm{~d}$ of age by 13.3 and $15.2 \%$, respectively, independent of broiler growth potential. The information provided suggests that the adaptive mechanism of the broilers to FR strategies, which consists primarily in an extra 
increase in FI immediately before and after the absence of feed availability, could not fully compensate for the nutrient requirements of the birds when the fasting period lasted for $6 \mathrm{~h}$ or more. In addition, compared to broilers fed AL, the early adaptation to the fasting strategy impaired FCR from 6 to $14 \mathrm{~d}$ when the FR period lasts for 6 or $8 \mathrm{~h}$ in experiment 2 (essay 1). Similarly, El-Sagheer and Makled (2005) and Farghly et al. (2019) reported significant impairments on FCR in broilers during the first days after the implementation of FR strategies lasting for 6 or more hours of daily fasting. Probably, the excitement for FI with broilers rushing to feeders at the start of the feeding period observed in birds under fasting conditions (Rodrigues and Choct, 2018; 2019) resulted in more feed wastes and poorer FCR. In experiment 1, however, the numerical increase in FCR observed from 7 to $13 \mathrm{~d}$ of age as the length of the fasting period increased from 0 to $8 \mathrm{~h} / \mathrm{d}$ did not reach significance. A reduced feeder space caused by a higher stocking density is a major aspect interacting with FR (Sahraei, 2012). The slightly lower stocking density in experiment 2 (essay 1) compared to experiment 1 (11 and 12 birds per cage at 13 and $14 \mathrm{~d}$ of age, respectively) might explain differences in significance among research for the negative effects of longer fasting periods on FCR during the adaptation period to the fasting strategy.

The disruption in growth performance observed for the first days after the implementation of a fasting strategy is often followed by a compensatory growth phase (Camacho et al., 2004; Rodrigues and Choct, 2018). In this respect, depending on the age of the birds and the severity of the FR strategy, fasted birds might be able to recover with time from the initial reduction in BW gain (Lewis et al., 2009; Butzen et al., 2013; Svihus et al., 2013). Farghly et al. (2019) reported that the decrease in BW observed in birds fasted for $12 \mathrm{~h} / \mathrm{d}$ from hatch to $21 \mathrm{~d}$ of age, disappeared at $42 \mathrm{~d}$ of age. Also, SchweanLardner et al. (2012) reported that broilers fasted for $10 \mathrm{~h} / \mathrm{d}$ were able to recover with 
time from the initial reduction in growth rate and in fact, an increase in the length of the FR period from 1 to $7 \mathrm{~h} / \mathrm{d}$ resulted in similar BW at $49 \mathrm{~d}$ of age. In experiment 1 , the reduction in $\mathrm{BW}$ gain observed with the increase in the length of the fasting period from 0 to $8 \mathrm{~h} / \mathrm{d}$, applied from 7 to $13 \mathrm{~d}$ of age, disappeared after this age. In this experiment, the FR strategy started when the broilers were $7 \mathrm{~d}$ of age and lasted only $12 \mathrm{~d}$. Possibly, the lower BW observed at $19 \mathrm{~d}$ of age in birds fasted for $6 \mathrm{~h} / \mathrm{d}$ or more, could have been attenuated or even disappeared if the experiment could have lasted for longer. The information provided suggests that birds adapt quickly to FR conditions with age, and that the initial reduction in FI tends to decrease if sufficient time is allowed for broilers to adapt their feeding behavior to the fasting conditions. In this respect, commercial management recommendations by Cobb (2018b) and Ross (2018) suggest that 6 to $8 \mathrm{~h}$ of darkness per day could improve growth performance and feed efficiency of the broilers without any penalty on the BW at slaughter.

\subsubsection{Type of bird}

In experiment 3 , Cobb birds had a feed and water deprivation period after hatch of 33 (HW of $24 \mathrm{~h}$ ) or $57 \mathrm{~h}(\mathrm{HW}$ of $48 \mathrm{~h}$ ) depending on treatment. As a consequence, the $\mathrm{BW}$ of the Cobb chicks at placement in the farm was $40.7 \pm 0.87$ and $35.1 \pm 1.33 \mathrm{~g}$, respectively (a 13.8\% reduction in BW). The low BW of the Cobb-48 chicks was caused primarily by dehydration (Casteel et al., 1994; de Jong et al., 2017). Tong et al. (2015) reported that BW was reduced by $0.13 \%$ for each hour of $\mathrm{HW}$ at the setter. Also, Özlü et al. (2018) observed that compared to $8 \mathrm{~h}$, a residence of 27 and $36 \mathrm{~h}$ in the hatcher resulted in 6.9 and $10.0 \%$ reduction in BW at placement, respectively. In the current research, the delay in growth of the Cobb-48 vs. Cobb-24 birds resulted in 10.1\% lower BW gain from 7 to $21 \mathrm{~d}$ of age. Similarly, Abed et al. (2011) reported that an increase in the delay of the access to feed and water from 32 to $48 \mathrm{~h}$ after hatch, reduced BW gain of the broilers 
from 1 to $21 \mathrm{~d}$ of age by $14.0 \%$. The information provided suggests that prolonged HW periods, which results in a high percentage of chicks suffering severe environmental conditions, causes a BW loss at placement that affects broiler growth during the first weeks of age. Under commercial conditions, inadequate practices, such as poor management at the hatchery with extended transport times might compromise broiler growth (Careghi et al., 2005; Jacobs et al., 2016).

In experiment 3, the BW gain and FCR from 7 to $21 \mathrm{~d}$ of age was 18.7 and $5.6 \%$ better for Cobb than for Hubbard birds, consistent with the objective of current genetic selection programs for these two broiler lines [Cobb 500 (2018a); Hubbard JA757 (2016a)]. Similar data have been reported by Ganzer et al. (2017), Fondevila et al. (2018), and Steenfeldt et al. (2019), comparing the growth performance between fast-growth rate broilers and a slower growth rate strain.

\subsection{Feeding behavior and gastrointestinal tract traits}

\subsubsection{Age of the bird}

Feed intake in broilers is negatively correlated with the length of the fasting period during the first days after the implementation of a FR strategy, in which the birds learn to adapt their feeding behavior to the lack of feed availability (Lewis et al., 2009). In this respect, May and Lott (1992) reported that birds were able to increase FI in anticipation to a period of $12 \mathrm{~h}$ of darkness as soon as two days after the implementation of the FR period. However, there is a lack of information on the effects of age on the early adaptation to shorter FR periods as those proposed by the EU-27 (Council Directive

2007/43/EC). In experiment 1, the fresh and dry digesta contents of the crop in absolute terms, as well as its moisture content, prior to the start of the FR period (4 to $8 \mathrm{~h} / \mathrm{d}$ ) increased as the birds aged from 7 to $19 \mathrm{~d}$ of age. In fact, the effects of fasting on the 
utilization of the crop as a feed storage organ were evident at $10 \mathrm{~d}$ of age, only $3 \mathrm{~d}$ after the start of the fasting period. At this age, the crop digesta content increased as the length of the FR period increased, consistent with data of Svihus et al. (2013), who reported a quick adaptation of the birds to the fasting conditions imposed. Furthermore, the adaptation to FR was maintained during the whole experiment, proving the consistent effects of fasting on crop development and bird feeding behavior. These results suggest that broilers are able to predict the subsequent lack of feed and increase the capacity of their crops to cope with the fasting conditions imposed, improving feed moisturization in the crop with age.

In experiment 1 , the absolute (g) weight of the empty crop increased with age, whereas an opposite effect was observed in relative terms. Similar results were observed for the weight and the fresh content of the gizzard, in agreement with data of Ravindran et al. (2006) and González-Alvarado et al. (2008). The differences observed between absolute and relative terms, on the weight of the two organs of the proximal part of the GIT, are probably related to differences in the rate of growth of organs and tissues with age (Jiménez-Moreno et al., 2019).

Crop $\mathrm{pH}$ depends, at least in part, on the fermentation capability of the microbial population and the concomitant increase in organic fatty acids production in this organ. The fermentation activity of the crop is expected to increase with age (Classen et al., 2016) and consequently, the $\mathrm{pH}$ of the crop might decrease with age, in agreement with the results reported in experiment 1 . Similarly, the $\mathrm{pH}$ of the gizzard is expected to decrease during the first week of life because of the increase in the secretion of hydrochloric acid in the proventriculus as the GIT matures (Mahagna and Nir, 1996). In experiment 1 , however, gizzard $\mathrm{pH}$ was not affected as the birds aged from 7 to $19 \mathrm{~d}$ of age. Nevertheless, the $\mathrm{pH}$ of the gizzard varies widely after this age, depending on factors 
such as the retention time of the digesta in this organ and the amount and chemical characteristics of the original feed (Svihus, 2011).

\subsubsection{Feed restriction}

Crop and gizzard are the main segments of the GIT used by the bird to store and regulate the transit time of the digesta (Classen et al., 2016; Rodrigues and Choct, 2018). Typically, the feeding behavior of broilers fed AL consists in short and frequent approaches to the feed with little utilization of the crop as a storage organ. In experiments 1 and 2, the lowest crop contents were observed in broilers fed AL, confirming that the retention time of the digesta in this organ is markedly low when feed is freely available. Consequently, the function of the crop as a feed storage organ is of limited interest in these birds (Shires et al., 1987; Buyse et al. 1993). However, the implementation of a fasting strategy via manipulation of the light program or by physical restriction to the access to feed increases the role of the crop for feed storage (Classen et al., 2016; Rodrigues and Choct, 2018). When the broilers are allowed to learn and adapt their GIT physiology to the lack of feed, broilers modify quickly the feeding behavior by increasing FI immediately before the start (Duve et al., 2011; Dalal, 2016) and after the end (Buyse et al., 1996; Svihus, 2014; Schwean-Lardner et al., 2016) of the fasting period. By this strategy, birds are able to extend the transit time of the digesta through the GIT to cope with the lack of feed availability during the FR (May and Lott, 1994; Svihus et al., 2013).

In experiment 1 , the crop content was measured immediately before the start of the fasting period to evaluate the ability of the birds to anticipate FI to the lack of feed availability. Compared with birds fed AL, the weight of the crop and its content increased linearly as the length of the FR period increased from 0 to $8 \mathrm{~h} / \mathrm{d}$, consistent with data of Duve et al. (2011) and Schwean-Lardner et al. (2013). Furthermore, the increase in the 
weight of the crop content was more intense when the subsequent FR period lasted for 6 h or more. Similarly, Shynkaruk et al. (2019) observed that the crop content of broilers exposed to dark for 4 to $10 \mathrm{~h} / \mathrm{d}$, reached a peak immediately before the start of the dark period, an effect that was not observed when the dark period lasted only for $1 \mathrm{~h}$. These results suggest that birds anticipate their feeding behavior by increasing FI prior to the expected lack of feed availability according to the length of the FR strategy, an effect that is more evident with $6 \mathrm{~h}$ or more of fasting.

In experiments 2 (essay 2) and 3, the content of the crop was measured 60 min after the end of the fasting period to evaluate the effect of the length of the FR on FI at the onset of the feeding period. In both experiments, an increase in the length of the fasting period from 4 to $8 \mathrm{~h} / \mathrm{d}$ in previously TR birds increased the content of the crop after the FR period. However, in experiment 2 (essay 2), training to fasting (restricted access to feed daily from 6 to $14 \mathrm{~d}$ of age vs. restricted access to feed only on d 14) altered the response of the birds to the length of the FR period. Independent of previous training, the crop content increased when the FR lasted for $6 \mathrm{~h}$ or more. However, compared to AL fed birds, $4 \mathrm{~h}$ of fasting increased the content of the crop in the TR but not in the NTR birds. In fact, after $4 \mathrm{~h}$ of fasting, the fresh and dry contents of the crop in the TR birds was 132 and 84\% greater, respectively, than the amount of digesta observed in the NTR birds. The lack of adaptation of the NTR birds to a FR period of only $4 \mathrm{~h}$, observed by the absence of content in the crop, might be attributed to the limited appetite of the bird after a short period without access to feed (Scanes et al., 1987; Classen et al., 2016). The data provided suggest that TR birds require shorter FR periods to adapt the storage capacity of the crop than NTR birds ( $\geq 4 \mathrm{~h}$ vs. $\geq 6 \mathrm{~h})$.

The storage of great amounts of feed in the crop is the main adaptive mechanism of the birds to face successfully the reduction in feed availability when subjected to long 
periods of FR (Buyse and Decuypere, 2003; Rodrigues and Choct., 2018). The release of the digesta from the crop to the next segments of the GIT determines the amount of nutrients available for bird digestion during the fasting period (Classen et al., 2016). Previous studies have reported variations in the retention time of the digesta in the crop when the fasting was applied by the manipulation of the light program. For example, Shires et al. (1987) reported that in broilers fed AL, the retention time of the digesta in the crop was approximately 7.4 min, exhibiting a low crop utilization. In contrast, Shynkaruk et al. (2019) observed that the crop was completely empty 2 and $6 \mathrm{~h}$ after the start of fasting at $27 \mathrm{~d}$ of age in birds trained to 4 and $10 \mathrm{~h} / \mathrm{d}$ of dark periods. Also, Buyse et al. (1993) reported some measurable digesta in the crop even at $5 \mathrm{~h}$ after the end of the light period in 32-d old broilers trained to $10 \mathrm{~h}$ of darkness. In experiment 2 (essay 3), the lowest digesta contents of the crop were observed in broilers fed AL, confirming that the retention time of the digesta in these birds is markedly low (Rodrigues and Choct, 2018). Under physical restriction of the access to feed, the RW of the fresh and dry contents of the crop were greater in TR than in NTR birds and increased as the length of the FR period increased from 0 to $8 \mathrm{~h}$. Furthermore, the retention time of the digesta in the crop depended on the length of the fasting period applied. In this respect, the contents of the crop disappeared from the organ at $2 \mathrm{~h}$ (broilers fasted for 4 and $6 \mathrm{~h}$ ) or $3 \mathrm{~h}$ (broilers fasted for $8 \mathrm{~h}$ ) after feed removal. The results indicate that FR alters the retention time of the digesta in the crop which in turn determines the amount of nutrients available for bird digestion during the fasting period (Classen et al., 2016). The data reported herein suggest that training on fasting improves the ability of broilers to adapt their feeding behavior to the FR conditions, with longer retention times of the digesta in the crop as the length of the fasting period increases. 
In experiment 2 (essay 3), gizzard contents were greater in TR than in NTR birds from 0 to $2 \mathrm{~h}$ after feed removal. However, even $4 \mathrm{~h}$ after feed deprivation, substantial amounts of digesta were still present in the gizzard, irrespective of the FR strategy used. In this respect, Buyse et al. (1993) and Shynkaruk et al. (2019) observed significant amounts of digesta present in the gizzard even $10 \mathrm{~h}$ after the end of the feeding period in broilers kept under $10 \mathrm{~h} / \mathrm{d}$ of darkness. Thompson and Applegate (2006) suggested that fasting for long periods (> $12 \mathrm{~h}$ ) might impair the integrity of the small intestine resulting from the lack of digesta content. The data reported herein, however, suggest that the rate of passage of the digesta from the gizzard to the duodenum decreased during fasting, a strategy that allows a more uniform supply of nutrients to the SI during the FR period. Probably, the greater amounts of feed stored in the crop of birds trained for fasting resulted in a prolonged flow of nutrients through the proximal part of the GIT facilitating the birds to cope with the subsequent period of lack of feed.

Longer residency times of the feed in the crop are associated with an improvement in the moisturization of the digesta, which in turn facilitates further nutrient utilization (Svihus et al., 2013). In experiments conducted by altering the length of the lighting period, both feed and water restriction start simultaneously (initiation of the dark period) and thus, the availability of feed and water is limited at the same time (Shynkaruk et al., 2019). However, when the access to feed is restricted by physical impediment, as occurred in the experiments comprised in this Doctoral Thesis, birds have no access to feed but water is freely available at all times. Consequently, before the start or after the end of the FR period, feeding activity is more important for these birds than drinking activity, with broilers giving preference to FI over water intake. In experiment 1 , the moisture content $(\%)$ of the crop digesta prior the start of the fasting period in the physical restricted birds was reduced because birds postponed drinking to eating behavior as water 
was available afterwards. In experiments 2 and 3, however, the increase in the length of the fasting period increased the amount of digesta stored in the crop but its moisture content remained unaltered. These results suggest that broilers increase both water intake and FI at a similar rate, probably as a strategy to ensure a proper moisturization of the digesta in the crop before the start of the digestion process in further segments of the GIT.

Longer retention times of the digesta in the crop are associated with more nutrients available for fermentation and with an increase in the activity of the microbiota present in this organ (Svihus et al., 2013; Classen et al., 2016). Consequently, a reduction in crop $\mathrm{pH}$ was expected as the length of the fasting period increased in the current research. In this respect, an increase in the length of the FR period from 4 to $8 \mathrm{~h} / \mathrm{d}$ tended to reduce crop pH. In experiments 1 and 2 (essay 2), however, the increase in FI observed immediately before the start and after the end of the fasting period resulted in an increase in the $\mathrm{pH}$ of the crop digesta compared to AL feeding. Probably, the greater FI observed in FR birds and the $\mathrm{pH}$ of the feed $(\mathrm{pH}=6.5)$ increased crop $\mathrm{pH}$ compared to AL fed birds, in which the digesta content in the crop was reduced. Nevertheless, in experiment 2 (essay 3), the progressive decrease in the amount of digesta remaining in the crop after feed removal resulted in a reduction in crop $\mathrm{pH}$. The data reported herein suggest that the fermentation activity in the crop increased with the time of residency of the digesta in this organ (Classen et al., 2016).

An increase in the length of the fasting period increased the number of Lactobacillus spp. colonies in the crop in experiments 1 and 3 . These results are in agreement with those reported by Dalal (2016) who observed that increasing the dark period from 1 to $11 \mathrm{~h} / \mathrm{d}$ tended to increase the number of Lactobacillus spp. colonies in the crop of broilers at $33 \mathrm{~d}$ of age. Furthermore, in experiment 3 , the colonization of the crop by Lactobacillus spp. with increasing lengths of the FR period resulted in an increase 
in the production of lactic acid in this organ. The information provided suggests that fasting promotes the colonization of the crop by Lactobacilli, a consequence of the increased amount of substrate available for fermentation, which in turn might facilitate further nutrient utilization (Svihus et al., 2013; Classen et al., 2016; Shynkaruk et al., 2019).

In the current research, the weight of the empty crop increased with the length of the FR period, with lowest values observed in broilers fed AL. Similar data have been reported by Dalal (2016) and Shynkaruk et al. (2019) in birds under light programs including dark periods of up to $10 \mathrm{~h} / \mathrm{d}$. In general, the implementation of the FR conditions improved crop development and storage capacity but had limited effects on gizzard traits. Similar lack of effects of fasting on gizzard development and size has been reported by Hoopaw and Goodman (1976) and Svihus et al. (2013). The gizzard is the main organ involved in the regulation of the rate of passage of the digesta from the proximal to the distal part of the GIT in AL fed birds (Jiménez-Moreno et al., 2009b; Svihus, 2011). However, the lack of effect observed on the influence of fasting on gizzard traits suggests that this organ has a minor role, compared to the crop, as a feed storage organ in birds subjected to FR conditions.

\subsubsection{Type of bird}

In modern broilers, a delay in the access to feed after hatch caused by a prolonged HW produces weight loss, dehydration, and stress of the chicks that are known to compromise growth during the first weeks of age (Willemsen et al., 2010; Jacobs et al., 2016). Furthermore, the reduction in FI capacity associated to these birds might alter broiler behavior (de Jong et al., 2017) and was expected to reduce the response of the broilers to fasting conditions. Similarly, the lower voracious behavior of Hubbard birds 
compared to birds selected for fast growth-rates (Ganzer et al. (2017); Steenfeldt et al., 2019) was expected to decrease the storage capacity of the crop and consequently, to reduce crop content at the onset of the feeding period. Nevertheless, the RW of the crop content 60 min after the end of the FR was not affected by broiler type, suggesting a similar adaptation of the storage function of the proximal part of the GIT in birds varying in potential capacity for FI.

The GIT of the birds is immature in newly hatched chicks but develops quickly during the first days of life (Jin et al., 1998; Sklan, 2001). However, a delay to the access to feed and water after hatch is frequently associated to a poor, retarded development of the digestive organs (Maiorka et al., 2003; El-Husseiny et al., 2008; Bhanja et al., 2009; van de Ven et al., 2013). In this respect, Cengiz et al. (2012) reported that at $10 \mathrm{~d}$ of age, the RW of the gizzard was lower in broilers fasted for $36 \mathrm{~h}$ after hatch compared to immediately fed broilers. In experiment 3, a delay in FI after hatch, resulting from an increase in the length of the HW from 24 to $48 \mathrm{~h}$, did not affect the RW of the organs of the GIT at 21 d of age. Similarly, Uni et al. (1998) and Geyra et al. (2001) observed a poor development of the SI of chicks that had a 36-h of delay in feed supply after hatch, compared to immediately fed chicks, but that most of the negative effects of the delay in the access to feed and water, disappeared after the first week of life. The information provided suggests that the effects of a delay in the access to feed after hatch, on the development of the organs of the GIT, are transitory and tend to disappear with age. However, the impact of a delay in GIT development of the birds might compromise digestion and absorption functions in the SI at older ages (de Jong et al., 2017).

In experiment 3 , the absolute weights of the crop and gizzard were heavier in Cobb than in Hubbard birds. In relative terms, however, organ weights did not differ between both bird strains. These results are in agreement with previous research (Mahagna and 
Nir, 1996; Zavarize et al., 2012; Kimiaeitalab et al., 2017;2018) reporting that differences in potential for growth among bird strains had little effect on relative organ weights. Gizzard pH, however, was higher in Hubbard birds than in Cobb birds, an effect that might have relevant consequences in further nutrient digestion (Svihus, 2011). Nir et al. (1994) and Sacranie et al. (2012) suggested that the $\mathrm{pH}$ of the gizzard varied according to digesta content. However, other factors, such as retention time of the digesta in the gizzard and hydrochloric secretion in the proventriculus, might vary between strains, affecting gizzard pH (Jiménez-Moreno et al., 2009b; Svihus, 2011). 
GENERAL CONCLUSIONS 


\section{GENERAL CONCLUSIONS}

1. The physical restriction of the access to feed for periods of $6 \mathrm{~h}$ or more might decrease feed consumption and impair feed conversion ratio in broilers for the first days after the implementation of the fasting strategy, with the potential negative effects decreasing quickly as the bird ages. However, no differences between feed restricted birds and ad libitum fed birds might be expected with shorter fasting periods $(4 \mathrm{~h})$.

2. In broilers fed ad libitum, the feed passes rapidly from the esophagus to the proventriculus and gizzard, suggesting that gizzard is the main organ regulating feed intake in these birds. Moderate increases in the length of the physical restriction of the access to feed (from 4 to $8 \mathrm{~h} / \mathrm{d}$ ), however, stimulate feed intake in broilers immediately before and after the fasting period by storing substantial amounts of feed in the crop. In contrast, feed restriction periods of up to $8 \mathrm{~h} / \mathrm{d}$ do not affect gizzard development in young broilers.

3. Broilers exhibit a fast adaptation of their feeding behavior to feed restriction and in fact, the birds are able to anticipate FI to the lack of feed availability as soon as $3 \mathrm{~d}$ after the start of the fasting conditions.

4. Training to the lack of access to feed stimulates the storage capacity of the crop and increases the retention time of the digesta in the proximal part of the gastrointestinal tract, helping the birds to face successfully the implementation of a feed restriction strategy. 
5. An excessive length of the hatching window (48 vs. $24 \mathrm{~h}$ ) results in a concomitant delay in the access to feed and water after hatch that reduces the body weight of the broilers at the arrival to the farm, which in turn might decrease feed intake and body weight gain during the first weeks of life. However, the potential impacts of an increase in the length of the hatching window on the development of the organs of the gastrointestinal tract are less evident.

6. Compared to modern broilers, genetic selection for strains with lower growth potential results in birds with poorer feed conversion ratio, a consequence of their lower feed intake capacity. However, the negative effects on growth performance associated to increases in the length of the feed restriction period might not differ among broiler strains varying in growth potential.

7. Independent of bird strain and hatching window, longer fasting periods stimulate the development of the crop and increase the number of Lactobacillus spp. colonies and the subsequent lactic acid concentration in this organ. These changes in crop environment can potentially benefit further nutrient digestion and improve the health status of the gastrointestinal tract of the birds. 


\section{REFERENCES}




\section{REFERENCES}

Abdollahi, M. R., F. Zaefarian, and V. Ravindran. 2018. Feed intake response of broilers: Impact of feed processing. Anim. Feed Sci. Tech. 237:154-165.

Abed, F., A. Karimi, Gh. Sadeghi, M. Shivazad, S. Dashti, and A. Sadeghi-Sefidmazgi. 2011. Do broiler chicks possess enough growth potential to compensate long-term feed and water depravation during the neonatal period? S. Afr. J. Anim. Sci. 41:3339.

Ahmed, S. T., M. M. Islam, H. S. Mun, H. J. Sim, Y. J. Kim, and C. J. Yang. 2014. Effects of Bacillus amyloliquefaciens as a probiotic strain on growth performance, cecal microflora, and fecal noxious gas emissions of broiler chickens. Poult. Sci. 93:1963-1971.

AOAC International. 2005. Official Methods of Analysis of the AOAC International. 18th ed. AOAC Int., Gaithersburg, United States of America.

Apeldoorn, E. J., J. W. Schrama, M. M. Mashaly, and H. K. Parmentier. 1999. Effect of melatonin and lighting schedule on energy metabolism in broiler chickens. Poult. Sci. 78:223-229.

ASAE. 2003. Method of determining and expressing fineness of feed materials by sieving. ASAE standard S319.2. Agriculture Engineers Yearbook of Standards. St. Joseph, MO.

Augère-Granier, M. L. 2019. The EU poultry meat and egg sector. Main features, challenges and prospects. European Parliamentary Research Service. DOI: 10.2861/33350. https://www.europarl.europa.eu/RegData/etudes/IDAN/2019/ 644195/EPRS_IDA(2019)644195_EN.pdf 
Ballay, M., E. A. Dunnington, B. W. Gross, and P. B. Siegel. 1992. Restricted feeding and broiler performance: age at initiation and length of restriction. Poult. Sci. $71: 440-447$.

Bhanja, S. K, C. A. Devi, A. K. Panda, and G. S. Sunder. 2009. Effect of post hatch heed deprivation on yolk-sac utilization and performance of young broiler chickens. Asian Austral. J. Anim. 22:1174-1179.

BOE (Boletín Oficial del Estado). 2013. Ley 53/2013 de 1 de febrero por el que se establecen las normas básicas aplicables para la protección de los animales utilizados en experimentación y otros fines científicos, incluyendo la docencia. BOE 34:11370-11421.

Bogosavljević-Bošković, S., S. Rakonjac, V. Dosković, and M. D. Petrović. 2012. Broiler rearing systems: a review of major fattening results and meat quality traits. World's Poult. Sci. J. 68:217-228.

Bomba, A., Z. Jonecova, S. Gancarcikova, and R. Nemcova. 2006. The gastrointestinal microbiota of farm animals. Gastrointestinal Microbiology. Pp. 381-399. A. C. Ouwehand, and E. E. Vaughan (Eds.) Informa Healthcare, London, United Kingdom.

Bowen, T.E., and P.W. Waldroup. 1969. The influence of propylene glycol on $\mathrm{pH}$ of the gastrointestinal tract and the incidence of leg abnormalities in broiler chicks. Poult. Sci. 48:608-613.

Brickett, K. E., J. P. Dahiya, H. L. Classen, C. B. Annett, and S. Gomis. 2007a. The impact of nutrient density, feed form, and photoperiod on the walking ability and skeletal quality of broiler chickens. Poult. Sci. 86:2117-2125. 
Brickett, K. E., J. P. Dahiya, H. L. Classen, and S. Gomis. 2007b. Influence of dietary nutrient density, feed form, and lighting on growth and meat yield of broiler chickens. Poult. Sci. 86:2172-2181.

Butzen, F. M., A. M. L. Ribeiro, M. M. Vieira, A. M. Kessler, J. C. Dadalt, and M. P. Della. 2013. Early feed restriction in broilers. I-Performance, body fraction weights, and meat quality. J. Appl. Poult. Res. 22:251-259.

Buys, N., J. Buyse. M. Hassanzadeh-Ladmakhi, and E. Decuypere. 1998. Intermittent lighting reduces the incidence of ascites in broilers: an interaction with protein content of feed on performance and the endocrine system. Poult. Sci. 77:54-61.

Buyse, J., D. S. Adelsohn, E. Decuypere, and C. G. Scanes. 1993. Diurnal-nocturnal changes in food intake, gut storage of ingesta, food transit time and metabolism in growing broiler chickens: A model for temporal control of energy balance. Br. Poult. Sci. 34:699-709.

Buyse, J., P. C. M. Simonsl, F. M. G. Boshouwers, and E. Decuypere. 1996. Effect of intermittent lighting, light intensity and source on the performance and welfare of broilers. World’s Poult. Sci. J. 52:121-130.

Buyse, J., and E. Decuypere. 2003. Feeding patterns in chickens: effects on endocrine and metabolic status. Proc. Aust. Poult. Sci. Symp., Sydney, Australia.

Buzala, M., B. Janicki, and R. Czarnecki. 2015. Consequences of different growth rates in broiler breeder and layer hens on embryogenesis, metabolism and metabolic rate: A review. Poult. Sci. 94:728-33.

Byrd, J. A., B. M. Hargis, D. J. Caldwell, R. H. Bailey, K. L. Herron, J. L. McReynolds, R. L. Brewer, R. C. Anderson, K. M. Bischoff, and T. R. Callaway. 2001. Effect of 
lactic acid administration in the drinking water during preslaughter feed withdrawal on Salmonella and Campylobacter contamination of broilers. Poult. Sci. 80:278283.

Camacho, M. A., M. E. Suarez, J. G. Herrera, J. M. Cuca, and C. M. Carcia-Bojalil. 2004. Effect of age of feed restriction and microelement supplementation to control ascites on production and carcass characteristics of broilers. Poult. Sci. 83:526-532.

Careghi, C., K. Tona, O. Onagbesan, J. Buyse, E. Decuypere, and V. Bruggeman. 2005. The effects of the spread of hatch and interaction with delayed feed access after hatch on broiler performance until seven days of age. Poult. Sci. 84:1314-1320.

Casteel, E., J. Wilson, R. Buhr, and J. Sander. 1994. The influence of extended posthatch holding time and placement density on broiler performance. Poult. Sci. 73:16791684.

Cengiz, O., B. H. Koksal, O. Tatli, O. Sevim, H. Avci, T. Epikmen, D. Beyaz, S. Buyukyoruk, M. Boyacioglu, A. Under, and A. G. Onol. 2012. Influence of dietary organic acid blend supplementation and interaction with delayed feed access after hatch on broiler growth performance and intestinal health. Vet. Med-Czech. $57: 515-528$.

Chaplin, S. B., J. Raven, and G. E. Duke. 1992. The influence of the stomach on crop function and feeding behaviour in domestic turkeys. Physiol. Behav. 52:261-266.

Cheema, M., M. Qureshi, and G. Havenstein. 2003. A comparison of the immune response of a 2001 commercial broiler with a 1957 randombred broiler strain when fed representative 1957 and 2001 broiler diets. Poult. Sci. 82:1519-1529. 
Classen, H. L., and C. Riddell. 1989. Photoperiodic effects on performance and leg abnormalities in broiler chickens. Poult. Sci. 68: 873-879.

Classen, H. L. 1992. Management factors of leg disorders. In: C. C. Whitehead (Ed.). Bone Biology and Skeletal Disorders in Poultry, pp. 195-211. Carfax Publishing Company, Abingdon, United Kingdom.

Classen, H. L., J. Apajalahti, B. Svihus, and M. Choct. 2016. The role of the crop in poultry production. World’s Poult. Sci. J. 72:459-472.

Cobb. 2018a. Cobb 500 Broiler Performance and Nutrition Supplement. L-2114-08. Cobb-Vantress-com. Colchester, United Kingdom.

Cobb. 2018b. Cobb 500 Broiler Management Guide. L-2114-08. Cobb-Vantress-com. Colchester, United Kingdom.

Cömert, M., Y. Şayan, F. Kırkpınar, Ö. H. Bayraktar, and S. Mert. 2016. Comparison of carcass characteristics, meat quality, and blood parameters of slow and fast grown female broiler chickens raised in organic or conventional production system. Asian. Austral. J. Anim. 29:987-997.

Corrier, D. E., J. A. Byrd, B. M. Hargis, M. E. Hume, R. H. Bailey, and L. H. Stanker. 1999a. Survival of Salmonella in the crop contents of market-age broilers during feed withdrawal. Avian Dis. 43:453-460.

Corrier, D. E., J. A. Byrd, B. M. Hargis, M. E. Hume, R. H. Bailey, and L. H. Stanker. 1999b. Presence of Salmonella in the crop and ceca of broiler chickens before and after preslaughter feed withdrawal. Poult. Sci. 78:45-49.

Council Directive 2007/43/EC. 2007. Laying down minimum rules for the protection of chickens kept for meat production. O. J. L. 182:19-28. 
Cutler, S. A., M. A. Rasmussen, M. J. Hensley, K. W. Wilhelms, R. W. Griffith, and C. G. Scanes. 2005. Effects of Lactobacilli and lactose on Salmonella typhimurium colonisation and microbial fermentation in the crop of the young turkey. Br. Poult. Sci. 46:708-716.

Dalal, S. 2016. Effect of photoperiod and dietary strategies on crop microbial ecology and health of broiler chickens. PhD Diss. Univ. Saskatchewan, Canada.

Decuypere, E., K. Tona, V. Bruggeman, and F. Bamelis. 2001. The day-old chick: a crucial hinge between breeders and broilers. World's Poult Sci. J. 57:127-138.

Denbow, D. M. 1989. Peripheral and central control of food-intake. Poult. Sci. 68:938947.

de Jong, I. C., J. Van Riel, A. Lourens, M. B. M. Bracke, and H. Van den Brand. 2016. Effects of food and water deprivation in newly hatched chickens. Wageningen Livestock Research, Report 999. Wageningen, The Netherlands.

de Jong, I. C., J. van Riel, M. B. M. Bracke, H. van den Brand. 2017. A `meta-analysis` of effects post-hatch food and water deprivation on development, performance and welfare of chickens. PLoS ONE 12:e0189350.

Duve, L. R., S. Steenfeldt, K. Thodberg, and B. L. Nielsen. 2011. Splitting the scotoperiod: effects on feeding behaviour, intestinal fill and digestive transit time in broiler chickens. Br. Poult. Sci. 52:1-10.

El-Husseiny, O. M, S. Abou El-Wafa, and H. M. A. El-Komy. 2008. Influence of fasting or early feeding on broiler performance. Int. J. Poult. Sci. 7:263-271. 
El-Sagheer, M., and M. Makled. 2005. Effect of duration of feed withdrawal versus ad libitum feeding during high environmental temperature on broiler chicken performance. Egypt. Poult. Sci. J. 25:333-350.

FAO, 2020. Accessed June. 2020. http://www.fao.org/faostat/en/

Farghly, M. F. A., K. M. Mahrose, A. E. Galal, R. M. Ali, E. A. M. Ahmad, Z. U. Rehman, Z. Ullah, and C. Ding. 2018. Implementation of different feed withdrawal times and water temperatures in managing turkeys during heat stress. Poult. Sci. 97:30763084.

Farghly, M. F., K. M. Mahrose, E. A. M. Ahmad, Z. U. Rehman, and S. Yu. 2019. Implementation of different feeding regimes and flashing light in broiler chicks. Poult. Sci. 98:2034-2042.

Farrell, D. 2013. The role of poultry in human nutrition. Poultry Development Review, FAO, Rome, Italy.

FEDNA (Fundación Española Desarrollo Nutrición Animal). 2018. Normas FEDNA para la Formulación de Piensos Compuestos. G. Santomá and G. G. Mateos (Eds). Fund. Esp. Desarro. Nutr. Anim., Madrid, Spain.

FEDNA (Fundación Española Desarrollo Nutrición Animal). 2019. Tablas de Composición y Valor Nutritivo de Alimentos para la Fabricación de Piensos Compuestos. 4th ed. In: C. De Blas, P. G. Rebollar, M. Gorrachategui, and G. G. Mateos (Eds). Fund. Esp. Desarro. Nutr. Anim., Madrid. Spain.

Ferket, P. R., and A. G. Gernat. 2006. Factors that affect feed intake of meat birds: A review. Int. J. Poult. Sci. 5:905-911. 
Fondevila, G., L. Cámara, J. L. Archs, and G. G. Mateos. 2018. Influence of feed form on performance and development of the proximal part of the gastrointestinal tract of broiler strains with different growth potential. Poultry Science Association 97 (E-Supplement 1):133 (Abstract 318).

Fonseca, B. B., M. E. Beletti, M. S. da Silva, P. L. da Silva, I. N. Duarte, and D. A. Rossi. 2010. Microbiota of the cecum, ileum morphometry, $\mathrm{pH}$ of the crop and performance of broiler chickens supplemented with probiotics. R. Bras. Zootec. 39:1756-1760.

Fuller, R. 1973. Ecological studies on the lactobacillus flora associated with the crop epithelium of the fowl. J. Appl. Microbiol. 36:131-139.

Fuller, R., and B. E. Brooker. 1974. Lactobacilli which attach to the crop epithelium of the fowl. Am. J. Clin. Nutr. 27:1305-1312.

Fuller, R. 1977. The importance of lactobacilli in maintaining normal microbial balance in the crop. British Poult. Sci. 18:85-94.

Gabriel, I., M. Lessire, S. Mallet, and J. F. Guillot. 2006. Microflora of the digestive tract: critical factors and consequences for poultry. World’s Poult. Sci. J. 62: 499-511.

Ganzer, C., W. Siegert, H. Kluth, J. Bennewitz, and M. Rodehutscord. 2017. Prececal amino acid digestibility of soybean cake in fast and slow-growing broiler chickens. Poult. Sci. 96:2804-2810.

Geyra, A., Z. Uni, and D. Sklan. 2001. The effect of fasting at different ages on growth and tissue dynamics in the small intestine of the young chick. Brit. J. Nutr. 86:5361. 
González-Alvarado, J. M., E. Jiménez-Moreno, D. G. Valencia, R. Lázaro, and G. G. Mateos. 2008. Effects of fiber source and heat processing of the cereal on the development and ph of the gastrointestinal tract of broilers fed diets based on corn or rice. Poult. Sci. 87:1779-1795.

Guèye, E. F. 1998. Poultry plays an important role in African village life. World Poultry $14: 14-17$.

Havenstein, G. B., P. R. Ferket, and M. A. Qureshi. 2003. Growth, livability, and feed conversion of 1957 versus 2001 broilers when fed representative 1957 and 2001 broiler diets. Poult. Sci. 82:1500-1508.

Hilmi, H. T. A., A. Surakka, J. Apajalahti, and P. E. J. Saris. 2007. Identification of the most abundant Lactobacillus species in the crop of 1-and 5-week-old broiler chickens. Appl. Environ. Microbiol. 73:7867-7873.

Hinton, A., R. J. Buhr, and K. D. Ingram. 2000a. Physical, chemical, and microbiological changes in the crop of broiler chickens subjected to incremental feed withdrawal. Poult. Sci. 79: 212-218.

Hinton, A., R. J. Buhr, and K. D. Ingram. 2000b. Reduction of Salmonella in the crop of broiler chickens subjected to feed withdrawal. Poult. Sci. 79: 1566-1570.

Hoffmann, I. 2005. Research and investment in poultry genetic resources-challenges and options for sustainable use. World's Poult. Sci. J. 61:57-70.

Hooppaw, P. D, and B. L. Goodman. 1976. The influence of intermittent light on growth performance and other traits in young chicks. Poult. Sci. 55:2285-2289. 
Hubbard. 2016a. Broiler JA757, performance objectives. Hubbard LLC. Pikeville, United States of America. https://www.hubbardbreeders.com/products/crosses/cat/ premium-non-recessive/fast-growth/ 7931-ja757.html.

Hubbard. 2016b. Broiler Redbro, performance objectives. Hubbard LLC. Pikeville, United States of America. https://www.hubbardbreeders.com/products/crosses/cat/ premium-recessive/differenciated-growth/7953-redbro-m.html

Hunton, P. 2006. 100 years of poultry genetics. World's Poult. Sci. J. 62:417-428.

Jackson, S., and G. E. Duke. 1995. Intestine fullness influences feeding behaviour and crop filling in the domestic turkey. Physiol. Behav. 58:1027-1034.

Jacobs, L., E. Delezie, L. Duchateau, K. Goethals, B. Ampe, E. Lambrecht, X. Gellynck, and F. A. M. Tuyttens. 2016. Effect of post-hatch transportation duration and parental age on broiler chicken quality, welfare, and productivity. Poult. Sci. 95:1973-1979.

Jiménez-Moreno, E., J. M. González-Alvarado, A. de Coca-Sinova, R. Lázaro, and G.G. Mateos. 2009a. Effects of source of fiber on the development and $\mathrm{pH}$ of the gastrointestinal tract of broilers. Anim. Feed Sci. Technol. 154:93-101.

Jiménez-Moreno, E., J. M. González-Alvarado, R. Lázaro, and G. G. Mateos. 2009b. Effects of type of cereal, heat processing of the cereal, and fiber inclusion in the diet on gizzard $\mathrm{pH}$ and nutrient utilization in broilers at different ages. Poult. Sci. 88:1925-1933.

Jiménez-Moreno, E., A. de Coca-Sinova, J. M. González-Alvarado, and G. G. Mateos. 2016. Insoluble fiber sources in mash or pellet diets for young broilers. 1. Effects on growth performance and water intake. Poult. Sci. 95:41-52. 
Jiménez-Moreno, E., J. M. González-Alvarado, A. de Coca-Sinova, R. P. Lázaro, L. Cámara, and G. G. Mateos. 2019. Insoluble fiber sources in mash or pellets diets for young broilers. 2. Effects on gastrointestinal tract development and nutrient digestibility. Poult. Sci. 98:2531-2547.

Jin, S. H., A. Corless, and J. Sell. 1998. Digestive system development in post-hatch poultry. World's Poult. Sci. J. 54:335-345.

Jozefiak, D., A. Rutkowski, B. B. Jensen, and R. M. Engberg. 2006. The effect of betaglucanase supplementation of barley- and oatbased diets on growth performance and fermentation in broiler chicken gastrointestinal tract. Br. Poult. Sci. 47:57-64.

Ketelaars, E. H., M. Verbrugge, W. Van Der Hel, J. M. Van De Linden, and W. M. A. Verstegen. 1986. Effect of intermittent lighting on performance and energy metabolism of broilers. Poult. Sci. 65:2208-2213.

Kimiaeitalab, M. V., L. Cámara, S. Mirzaie Goudarzi, E. Jiménez-Moreno, and G. G. Mateos. 2017. Effects of the inclusion of sunflower hulls in the diet on growth performance and digestive tract traits of broilers and pullets fed a broiler diet from zero to $21 \mathrm{~d}$ of age. A comparative study. Poult. Sci. 96:581-592.

Kimiaeitalab, M. V., S. Mirzaie Goudarzi, E. Jiménez-Moreno, L. Cámara, and G. G. Mateos. 2018. A comparative study on the effects of dietary sunflower hulls on growth performance and digestive tract traits of broilers and pullets fed a pullet diet from 0 to 21 days of age. Anim. Feed Sci. Technol. 236:57-67.

Leeson, S. 1986. Nutritional considerations of poultry during heat stress. World's Poult. Sci. J. 42:69-81. 
Leeson, S., L. Caston, and J. D. Summers. 1996. Broiler response to energy or energy and protein dilution in the finisher diet. Poult. Sci. 75:522-528.

Leeson, S., L. J. Caston, and J. D. Summers. 1999. Performance of male broilers to 70 days when fed diets of varying nutrient density as mash or pellets. J. Appl. Poult. Res. 8:452-464.

Lewis, P. D., T. R. Morris, and G. C. Perry. 1996. Lighting and mortality rates in domestic fowl. Br. Poult. Sci. 37:295-300.

Lewis, P. D., G. C. Perry, L. J. Farmer, and R. L. S. Patterson. 1997. Responses of two genotypes of chicken to the diets and stocking densities typical of UK and 'Label Rouge' production systems: Performance, behaviour and carcass composition. Meat Sci. 45:501-516.

Lewis, P., and T. Morris. 2006. Poultry Lighting: the Theory and Practice. Northcot, Hampshire, United Kingdom.

Lewis, P. D., and R. Gous. 2007. Broilers perform better on short or step-up photoperiods. S. Afr. J. Anim. Sci. 37:90-96.

Lewis, P. D., R. Danisman, and R. M. Gous. 2009. Photoperiodic responses of broilers. I. Growth, feeding behaviour, breast meat yield, and testicular growth. Br. Poult. Sci. 50:657-666.

Lewis, P. D., R. Danisman, and R. M. Gous. 2010. Welfare-compliant lighting regimens for broilers. Arch. Gerflügelk. 74:265-268.

Lien, R. J., Hess, J. B., McKee, S. R., Bilgili, S. F., and Townsend, J. C. 2007. Effect of light intensity and photoperiod on live performance, heterophil-to-lymphocyte ration, and processing yields of broilers. Poult. Sci. 86:1287-1293. 
Lilburn, M. S. 1994. Skeletal growth of commercial poultry species. Poult. Sci. 73:897903.

Littell, R. C., P. R. Henry, and C. B. Ammerman. 1998. Statistical analysis of repeated measures data using SAS procedures. J. Anim. Sci. 76:1216-1231.

Livingston, M. L., C. Landon, H. J. Barnes, and J. Brake. 2019. White striping and wooden breast myopathies of broiler breast muscle is affected by time-limited feeding, genetic background, and egg storage. Poult. Sci. 98:217-226.

López, G., and S. Leeson. 2005. Utilization of metabolizable energy by young broilers and birds of intermediate growth rate. Poult. Sci. 84:1069-1076.

Lott, B. D., S. L. Branton, and J. D. May. 1996. The effect of photoperiod and nutrition on ascites incidence in broilers. Avian Dis. 40:788-791.

Mahagna, M., and I. Nir. 1996. Comparative development of digestive organs, intestinal disaccharidases and some blood metabolites in broiler and layer-type chicks after hatching. Br. Poult. Sci. 37:359-371.

Maiorka, A., E. Santin, F. Dahlke, I. C. Boleli, R. L. Furlan, and M. Macari. 2003. Posthatching water and feed deprivation affect the gastrointestinal tract and intestinal mucosa development of broiler chicks. J. Appl. Poult. Res. 12:483-492.

Mateos, G. G., E. Jimenez-Moreno, M. P. Serrano, and R. Lázaro. 2012. Poultry response to high levels of dietary fiber sources varying in physical and chemical characteristics. J. Appl. Poult. Res. 21:156-174.

Mateos, G. G., G. Fondevila, and L. Cámara. 2019. The importance of the fibre fraction of the feed in non-ruminant diets. The Value of Fibre. Engaging the Second Brain for Animal Nutrition. G. González-Ortiz, M.R. Bedford, K.E. Bach Knudsen, C.M. 
Courtin, and H.L. Classen (Eds.) Wageningen Academic Publishers, Wageningen, The Netherlands.

May, J. D., and B. D. Lott. 1992. Effect of periodic feeding and photoperiod on anticipation of feed withdrawal. Poult. Sci. 71:951-958.

May, J. D., and B. D. Lott. 1994. Effects of light and temperature on anticipatory feeding by broilers. Poult. Sci. 73:1398-1403.

Mottet, A., and G. Tempio. 2017. Global poultry production: current state and future outlook and challenges. World's Poult. Sci. J. 73:245-256.

Mussini, F. J. 2012. Comparative response of different broiler genotypes to dietary nutrient levels. PhD Diss. Univ. Arkansas, United States of America.

Nielsen, B. L., M. Litherland, and F. Nøddegaard. 2003. Effects of qualitative and quantitative feed restriction on the activity of broiler chickens. Appl. Anim. Behav. Sci. 83:309-323.

Noy, Y., and D. Sklan. 1999. Energy utilization in newly hatched chicks. Poult. Sci. 78:1750-1756.

OECD-FAO, 2018. OECD-FAO Agricultural Outlook 2018-2027. Rome, Italy. Accessed June 2020.

Ohtani, S., and S. Leeson. 2000. The effect of intermittent lighting on metabolizable energy intake and heat production of male broilers. Poult. Sci. 79:167-171.

Olanrewaju, H. A., J. P. Thaxton, W. A. Dozier, J. Purswell, W. B. Roush, and S. L. Branton. 2006. A review of lighting programs for broiler production. Int. J. Poult. Sci. 5:301-308. 
Olanrewaju, H. A., W. W. Miller, W. R. Maslin, S. D. Collier, J. L. Purswell, and S. L. Branton. 2015. Influence of photoperiod, light intensity and their interaction on health indices of modern broilers grown to heavy weights. Int. J. Poult. Sci. 14:183190.

Olkowski, A. A. 2007. Pathophysiology of heart failure in broiler chickens: structural, biochemical, and molecular characteristics. Poult. Sci. 86:999-1005.

Onbaşilar, E. E., H. Erol, Z. Cantekin, and U. Kaya. 2007. Influence of intermittent lighting on broiler performance, incidence of tibial dyschondroplasia, tonic immobility, some blood parameters and antibody production. Asian. Austral. J. Anim. 20:550-555.

Özkan, S., Y. Akbaş, Ö. Altan, A. Altan, V. Ayhan, and K. Özkan. 2003. The effect of short-term fasting on performance traits and rectal temperature of broilers during the summer season. Br. Poult. Sci. 44:88-95.

Özlü, S., R. Shiranjang, O. Elibol, and J. Brake. 2018. Effect of hatching time on yolk sac percentage and broiler live performance. Braz. J. Poult. Sci. 20:231-236.

Philips, S. M., and R. Fuller. 1983. The activities of amylase and a trypsin-like protease in the gut contents of germ-free and conventional chickens. Br. Poult. Sci. 24:115121.

Pinchasov, Y., and Y. Noy. 1993. Comparison of post-hatch holding time and subsequent early performance of broiler chicks and turkey poults. Br. Poult. Sci. 34:111-120.

Plavnik, I., and S. Hurwitz. 1985. The performance of broiler chicks during and following a severe feed restriction at an early age. Poult. Sci. 64:348-355. 
Pritchard, P. J. 1972. Digestion of sugars in the crop. Comp. Biochem. Physiol. 43:195205.

Rambau, M. D., M. L. Mudau, S. D. Makhanya, and K. Benyi. 2016. Effects of stocking density and daily feed withdrawal periods on the performance of broiler chickens in a semi-arid environment. Trop. Anim. Health Prod. 48:1547-1554.

Rath, N. C., G. R. Huff, W. E. Huff, and J. M. Balog. 2000. Factors regulating bone maturity and strength in poultry. Poult. Sci. 79:1024-1032.

Rauw, W. M., E. Kanis, E. N. Noordhuizen-Stassen, and F. J. Grommers. 1998. Undesirable side effects of selection for high production efficiency in farm animals: a review. Livest. Prod. Sci. 56:15-33.

Ravindran, V., Y. B. Wu, D. G. Thomas, and P. C. Morel. 2006. Influence of whole wheat feeding on the development of gastrointestinal tract and performance of broiler chickens. Aust. J. Agr. Res. 57:21-26.

Richards, M. P. 2003. Genetic regulation of feed intake and energy balance in poultry. Poult. Sci. 82:907-916.

Richards, M. P., R. W. Rosebrough, C. N. Coon, and J. P. McMurtry. 2010. Feed intake regulation for the female broiler breeder: In theory and in practice. J. Appl. Poult. Res. 19:182-193.

Ristić, M. 2003. Fleishqualität von broiler aus der ökologischer produktion. Biotechnol. Anim. Husb. 19:335-343.

Robinson, F. E., H. L. Classen, J. A. Hanson, and D. K. Onderka. 1992. Growth performance, feed efficiency and the incidence of skeletal and metabolic disease in 
full-fed and feed restricted broiler and roaster chickens. J. Appl. Poult. Res. 1:3341.

Rodrigues, I., and M. Choct. 2018. The foregut and its manipulation via feeding practices in the chicken. Poult. Sci. 97:3188-3206.

Rodrigues, I., and M. Choct. 2019. Feed intake pattern of broiler chickens under intermittent lighting: Do birds eat in the dark? Anim. Nutr. 5:174-178.

Ross. 2018. Ross Broiler Management Handbook. L-2114-08. Aviagen, Hutsville, United States of America.

Sacranie, A., B. Svihus, V. Denstadli, B. Moen, P. A. Iji, and M. Choct. 2012. The effect of insoluble fiber and intermittent feeding on gizzard development, gut motility, and performance of broiler chickens. Poult. Sci. 91:693-700.

Sahraei, M. 2012. Feed restriction in broiler chickens production: a review. Glob. Vet. $8: 449-458$.

Sahraei, M. 2014. Effects of feed restriction on metabolic disorders in broiler chickens: A review. Biotechnol. Anim. Husb. 30:1-13.

SAS Institute. 2018. SAS/STAT 15.1 User's Guide. SAS Institute Inc., Cary, N.C.

Savory, C. J. 1980. Diurnal feeding patterns in domestic fowls: a review. Appl. Anim. Ethol. 6: 71-82.

Savory, C. J. 1985. An investigation into the role of the crop in control of feeding in Japanese quail and domestic fowls. Physiol. Behav. 35:917-928.

Savory, C. J. 1999. Temporal control of feeding behaviour and its association with gastrointestinal function. J. Exp. Zool. 283:339-347. 
Scheele, C. W. 1997. Pathological changes in metabolism of poultry related to increasing production levels. Vet. Q. 19:127-130.

SCAHAW. 2000. European Commission - Scientific Committee on Animal Health and Animal Welfare. The welfare of Chickens Kept for Meat Production (Broilers). European Commission, Brussels, Belgium. Adopted 21 March 2000.

Scanes, C. G., R. Campbell, and P. Griminger. 1987. Control of energy balance during egg production in the laying hen. J. Nutr. 117:605-611.

Schwean-Lardner, K., B. I. Fancher; H. L. Classen. 2012. Effect of daylength on the productivity of two commercial broiler strains. Br. Poult. Sci. 53:7-18.

Schwean-Lardner, K., B. I. Fancher, S. Gomis, A. Van Kessel, S. Dalal, and H. L. Classen. 2013. Effect of day length on cause of mortality, leg health, and ocular health in broilers. Poult. Sci. 92:1-11.

Schwean-Lardner, K., B. I. Fancher, B. Laarvelda, and H. L. Classen. 2014. Effect of day length on flock behavioural patterns and melatonin rhythms in broilers. Br. Poult. Sci. 55:21-30.

Schwean-Lardner, K., C. Vermette, M. Leis, and L. Classen. 2016. Basing turkey lighting programs on broiler research: a good idea? A comparison of 18 daylength effects on broiler and turkey welfare. Animals 6:27-43.

Serrano, M. P., D. G. Valencia, J. Méndez, and G. G. Mateos. 2012. Influence of feed form and source of soybean meal of the diet on growth performance of broilers from 1 to 42 days of age. 1. Floor pen study. Poult. Sci. 91:2838-2844. 
Serrano, M. P., M. Frikha, J. Corchero, and G. G. Mateos. 2013. Influence of feed form and source of soybean meal on growth performance, nutrient retention, and digestive organ size of broilers. 2. Battery study. Poult. Sci. 92:693-708.

Shires, A., J. R. Thompson, B. V. Turner, P. M. Kennedy, and Y. K. Goh. 1987. Rate of passage of corn-canola meal and corn-soybean meal diets through the gastrointestinal tract of broiler and White Leghorn chickens. Poult. Sci. 66:289298.

Shynkaruk, T., H. L. Classen, T. G. Crowe, and K. Schwean-Lardner. 2019. The impact of dark exposure on broiler feeding behavior and weight of gastrointestinal tract segments and contents. Poult. Sci. 98:2448-2458.

Sklan, D. 2001. Development of the digestive tract of poultry. World Poult. Sci. J. 57:415428.

Smith, M.O., and R. G. Teeter. 1988. Practical application of potassium chloride and fasting during naturally occurring summer heat stress. Poult. Sci. 67 (Suppl.1):36.

Soutyrine, A. G., M. O. Smith, and B. Sivanadian. 1998. Feed withdrawal, potassium chloride, and carbonated water effects on broiler thermotolerance. J. Appl. Poult. Res. 7:138-143.

Squibb, R. L., and G. H. Collier. 1979. Feeding behaviour of chicks under three lighting regimens. Poult. Sci. 58:641-645.

Steenfeldt, S., P. Sørensen, and B. L. Nielsen. 2019. Effects of choice feeding and lower ambient temperature on feed intake, growth, foot health, and panting of fast- and slow-growing broiler strains. Poult. Sci. 98:503-513. 
Svihus, B., and H. Hetland. 2001. Ileal starch digestibility in growing broiler chickens fed on a wheat-based diet is improved by mash feeding, dilution with cellulose or whole wheat inclusion. Br. Poult. Sci. 42:633-637.

Svihus, B. 2010a. Effect of digestive tract conditions, feed processing and ingredients on response to NSP enzymes. Enzymes in Farm Animal Nutrition. Pp. 4301-4310. M. R. Bedford, and G. G. Partridge (Eds.) CAB International, Wallingford, United Kingdom.

Svihus, B., A. Sacranie, V. Denstadli, and M. Choct. 2010b. Nutrient utilization and functionality of the anterior digestive tract caused by intermittent feeding and inclusion of whole wheat in diets for broiler chickens. Poult. Sci. 89:2617-2625.

Svihus, B. 2011. The gizzard: function, influence of diet structure and effects on nutrient availability. World’s Poult. Sci. J. 67:207-224.

Svihus, B., V. B. Lund, B. Borjgen, M. R. Bedford, and M. Bakken. 2013. Effect of intermittent feeding, structural components and phytase on performance and behaviour of broiler chickens. Br. Poult. Sci. 54:222-230.

Svihus, B. 2014. Function of the digestive system. J. Appl. Poult. Res. 23:306-314.

Tannock, G. W. 2004. A special fondness for lactobacilli. Appl. Environ. Microbiol. 70:3189-3194.

Teeter, R., M. O. Smith, S. Sangiah, and F. B. Mather. 1987. Effects of feed intake and fasting duration upon body temperature and survival of thermostressed broilers. Nutr. Rep. Int. 35:531-537.

Thompson, K. L., and T. J. Applegate. 2006. Feed withdrawal alters small-intestinal morphology and mucus of broilers. Poult. Sci. 85:1535-1540. 
Tong, Q., T. Demmers, C. E. B. Romanini, H. Bergoug, N. Roulston, V. Exadaktylos, C. Bahr, D. Berckmans, M. Guinebretière, N. Eterradossi, P. Garain, and I. M. McGonnell. 2015. Physiological status of broiler chicks at pulling time and the relationship to duration of holding period. Animal 9:1181-1187.

Uni, Z., S. Ganot, and D. Sklan. 1998. Posthatch development of mucosal function in the broiler small intestine. Poult. Sci. 77:75-82.

Uni, Z., and R. P. Ferket. 2004. Methods for early nutrition and their potential. World's Poult. Sci. J. 60:101-111.

USDA-NASS (United States Department of Agriculture - National Agricultural Statistics Service). 2016. Certified organic survey 2015 summary. Washington, United States of America.

van de Ven, L. J. F., A. V. van Wagenberg, E. Decuypere, B. Kemp, and H. van den Brand. 2013. Perinatal broiler physiology between hatching and chick collection in 2 hatching systems. Poult. Sci. 92:1050-1061.

Van Horne, P. L .M., and T. J. Achterbosch. 2008. Animal welfare in poultry production systems: impact of EU standards on world trade. World's Poult. Sci. J. 64:40-52.

Van Soest, P. J., J. B. Robertson, and A. Lewis. 1991. Methods for dietary fiber, neutral detergent fiber, and non-starch polysaccharides in relation to animal nutrition. J. Dairy Sci. 74:3583-3597.

Willemsen, H., M. Debonne, Q. Swennen, N. Everaert, C. Careghi, H. Han, V. Bruggeman, K. Tona, and E. Decuypere. 2010. Delay in feed access and spread of hatch: importance of early nutrition. World's Poult. Sci. J. 66:177-188. 
Yu, M. W., and F. E. Robinson. 1992. The application of short-term feed restriction to broiler chicken production: a review. J. Appl. Poult. Res. 1:147-153.

Zavarize, K. C., J. R. Sartori, E. Gonzales, and A. C. Pezzato. 2012. Morphological changes of the intestinal mucosa of broilers and layers as affected by fasting before sample collection. Braz. J. Poult. Sci. 14:21-25.

Zhan, X. A., M. Wang, H. Ren, R. Q. Zhao, J. X. Li, and Z. L. Tan. 2007. Effect of early feed restriction on metabolic programming and compensatory growth in broiler chickens. Poult. Sci. 86: 654-660.

Zuidhof, M. J., B. L. Schneider, V. L. Carney, D. R. Korver, and F. E. Robinson. 2014. Growth, efficiency, and yield of commercial broilers from 1957, 1978, and 2005. Poult. Sci. 93:2970-2982. 